\title{
Life Cycle Environmental Assessment of Lithium-Ion and Nickel Metal Hydride Batteries for Plug-in Hybrid and Battery Electric Vehicles. Supporting Information
}

\author{
Guillaume Majeau-Bettez*, Troy R. Hawkins and Anders Hammer Strømman \\ Industrial Ecology Programme, Norwegian University of Science and Technology (NTNU), \\ Høgskoleringen 5, NO-7491 Trondheim, Norway
}

*Corresponding author. Email: guillaume.majeau-bettez@ntnu.no

\section{Table of Contents}

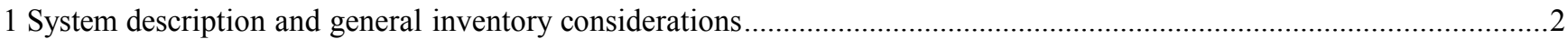

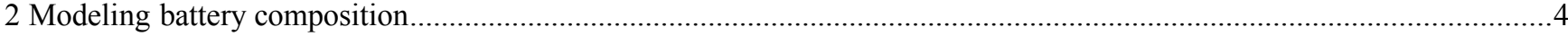

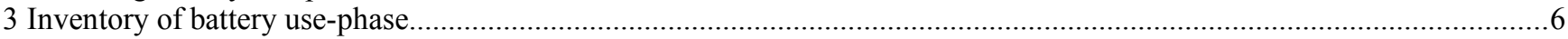

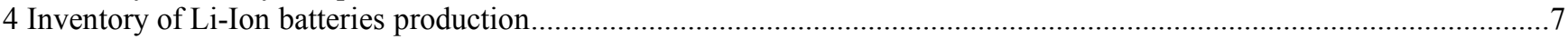

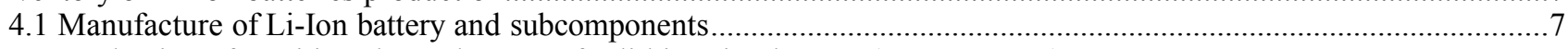

4.2 Production of positive electrode pastes for lithium ion battery (NCM or LFP) ................................................... 8

4.3 Production of negative electrode paste of lithium ion battery (NCM or LFP) ..........................................................

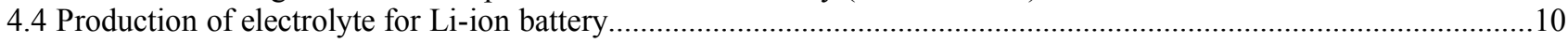

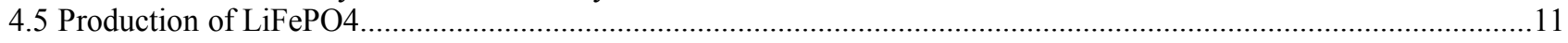

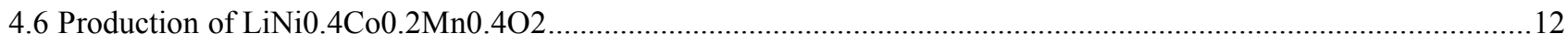

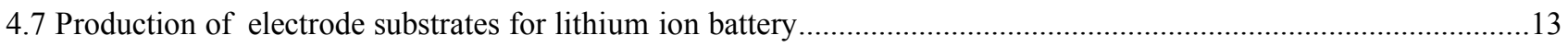

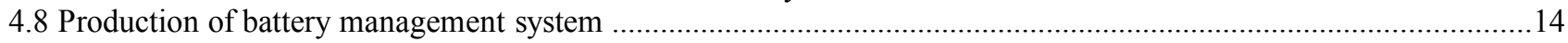

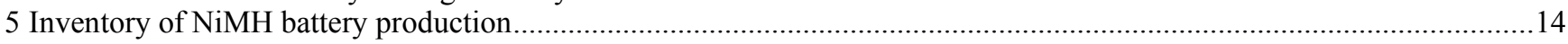

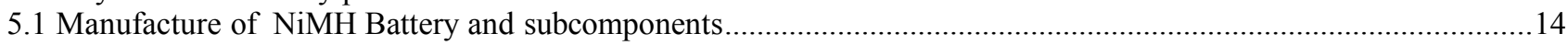

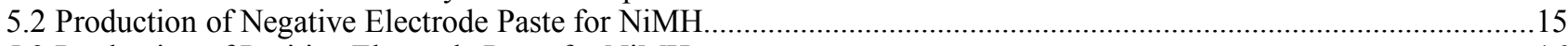

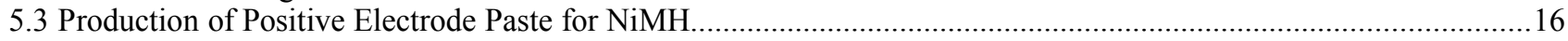

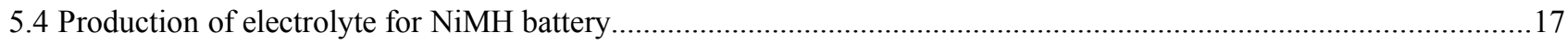

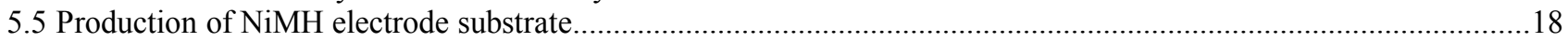

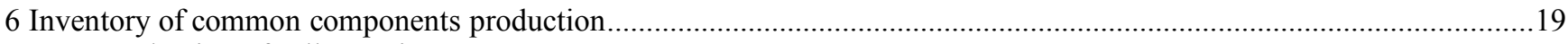

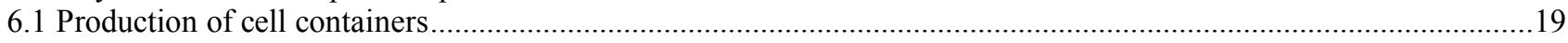

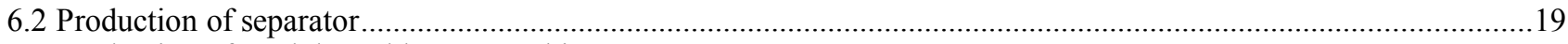

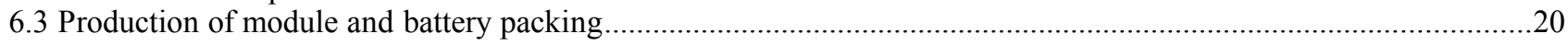

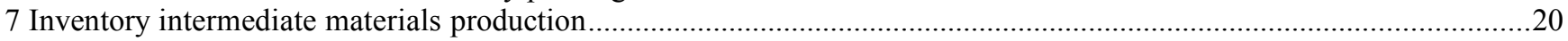

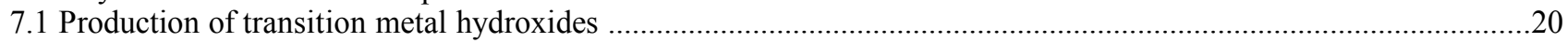

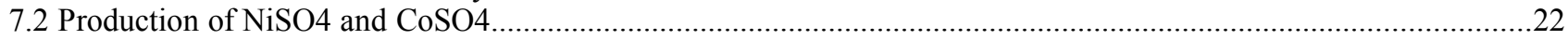

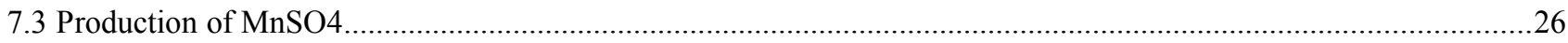

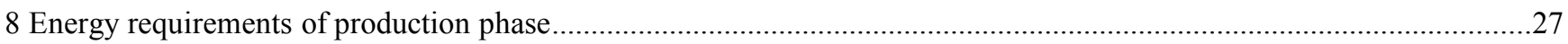

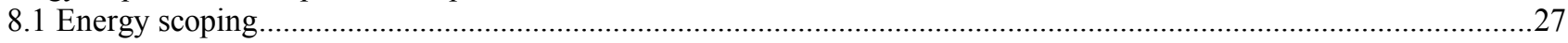

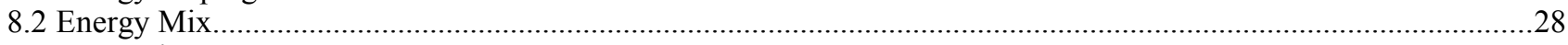

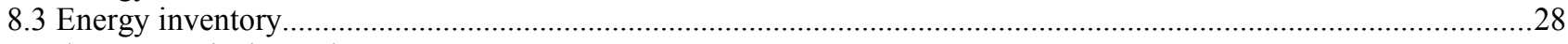

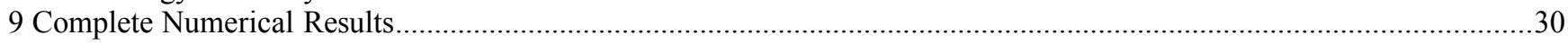

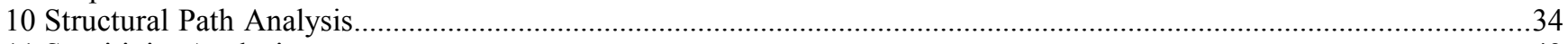

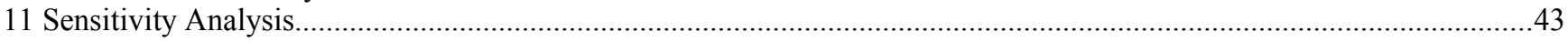

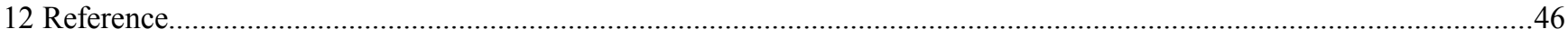




\section{System description and general inventory considerations}

Figure S1a presents our battery system, defined by the delivery of $50 \mathrm{MJ}$ of electrical energy to the power-train. The production chains of the the different electrode pastes batteries were inventoried as presented in Figure S1b-f. Unless otherwise specified, the different process descriptions assume average European conditions. This choice is motivated by a greater data availability. Except for the final delivery of the battery, the transportation requirements were all based on standard transportation distances formaterials consumed in Europe, as reported in Ecoinvent (1). The infrastructure requirements of this inventory were all assessed with proxies from Ecoinvent. 

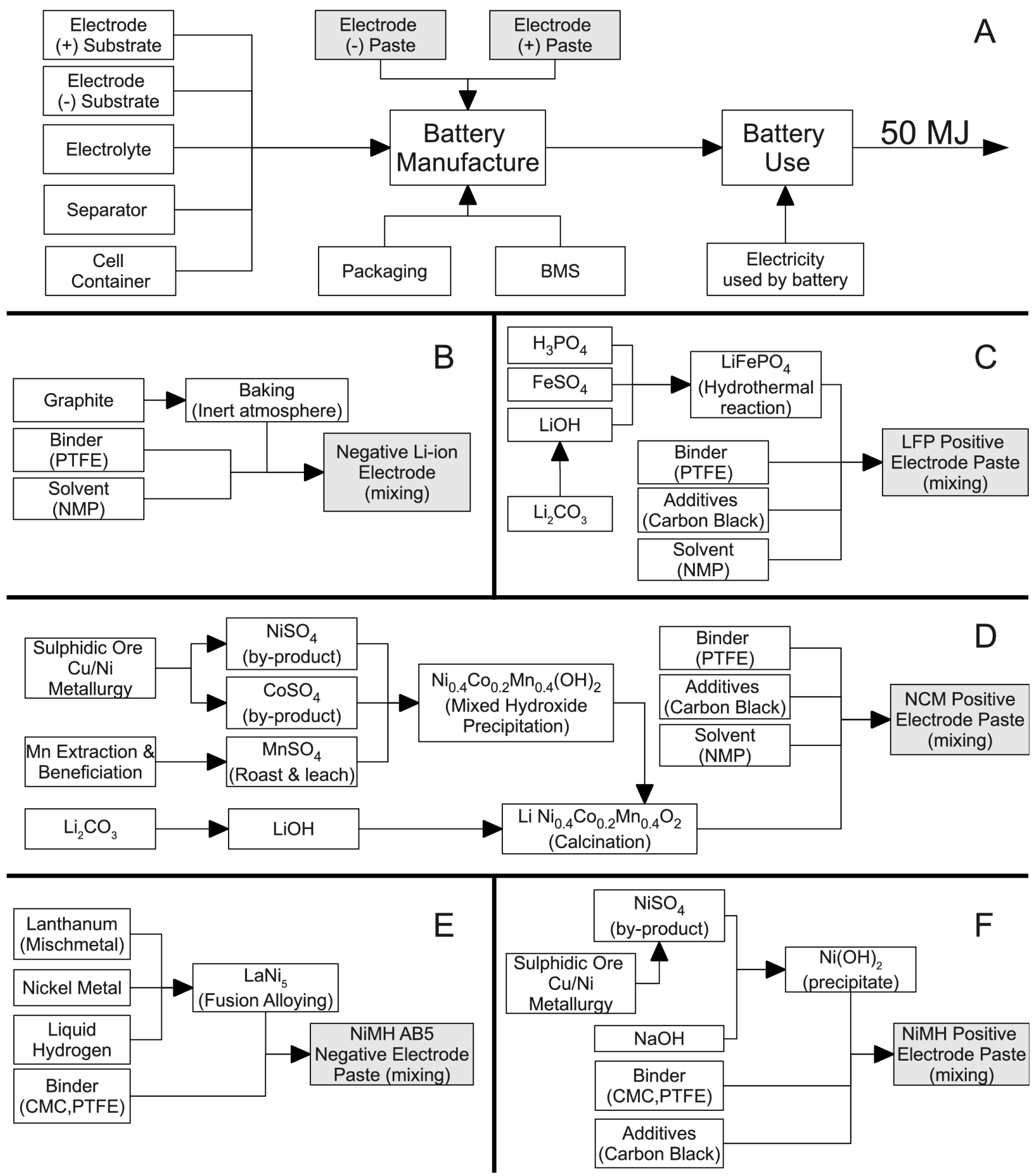

Figure S1. General flow diagram of the FU and battery system (a), along with detailed flow diagrams of the different electrode pastes (b-f). The different electrode pastes are highlighted in gray. Abbreviations: BMS refers to "battery management system", CMC to carboxymethyl cellulose, NMP to N-methylpyrrolidinone, and PTFE to polytetrafluoroethylene. 


\section{Modeling battery composition}

The energy density of a cell is function of its mass share of electrochemically active material. However, for fast charge and discharge currents (high power), the layer of the electrode material on the current collectors should be as thin as possible. Greater power density is thus achieved by batteries with smaller proportions of chemically active material and larger proportions of "supporting components", as illustrated by the Ragone plot $(2,3)$. The share of the battery mass embodied as electrode materials, electrode substrates, separators, and containers can vary by 3-4 folds between a high-power and a highenergy battery (4) .

To model the three batteries of this study, we reconciled material electrochemical properties (specific capacity and voltage), battery dismantling inventories, and expected typical battery performances. Figure S2 illustrates the procedure followed to produce our three inventories (Table S1). First, a certain "packaging factor" had to be assumed (Figure S2, step a). The different scenarios put forth by Axsen et al. (5) present mass fractions of $25 \%$ or $16 \%$ for non-cell components, while Gaines and Nelson (6) report values of approximately 13\%. Our model assumes $17 \%$ of the battery mass as packaging, plus $3 \%$ for the battery management system (BMS) for Li-ion batteries. This does not include any cooling system, which we consider to be beyond our system boundaries.

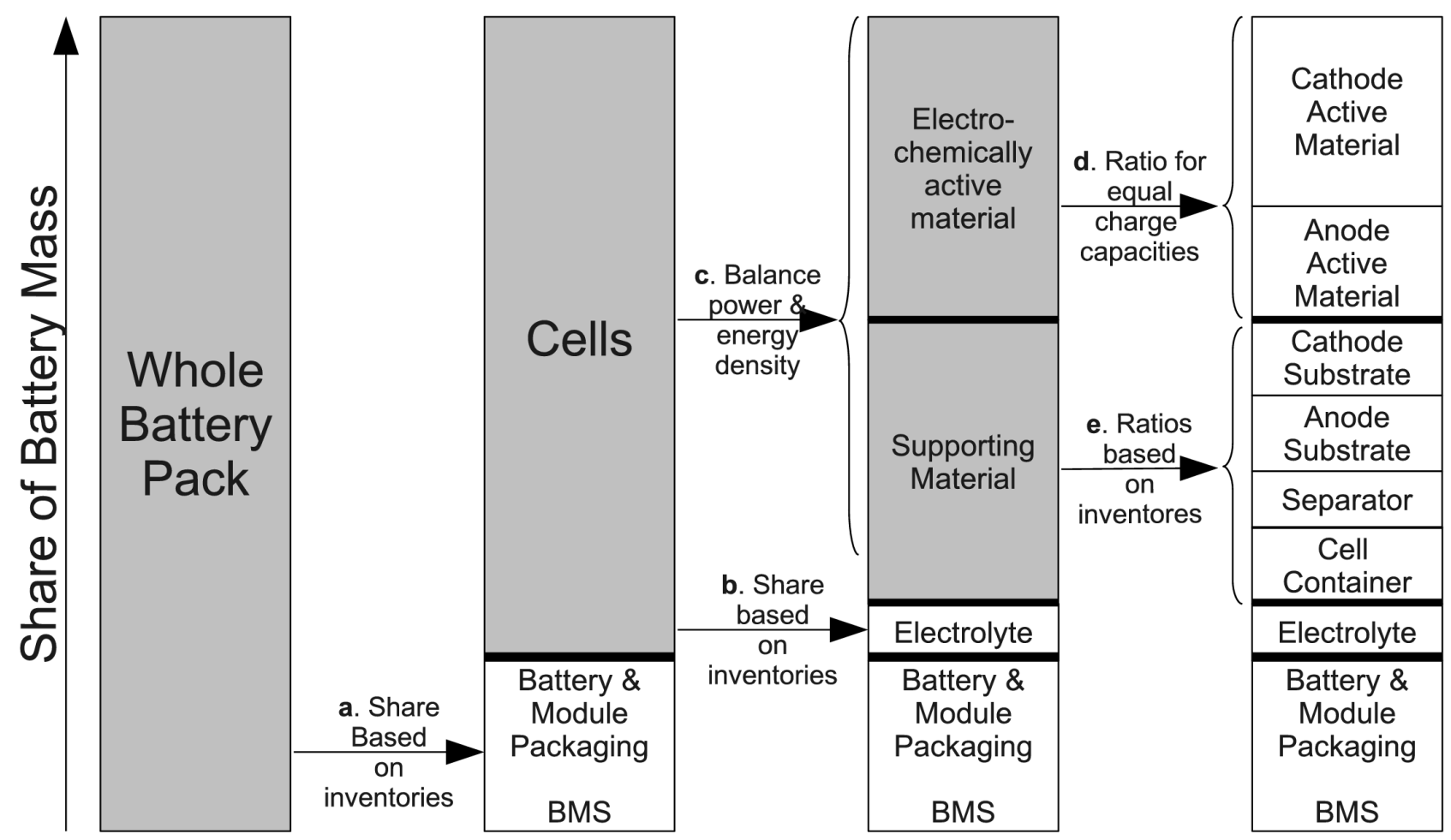

Figure S2. Procedure used to model batteries of the desired power and energy densities with different chemistries. First the mass of the non-cell components and of the electrolyte form was fixed $(a, b)$. The share of the cell represented by of electrochemically active materials was chosen depending on the desired total energy density and the properties of the materials (c). The mass ratios of positive and negative electrodes was chosen so that they would have equal reversible charge capacities (d). The remainder of the cell mass was divided amongst the supporting materials (e).

Of all the components, the mass share of the electrolyte was found to be the most insensitive to differences in battery design, ranging from $18 \%$ of cell mass for high energy Li-ion batteries to $13.5 \%$ for high power ones (4). For the two Li-ion batteries, we allocated to electrolyte $15 \%$ of the cell mass, 
i.e. roughly $12 \%$ of battery mass (Figure S2, step b). For NiMH, the aqueous electrolyte represents $9 \%$ of the mass, following the inventory by Schexnayder et al. (7).

The remainder of the cell masses were "designed" so as to obtain realistic high-energy performances for all three investigated chemistries. The amounts of electrode pastes were chosen so that the product of their charge capacities and their nominal voltage would yield a credible energy density for the battery (Figure S2, step c). Furthermore, the mass proportions between positive and negative electrode pastes were chosen so that both electrodes would have an identical reversible charge capacity (Figure S2, step d). In the inventories by Gaines and Cuenca (4), the mass ratios between the remaining "supporting" components was fixed, regardless of the energy/power density design. The remainder of the Li-ion battery was thus divided between cathode current collector, anode current collector, separator material and container components according to these ratios (Figure S2, step e). The same approach was used to quantify the supporting components for the NiMH batteries, with the ratios based on the inventories by Schexnayder et al. (7) and Ying et al. (8).

Figure S2 presents conceptually how our inventories were constructed so as to be representative of PHEV and BEV technologies. Practically, the state of the art electrochemical properties of the different electrode materials were reported in Table S1-I. Based on these, the inventories of Singh et al. (9), Gaines and Cuenca (4), Schexnayder et al. (7), and Ying et al. (8) were combined and retrofitted (Table S1-II) so that they should yield credible PHEV and BEV battery performances representative of industry expectations (Table S1-III). The total lifetime specific energy capacities of the batteries were reported in (Table S1-IV), and their calcutions detailed in Section 3. 
Table S1: Electrochemical characteristics, component mass breakdown and performance of three modeled traction batteries

\section{NiMH}

Li-ion

\begin{tabular}{|c|c|c|c|}
\hline & & & \\
\hline & $\mathbf{A B}_{5}$ & NCM & LFP \\
\hline I. Electrochemical Properties & & & \\
\hline Cell voltage $(\mathrm{V})$ & $1.2^{\mathrm{a}, \mathrm{b}}$ & $3.7^{\mathrm{c}, \mathrm{d}, \mathrm{e}}$ & $3.4^{\mathrm{e}, \mathrm{f}, \mathrm{g}}$ \\
\hline Capacity of pure active material, positive electrode $\left(1 \mathrm{C}\right.$ rate $\left.{ }^{\dagger}\right)\left(\mathrm{mAh} \cdot \mathrm{g}^{-1}\right)$ & $275^{\mathrm{h}}$ & $150^{\mathrm{c}, \mathrm{i}}$ & $120^{\mathrm{j}, \mathrm{k}}$ \\
\hline Capacity of pure active material, negative electrode $\left(1 \mathrm{C}\right.$ rate $\left.{ }^{\dagger}\right)\left(\mathrm{mAh} \cdot \mathrm{g}^{-1}\right)$ & $290^{\mathrm{h}}$ & $350^{1}$ & $350^{1}$ \\
\hline Cycle depth of discharge (DoD) $(\%)$ & $80^{\mathrm{d}}$ & $80^{\mathrm{c}, \mathrm{d}, \mathrm{e}}$ & $80^{\mathrm{d}, \mathrm{g}}$ \\
\hline Charge-discharge energy efficiency $(\%)$ & $80^{\mathrm{m}, \mathrm{v}}$ & $90^{\mathrm{n}, \mathrm{op}, \mathrm{p}, \mathrm{v}, \mathrm{v}}$ & $90^{\mathrm{n}, \mathrm{op}, \mathrm{q}, \mathrm{v}, \mathrm{v}}$ \\
\hline Cycle life expectancy (ca. 80\% DoD) (cycles) & $3000^{\mathrm{d}, \mathrm{ef}}$ & $3000^{\mathrm{e}, \mathrm{f}, \mathrm{r}}$ & $6000^{\mathrm{e}, \mathrm{f}, \mathrm{s}}$ \\
\hline II. Battery mass composition (\%) & & & \\
\hline Positive electrode paste & $19.7^{\mathrm{t}}$ & $23.2^{, \mathrm{u}}$ & $24.8^{\mathrm{u}}$ \\
\hline Negative electrode paste & $12.6^{\mathrm{t}}$ & $9.4^{u}$ & $8.0^{\mathrm{u}}$ \\
\hline Separator & $3.8^{\mathrm{h}, \mathrm{t}, \mathrm{v}}$ & $3.3^{\mathrm{u}}$ & $3.3^{\mathrm{u}}$ \\
\hline Substrate, positive electrode & $17.3^{\mathrm{h}, \mathrm{t}}$ & $3.6^{\mathrm{u}}$ & $3.6^{\mathrm{u}}$ \\
\hline Substrate, negative electrode & $11.1^{\mathrm{t}}$ & $8.3^{\mathrm{u}}$ & $8.3^{\mathrm{u}}$ \\
\hline Electrolyte & $9.0^{\mathrm{t}}$ & $12.0^{\mathrm{u}}$ & $12.0^{\mathrm{u}}$ \\
\hline Cell container, tab and terminals & $9.5^{\mathrm{h}, \mathrm{t}}$ & $20.1^{\mathrm{u}}$ & $20.0^{\mathrm{u}}$ \\
\hline Module and battery packaging & $17.0^{\mathrm{h}, \mathrm{t}}$ & $17.0^{\mathrm{u}}$ & $17.0^{\mathrm{u}}$ \\
\hline Battery management system (BMS) & - & $3.0^{\mathrm{t}}$ & $3.0^{\mathrm{t}}$ \\
\hline III. Battery Performance (Calculated from I and II) & & & \\
\hline Nominal Cell capacity $\left(1 \mathrm{C}\right.$ rate $\left.^{\dagger}\right)\left(\mathrm{Ah} \cdot \mathrm{kg}_{\text {cell }}^{-1}\right)$ & 55.5 & $37.9^{r}$ & 32.3 \\
\hline Nominal Cell energy density $\left(1 \mathrm{C}\right.$ rate $\left.^{\dagger}\right)\left(\mathrm{Wh} \cdot \mathrm{kg}_{\text {cell }}{ }^{-1}\right)$ & 66.6 & $140^{\mathrm{r}, \mathrm{d}}$ & $110^{\mathrm{w}}$ \\
\hline Total battery pack energy density $\left(\mathrm{Wh} \cdot \mathrm{kg}^{-1}\right)$ & $55.3^{\mathrm{d}, \mathrm{e}}$ & $112^{\mathrm{e}}$ & 88.0 \\
\hline Total battery pack power density $\left(\mathrm{W} \cdot \mathrm{kg}^{-1}\right)$ & $200-400^{\mathrm{d}, \mathrm{e}}$ & $400-800^{\mathrm{e}, \mathrm{r}}$ & $400-800^{\mathrm{e}}$ \\
\hline IV. Lifetime output (Calculated from I, II, III) & & & \\
\hline Lifetime specific energy capacity $(80 \% \mathrm{DoD})\left(\mathrm{MJ} \cdot \mathrm{kg}^{-1}\right)$ & 478 & 969 & 1520 \\
\hline $\begin{array}{l}\text { Based on, or in approximate agreement with: }{ }^{\mathrm{a}} \text { Hamann et al. }(10),{ }^{\mathrm{b}} \text { Linden a } \\
\text { et al. (5), }{ }^{\mathrm{e}} \text { Kalhammer et al. }(2),{ }^{\mathrm{f}} \text { Shukla and Kumar }(13),{ }^{\mathrm{g}} \text { Chen and Whitti } \\
\text { j } \text { Arnold et al. }(16),{ }^{\mathrm{k}} \text { Le Cras et al. }(17),{ }^{\mathrm{l}} \text { Yoshio et al. }(18),{ }^{\mathrm{m}} \text { Ikeya et al. }(19 \\
\text { Den Bossche et al. }(22),{ }^{\mathrm{q}} \text { Tanaka et al. }(23),{ }^{\mathrm{r}} \text { Kokam Co. Ltd. }(24),{ }^{\mathrm{s}} \text { Takaha } \\
\text { u } \text { Gaines and Cuenca (4), }{ }^{\mathrm{v}} \text { Rydh and Sandén }(26),{ }^{\mathrm{w}} \text { Deveney et al. (27) }\end{array}$ & $\begin{array}{l}\text { Magnusen }(1 \\
\text { Im }(14),{ }^{\mathrm{h}} \mathrm{Y} \\
\text { Karden et al. } \\
\text { et al. }(25),{ }^{\mathrm{t}}\end{array}$ & $\begin{array}{l},{ }^{\mathrm{c}} \text { Ngala et } \\
\text { et al. (8), }{ }^{\mathrm{i}} \\
\text { 0), }{ }^{\circ} \text { Shiau } \\
\text { hexnayder }\end{array}$ & $\begin{array}{l}\text { 12), }{ }^{\mathrm{d}} \text { Axser } \\
\text { (15), } \\
\text { (21), }{ }^{\mathrm{p}} \text { Var } \\
\text { (7), }\end{array}$ \\
\hline
\end{tabular}

\section{Inventory of battery use-phase}

The use-phase consists of charging and discharging the battery. Due to internal resistance, energy is lost as heat during the process. The electrical energy wasted is accounted as a requirement, and the heat is accounted as the only direct emission. Also, as the battery has a limited lifetime, a fraction of the battery assembly and final shipping is allocated to each charge-discharge functional unit.

$\dagger \mathrm{A}$ rate of $\mathrm{nC}$ is defined as the current that is equivalent to the full capacity of the battery being charged or discharged in $1 / \mathrm{n}$ hours. 
The total lifetime energy capacity $\left(\mathrm{C}^{\mathrm{tl}}\right)$ was equated to the energy capacity of a full charge-discharge cycle $\left(\mathrm{C}_{\mathrm{u}}\right)$, multiplied by an $80 \%$ depth-of-discharge (DoD) and the expected cycle-life of the battery under $80 \%$ depth-of-discharge and normal use $\left(\mathrm{L}_{80 \%}\right)$. The energy capacity was in turn approximated from the nominal voltage $(V)$ and the charge capacity $\left(C_{C}\right)$ of the modeled cells [eq. 1].

$$
\mathrm{C}_{\mathrm{U}}^{\mathrm{t}}=\mathrm{C}_{\mathrm{U}} \mathrm{DoD}_{80 \%} \mathrm{~L}_{80 \%} \approx \mathrm{V} \mathrm{C}_{\mathrm{C}} \mathrm{DoD}_{80 \%} \mathrm{~L}_{80 \%}
$$

This approach constitutes a "deep cycle approach", representative of the battery use for PHEV and BEV, contrarily to shallow cycles with ca. 20\% DoD for stop-and-go HEV (28). Charge capacity, DoD, and cycle-life expectancies are presented for each battery in Table S1. Since the Japanese industry is an important actor in the traction battery market (4), the transoceanic freight shipping to Europe covers the distance Honshu, Japan (29).

Table S2: Inventory of requirements and emissions for $1 \mathrm{MJ}$ of battery use

\begin{tabular}{lccc}
\hline Parameter & NiMH AB & Li-ion NCM & Li-ion LFP \\
\hline $\begin{array}{l}\text { Functional unit output } \\
\quad \text { Energy stored and delivered to power-train(MJ) }\end{array}$ & 1 & 1 & 1 \\
Materials and energy & & & \\
$\quad$ Electricity, average UCTE (kWh) & 0.20 & 0.10 & 0.10 \\
$\quad$ Battery Manufacture (kg) & $2.1 \times 10^{-2}$ & $1.0 \times 10^{-3}$ & $6.6 \times 10^{-4}$ \\
$\quad \begin{array}{l}\text { Transport } \\
\quad \text { Transoceanic freight ship (OCE) (tkm) }\end{array}$ & $4.6 \times 10^{-5}$ & $2.3 \times 10^{-5}$ & $1.5 \times 10^{-5}$ \\
$\quad$ Emissions \\
$\quad$ Waste heat to air (MJ)
\end{tabular}

\section{Inventory of Li-Ion batteries production}

\subsection{Manufacture of Li-Ion battery and subcomponents}

The positive and negative electrode pastes are typically mixed on-site at the battery assembly. A coating machine then applies a thin layer (200-250 $\mu \mathrm{m}$ for high energy cells) on both sides of the electrode substrates (metal foils) (4). The applied slurry is dried and pressed (30). The positive electrode, the separator, and the negative electrode are then sandwiched together and wound-up inside the cell container. The cells are filled with electrolyte and closed. Cells are always assembled fully discharged (all lithium ions in cathode). The cells then undergo a certain number of charge-discharge cycles and compliance tests. Finally, the cells are combined in modules and battery packs, with the necessary control circuits (4).

The material requirements were determined based on the modeled component mass ratios of Table S1. The energy requirements were discussed below in Sections 8.2 and 8.3. Water, transport, and infrastructure requirements were taken from the LCA of laptop batteries by Hischier et al. (31). 
Table S3: Li-ion battery and subcomponent production

\begin{tabular}{|c|c|c|c|}
\hline \multirow[t]{2}{*}{ Parameter } & \multicolumn{2}{|c|}{ Amount } & \multirow[t]{2}{*}{ Sub-Inventory } \\
\hline & NCM & LFP & \\
\hline \multicolumn{4}{|l|}{ Functional Unit Output } \\
\hline \multicolumn{4}{|l|}{ Li-Ion battery, assembled (kg) } \\
\hline \multicolumn{4}{|l|}{ Material Requirements } \\
\hline Positive electrode paste for Li-ion battery (kg) & $2.3 \times 10^{-1}$ & $2.5 \times 10^{-1}$ & Section 4.2 \\
\hline Negative electrode paste for Li-ion battery $(\mathrm{kg})$ & $9.4 \times 10^{-2}$ & $8.0 \times 10^{-2}$ & Section 4.3 \\
\hline Positive electrode substrate for Li-ion battery $(\mathrm{kg})$ & $3.6 \times 10^{-2}$ & $3.6 \times 10^{-2}$ & Section 4.7 \\
\hline Negative electrode substrate for Li-ion battery (kg) & $8.3 \times 10^{-2}$ & $8.3 \times 10^{-2}$ & Section 4.7 \\
\hline Electrolyte for Li-ion battery $(\mathrm{kg})$ & $1.2 \times 10^{-1}$ & $1.2 \times 10^{-1}$ & Section 4.4 \\
\hline Separator $(\mathrm{kg})$ & $3.3 \times 10^{-2}$ & $3.3 \times 10^{-2}$ & Section 6.2 \\
\hline Cell container, tab and terminals $(\mathrm{kg})$ & $2.0 \times 10^{-1}$ & $2.0 \times 10^{-1}$ & Section 6.1 \\
\hline Module and Battery Packaging (kg) & $1.7 \times 10^{-1}$ & $1.7 \times 10^{-1}$ & Section 6.3 \\
\hline Battery management system (BMS) (kg) & $3.0 \times 10^{-2}$ & $2.0 \times 10^{-2}$ & Section 4.8 \\
\hline Water, decarbonated & 380 & 380 & \\
\hline \multicolumn{4}{|l|}{ Processing and Energy requirements } \\
\hline Electricity, medium voltage, UCTE, at grid (MJ) & 27 & 27 & \\
\hline Heat, light fuel oil, at industrial furnace 1MW & 2.9 & 2.9 & \\
\hline Heat, natural gas, industrial furnace low-NOx > $100 \mathrm{~kW}$ & 22 & 22 & \\
\hline \multicolumn{4}{|l|}{ Transport Requirements } \\
\hline Freight rail transport (tkm) & $2.3 \times 10^{-1}$ & $2.3 \times 10^{-1}$ & \\
\hline Lorry $>16 \mathrm{t}(\mathrm{tkm})$ & $5.1 \times 10^{-2}$ & $5.1 \times 10^{-2}$ & \\
\hline \multicolumn{4}{|l|}{ Infrastructure } \\
\hline Facility, precious metal refinery (SE) (unit) & $1.9 \times 10^{-8}$ & $1.9 \times 10^{-8}$ & \\
\hline \multicolumn{4}{|l|}{ Emissions } \\
\hline Waste heat (MJ) & 52 & 52 & \\
\hline
\end{tabular}

\subsection{Production of positive electrode pastes for lithium ion battery (NCM or LFP)}

The electrode pastes of lithium ion positive electrodes are composed of the electrochemically active material, a binder substance (ca. 5-10\%) and carbon black to improve conductivity (ca. 4-10\%). The inventoried active materials are lithium iron phosphate $\left(\mathrm{LiFePO}_{4}\right)$ and lithium nickel-cobalt-manganese oxide $\left(\mathrm{LiNi}_{0.4} \mathrm{Co}_{0.2} \mathrm{Mn}_{0.4} \mathrm{O}_{2}\right)$, respectively for LFP and NCM. It is an important insight that the metal constituents of both these compounds are in their oxidized state. Throughout their production chain these elements never undergo the highly energy-intensive process of reduction to the metallic form. The use of metal salts instead of pure metals distinguishes our inventory from those of Hischier et al. (31), Schexnayder et al. (7), and Burnham et al. (32).

The most commonly mentionned binders are poly(vinylidene fluoride) (PVDF) and polytetrafluoroethylene (PTFE), but poly(acrylonitrile-methyl methacrylate) (AMMA) is also the object of research $(4,33-36)$. For carbon black, little gain is observed in increasing concentrations beyond $6 \%(35,36)$. N-methylpyrrolidinone (NMP) is the preferred solvent to give the mixture a slurry texture $(4,30,33)$. The solvent is evaporated after application of the electrode material on the substrate. 
In this inventory, the same mass compositions were assumed for LFP and NCM electrodes. The active material accounted for $88 \%$ of the mass, a PTFE binder for $8 \%$ and carbon black for $5 \%$. The amount of NMP solvent was estimated at $28 \mathrm{~g}$ per kilo of dry electrode material, based on the Ecoinvent inventory of $\mathrm{LiMn}_{2} \mathrm{O}_{4}$ electrode (31). No infrastructure use was allocated to this process, as it would typically be performed on-site at the battery assembly plant (4). The simple mixing step is not expected to lead to any significant energy consumption, emissions, or material loss. For mass balance and simplicity, the complete evaporation of the NMP solvent (after application of the paste on the substrate) was allocated to this process instead of final assembly. The detailed inventory may be found in Table S4.

Table S4: Inventory for the production of $1 \mathrm{~kg}$ of positive electrode material for Li-Ion battery, either LFP or NCM.

\begin{tabular}{|c|c|c|}
\hline Process & Amount & Sub-Inventory \\
\hline \multicolumn{3}{|l|}{ Functional Unit Output } \\
\hline Positive electrode material for Li-Ion (LFP or NCM) at plant (kg, dry) & 1 & \\
\hline \multicolumn{3}{|l|}{ Material Requirements } \\
\hline $\begin{array}{l}\text { For LFP: Lithium iron phospahte }[\mathrm{LiFePO}](\mathrm{kg}) \\
\text { For NCM: Lithium nickel cobalt manganese hydroxide }\left[\mathrm{LiNi}_{0.4} \mathrm{Co}_{0.2} \mathrm{Mn}_{0.4} \mathrm{O}_{2}\right](\mathrm{kg})\end{array}$ & 0.87 & $\begin{array}{l}\text { Section } 4.5 \\
\text { Section } 4.6\end{array}$ \\
\hline Carbon black, GLO $(\mathrm{kg})$ & 0.05 & \\
\hline Polytetrafluoroethylene (PTFE) (kg) & 0.08 & \\
\hline N-methyl-2-pyrrolidone (NMP) (kg) & 0.28 & \\
\hline \multicolumn{3}{|l|}{ Transport Requirements } \\
\hline Freight rail transport (tkm) & 3.8 & \\
\hline Lorry $>16 \mathrm{t}(\mathrm{tkm})$ & 0.7 & \\
\hline \multicolumn{3}{|l|}{ Emissions } \\
\hline N-methyl-2-pyrrolidone (NMP), to air, unspecified (kg) & 0.28 & \\
\hline
\end{tabular}

Most lithium ion batteries presently rely on graphite electrodes. Research into electrodes based on silicon or germanium nanomaterials, amorphous carbon, carbon nanotubes, and metal alloys is ongoing $(13,37-40)$. To ensure the absence of any oxygen impurity in the graphite, it is baked at $1100^{\circ} \mathrm{C}$ in an inert or reducing atmosphere (4). The negative electrode paste is typically composed of graphite and a PTFE or PVDF binder (ca. 5\%). NMC solvent is added to the mixture, to be evaporated after the paste has been applied to the substrate $(4,30,33)$.

In this inventory, the binder is assumed to be PTFE. The amount of NMP required was set equal to the requirements of the positive electrode. The energy requirement to bake the graphite was estimated from the carbon anode baking of the aluminum industry, which requires $4.8-5.2 \mathrm{MJ} \cdot \mathrm{kg}^{-1}$. The NMP solvent evaporation to air was assigned to this process (instead to battery assembly, see section4.1) for mass balance and simplicity. This process is assumed to be carried out on-site at the battery assembly plant, and consequently no facility requirement was assigned to this process (4). The inert or reducing atmosphere needed during baking was not included in this inventory due to lack of data. The inventory may be found in Table S5. 
Table S5: Inventory for the production of $1 \mathrm{~kg}$ (dry) of negative carbonaceous electrode material for Li-Ion battery.

\begin{tabular}{lc}
\hline Process & Amount \\
\hline Functional Unit Output & 1 \\
$\quad$ Negative electrode material for Li-ion battery (kg, dry) & \\
Material Requirements & 0.95 \\
$\quad$ Graphite (kg) & 0.05 \\
Polytetrafluoroethylene (PTFE) (kg) & 0.28 \\
N-methyl-2-pyrrolidone (NMP) (kg) & 5.0 \\
Energy and Processing & \\
Heat, unspecified, in chemical plant (graphite baking) (MJ) & 0.2 \\
Transport Requirements & 0.1 \\
Freight rail transport (tkm) & \\
Lorry >16t (tkm) & 5.0 \\
Emissions & 0.28 \\
Heat waste (MJ) & \\
N-methyl-2-pyrrolidone (NMP), to air, unspecified (kg) & \\
\hline
\end{tabular}

\subsection{Production of electrolyte for Li-ion battery}

The liquid electrolytes are generally composed of ca. 1 molar solutions of lithium salts in a mixture of alkylcarbonate solvents $(4,41)$. The solvent always includes ethylene carbonate (EC) for anode passivation (42), generally complemented with dimethyl- or diethyl- carbonates (DMC, DEC) (37). Ethylmethylcarbonate (EMC), propylene carbonate (PC), and dimethoxyethane (DME) are also mentioned $(4,42)$. Lithium hexafluorophosphate $\left(\mathrm{LiPF}_{6}\right)$ is now the salt of choice in the industry, in spite of its tendency to generate hydrofluoric acid (HF) upon degradation $(37,41)$.

The production of $\mathrm{LiPF}_{6}$ or alkyl carbonate solvents were not modeled. Rather, generic "chemicals organic" and "chemicals inorganic" proxies were used. The simple steps of mixing the solvents and dissolving the salt were not expected to require significant energy inputs, nor lead to significant material losses or direct emissions. The infrastructure use was based on the "chemical plant, organics" from Ecoinvent . The detailed inventory may be found in Table S6.

Table S6: Inventory for the production of $1 \mathrm{~kg}$ of electrolyte for Li-ion battery, $1 \mathrm{M} \mathrm{LiPF}_{6}$.

\begin{tabular}{lc}
\hline Process & Amount \\
\hline Functional Unit Output & \\
$\quad$ Electrolyte for Li-ion Battery, $1 \mathrm{M} \mathrm{LiPF}_{6}(\mathrm{~kg})$ & 1 \\
Material Requirements & 0.12 \\
$\quad$ Chemicals, inorganic [proxy for $\left.\mathrm{LiPF}_{6}\right]$ & 0.88 \\
$\quad$ Chemicals, organic [proxy for solvent] & \\
Transport Requirements & 0.6 \\
Freight rail transport (tkm) & 0.1 \\
Lorry >16t (tkm) & \\
Infrastructure Requirements & $4.0 \times 10^{-10}$ \\
$\quad$ Chemical plant, organics (unit) & \\
\hline
\end{tabular}




\subsection{Production of $\mathrm{LiFePO}_{4}$}

Many synthesis routes exist to produce lithium iron phosphate $\left(\mathrm{LiFePO}_{4}\right)$ : solid state reaction at high temperature, co-precipitationn in aqueous medium, hydrothermal synthesis, or mechanochemical activation (17). The hydrothermal path was inventoried based on the synthesis protocol of (14). An iron sulphate salt $\left(\mathrm{FeSO}_{4} \cdot 7 \mathrm{H}_{2} \mathrm{O}\right)$ was reacted with phosphoric acid $\left(\mathrm{H}_{3} \mathrm{PO}_{4}\right)$ and lithium hydroxide $(\mathrm{LiOH})$ in water in a sealed reactor at ca. $150-200^{\circ} \mathrm{C}$ for 5 hours (equation 2). Stoichiometric molar ratios were used, with an iron sulphate concentration of $22 \mathrm{~g} \cdot \mathrm{L}^{-1}$. The $\mathrm{LiFePO}_{4}$ precipitate was collected by suction filtration and dried at $60^{\circ} \mathrm{C}$ for $5 \mathrm{~h}$. With a similar protocol, (43) reported yields between $95-$ $98 \%$, depending on $\mathrm{pH}$.

$$
3 \mathrm{LiOH}_{(\text {aq) }}+\mathrm{H}_{3} \mathrm{PO}_{4(\mathrm{aq})}+\mathrm{FeSO}_{4(\mathrm{aq})} \rightarrow \mathrm{LiFePO}_{4(\mathrm{~s})}+\mathrm{Li}_{2} \mathrm{SO}_{4(\mathrm{aq})}+3 \mathrm{H}_{2} \mathrm{O}_{(\mathrm{l})}
$$

For this inventory, a 95\% yield was assumed. Lost product and co-products were assumed to be released in the hydrosphere. Total heat requirements $\left(q_{t o t}\right)$ were modeled assuming ideal thermodynamic heating of the solvent $\left(q_{s}\right)$, heat losses by the reactor during reaction $\left(q_{r}\right)$, and recuperation of roughly half of the heat content of the solvents after the reaction (eq. 3).

$$
q_{\text {tot }}=q_{s}+q_{r}-\frac{q_{s}}{2}
$$

Heat losses during reaction were modeled as in equation 4, with constant heat flux $(\Phi)$ for a given reaction time $\left(t_{r}\right)$. For the reactor, we assumed a $10 \mathrm{~m}^{3}$ cylindrical tank, with an surface area $(A)$ of ca. $25 \mathrm{~m}^{2}$, covered by an insulated mineral wool layer with a thickness $(x)$ of $0.1 \mathrm{~m}$ and a thermal conductivity $(\lambda)$ of $0.040 \mathrm{~W} \cdot \mathrm{m}^{-1} \cdot \mathrm{K}^{-1}$. We further assumed a constant external wall temperature $\left(T_{o}\right)$ of $50^{\circ} \mathrm{C}$ and a reaction temperature $\left(T_{i}\right)$ of $200^{\circ} \mathrm{C}$.

$$
q_{r}=\Phi t_{r}=\lambda A \frac{\left(T_{r}-T_{o}\right)}{x} t_{r}
$$

The energy required for the initial heating of the solvent proved to be 2 orders of magnitude greater than the modeled reactor heat loss. The energy required to dry the product was ignored, as was the enthalpy of reaction. The inventory may be found in Table S7. It should be noted that, as by-products of the iron industry, iron sulphate is only assigned energy requirements by the Ecoinvent database. Evidently, material requirements are thus being ignored. 
Table S7: Inventory for the production of $1 \mathrm{~kg}$ of lithium iron phosphate.

\begin{tabular}{lc}
\hline Process & Amount \\
\hline Functional Unit Output & 1 \\
$\quad$ Lithium iron phosphate $\left(\mathrm{LiFePO}_{4}\right)$ & 0.46 \\
Material Requirements & 0.65 \\
$\quad$ Lithium hydroxide $(\mathrm{LiOH})(\mathrm{kg})$ & 1.0 \\
Phosphoric acid $\left(\mathrm{H}_{3} \mathrm{PO}_{4}\right)(\mathrm{kg})$ & 46 \\
Iron Sulphate $(\mathrm{FeSO})(\mathrm{kg})$ & \\
Deionised water $(\mathrm{kg})$ & 15 \\
Energy and Processing Requirements & \\
$\quad$ Heat, unspecified, in chemical plant $(\mathrm{MJ})$ & 1.3 \\
Transport Requirements & 0.21 \\
$\quad$ Freight rail transport (tkm) & \\
Lorry $>16 \mathrm{t}(\mathrm{tkm})$ & $4.0 \times 10^{-10}$ \\
Infrastructure Requirements & \\
Chemical plant, organics (unit) & 0.10 \\
Emissions & $1.9 \times 10^{-2}$ \\
Lithium ion, to water, unspecified & $3.2 \times 10^{-2}$ \\
Iron ion, to water, unspecified & 1.5 \\
Phosphate ions, to water, unspecified & \\
Waste heat (MJ) &
\end{tabular}

\subsection{Production of $\mathrm{LiNi}_{0.4} \mathrm{Co}_{0.2} \mathrm{Mn}_{0.4} \mathrm{O}_{2}$}

The inventory of lithium nickel cobalt manganese oxide $\left(\mathrm{LiNi}_{0.4} \mathrm{Co}_{0.2} \mathrm{Mn}_{0.4} \mathrm{O}_{2}\right)$ production from lithium hydroxide $(\mathrm{LiOH})$ and nickel cobalt manganese hydroxide $\left(\mathrm{Ni}_{0.4} \mathrm{Co}_{0.2} \mathrm{Mn}_{0.4}(\mathrm{OH})_{2}\right)$ was based on protocol descriptions by Liu (15) and Ngala et al. (12). The two hydroxide salts were jointly ground and pelleted, and then precalcinated at $450^{\circ} \mathrm{C}$ for $12 \mathrm{~h}$. The material was then reground, repelletized, and then heated for $8 \mathrm{~h}$ at ca. $800^{\circ} \mathrm{C}$. Overall reaction presented in equation 5 .

$$
\mathrm{Ni}_{0.4} \mathrm{Co}_{0.2} \mathrm{Mn}_{0.4}(\mathrm{OH})_{2}+\mathrm{LiOH} \cdot \mathrm{H}_{2} \mathrm{O}+0.25 \mathrm{O}_{2} \rightarrow \mathrm{LiNi}_{0.4} \mathrm{Co}_{0.2} \mathrm{Mn}_{0.4} \mathrm{O}_{2}+2.5 \mathrm{H}_{2} \mathrm{O}
$$

No significant material loss was expected from this step. No data was available concerning emissions. To estimate energy requirements, we modeled the calcination in a chamber furnace. We strarted with a 8300 litre Nabertherm W83000/85A chamber furnace, with maximum temperature of $850^{\circ} \mathrm{C}$ and a $200 \mathrm{~kW}$ connected load $(44)$. At $800^{\circ} \mathrm{C}$, we estimated that a $100 \mathrm{~kW}$ half-load is necessary to maintain furnace at $800^{\circ} \mathrm{C}$, and $12.5 \mathrm{~kW}$ for $405^{\circ} \mathrm{C}$. We further assumed a coefficient of utilization of $33 \%$. With these parameters, ca. $1 \mathrm{MJ}$ is required per litre processed. From the molar ratios and densities of the chemicals in equation 5, we estimate a volume of inputs of 0.551 per $\mathrm{kg}$ of final product, and thus an energy requirement of $0.55 \mathrm{MJ} \cdot \mathrm{kg}^{-1}$. Energy requirements for grinding and pelleting were ignored. The process inventory was compiled in Table S8. 
Table S8: Inventories for the production of $1 \mathrm{~kg}$ of $\mathrm{LiNi}_{0.4} \mathrm{Co}_{0.2} \mathrm{Mn}_{0.4} \mathrm{O}_{2}$.

\begin{tabular}{lcc}
\hline Process & Amount & Sub-Inventory \\
\hline Functional Unit Output & \\
$\quad$ Lithium nickel cobalt manganese oxide $\left(\mathrm{LiNi}_{0.4} \mathrm{Co}_{0.2} \mathrm{Mn}_{0.4} \mathrm{O}_{2}\right)(\mathrm{kg})$ & 1 \\
Material Requirements & 0.25 \\
$\quad$ Lithium hydroxide $(\mathrm{LiOH})(\mathrm{kg})$ & 0.95 & Section 7.1 \\
$\quad$ Nickel cobalt manganese hydroxide $\left(\mathrm{Ni}_{0.4} \mathrm{Co}_{0.2} \mathrm{Mn}_{0.4}(\mathrm{OH})_{2}\right)(\mathrm{kg})$ & \\
Energy and Processing Requirements & 0.55 \\
$\quad$ Heat, unspecified, in chemical plant $(\mathrm{MJ})$ & \\
Transport Requirements & 0.72 \\
$\quad$ Freight rail transport (tkm) & 0.12 \\
$\quad$ Lorry $>16 t$ (tkm) & \\
Infrastructure Requirements & $4.6 \times 10^{-10}$ \\
$\quad$ Chemical plant, organics (unit) & \\
Emissions & 5.5 \\
$\quad$ Waste heat (MJ) & 5 \\
\hline
\end{tabular}

\subsection{Production of electrode substrates for lithium ion battery}

The electrode paste rests on a thin (ca. 15-20 $\mu \mathrm{m}$ ) metal foil, which serves as a physical support and as a current collector. Aluminum foil is used for the positive electrode, while for the negative electrode copper is preferred $(4,30)$.

No data was available concerning the actual foil fabrication process. For this inventory, "sheet rolling" process was used as a proxy. The inventory may be found in Table S9.

Table S9: Inventories for the production of $1 \mathrm{~kg}$ of electrode substrate for Li-ion battery (positive or negative)

Process

Functional Unit Output

Li-ion electrode substrate (positive or negative), at plant (kg)

Material Requirements

Positive electrode: Aluminium, production mix (kg)

Negative electrode: Copper, primary, GLO (kg)

Energy and Processing Requirements

Positive electrode: Sheet rolling, aluminum $(\mathrm{kg})$

Negative electrode: Sheet rolling, copper $(\mathrm{kg})$

Transport Requirements

Freight rail transport (tkm)

Lorry $>16 \mathrm{t}(\mathrm{tkm})$

Infrastructure Requirements

Metal working factory (unit)

GLO = Global average

\section{Amount}




\subsection{Production of battery management system}

Li-ion cells require control circuitry to prevent situations of over-charging or over-discharging. Contrarily to NiMH cells and other aqueous electrolyte based chemistries, Li-ion cells are devoid of any inherent stabilization mechanism, and thus require active external control (4). These include voltage or temperature cut-off control circuits, bypass circuits, fuses, positive coefficient devices (13, 30).

The mass breakdown by Schexnayder et al. (7), estimated that the battery management system (BMS) represented ca. $4 \%$ of the battery mass. Circuit boards and wires each constituted about half of this mass. We feel that this may overestimate the relative importance of the BMS. Rather, our best estimate assumes the BMS to represent ca. 3\% relative to the whole battery pack, with integrated circuits accounting for roughly $10 \%$ of of the BMS mass. Copper wires (both for internal and external cabling) were assumed to represent half of the BMS mass, and a stainless steel container the remainder (Table S10).

Table S10: Production of $1 \mathrm{~kg}$ of battery management system for Li-ion battery

\begin{tabular}{lc}
\hline Process & Amount \\
\hline Functional Unit Output & 1 \\
$\quad$ Battery management system for Li-ion battery $(\mathrm{kg})$ & \\
Material Requirements & 0.1 \\
$\quad$ Integrated circuit, logic type, at plant $(\mathrm{kg})$ & 0.5 \\
Copper, primary, at refinery $(\mathrm{kg})$ & 0.4 \\
Chromium steel $18 / 8(\mathrm{~kg})$ & \\
Energy and Processing Requirements & 0.5 \\
$\quad$ Wire drawing, cooper $(\mathrm{kg})$ & 0.4 \\
Sheet rolling, steel (kg) & \\
Transport Requirements & 0.2 \\
$\quad$ Freight rail transport (tkm) & 0.1 \\
$\quad$ Lorry $>16 \mathrm{t}$ (tkm) & \\
Infrastructure Requirements & $2.3 \times 10^{-10}$ \\
$\quad$ Plastic processing factory (unit) & \\
\hline
\end{tabular}

\section{Inventory of NiMH battery production}

\subsection{Manufacture of NiMH Battery and subcomponents}

The assembly of NiMH batteries resembles that of Li-ion batteries. For both the negative and the positive electrodes, the electrode paste is applied in the porous substrate. The slurry is dried and roll pressed (8). The electrodes are then wound together with the separator, inserted in the cell container and put in contact with the electrolyte (11). After testing, the cells are combined in modules and battery packs.

The inventoried material requirements are based on the mass shares of the components of the modeled NiMH (see Table S1). Energy requirements were taken from Rydh and Sandén (26), as 
discussed in Sections 8.2 and 8.3, below. Direct water, transport, and infrastructure inputs were taken Hischier et al. (31). The process inventory was compiled in Table S11.

Table S11: NiMH battery assembly

Parameter

\begin{tabular}{|c|c|c|}
\hline Parameter & Amount & Sub-Inventory \\
\hline \multicolumn{3}{|l|}{ Functional Unit Output } \\
\hline \multicolumn{3}{|l|}{ NiMH battery, assembled (kg) } \\
\hline \multicolumn{3}{|l|}{ Material Requirements } \\
\hline Positive electrode paste for NiMH battery $(\mathrm{kg})$ & 0.20 & Section 5.3 \\
\hline Negative electrode paste for NiMH battery $(\mathrm{kg})$ & 0.17 & Section 5.2 \\
\hline Positive electrode substrate for NiMH battery (kg) & 0.13 & Section 5.5 \\
\hline Negative electrode substrate for NiMH battery (kg) & 0.11 & Section 5.5 \\
\hline Electrolyte for NiMH battery $(\mathrm{kg})$ & 0.09 & Section 5.4 \\
\hline Separator $(\mathrm{kg})$ & 0.04 & Section 6.2 \\
\hline Cell container, tab and terminals $(\mathrm{kg})$ & 0.10 & Section 6.1 \\
\hline Module and Battery Container (kg) & 0.17 & Section 6.3 \\
\hline Control circuitry $(\mathrm{kg})$ & - & \\
\hline Water, decarbonated & 183 & \\
\hline \multicolumn{3}{|l|}{ Processing and Energy requirements } \\
\hline Electricity, medium voltage, UCTE, at grid (MJ) & 31 & \\
\hline Heat, light fuel oil, at industrial furnace 1MW & 3.4 & \\
\hline Heat, natural gas, industrial furnace low-NOx $>100 \mathrm{~kW}$ & 26 & \\
\hline \multicolumn{3}{|l|}{ Transport Requirements } \\
\hline Freight rail transport (tkm) & 0.10 & \\
\hline Lorry $>16 \mathrm{t}(\mathrm{tkm})$ & 0.03 & \\
\hline \multicolumn{3}{|l|}{ Infrastructure } \\
\hline Facility, precious metal refinery (SE) (unit) & $7.8 \times 10^{-8}$ & \\
\hline \multicolumn{3}{|l|}{ Emissions } \\
\hline Waste heat (MJ) & 31 & \\
\hline
\end{tabular}

Amount Sub-Inventory

$\mathrm{SE}=$ Sweden

\subsection{Production of Negative Electrode Paste for NiMH}

The paste is composed of the electrochemically active $\mathrm{AB}_{5}$ alloy, a binder, and other additives. The $\mathrm{LaNi}_{5}$ compound is the starting point of $\mathrm{AB}_{5}$ alloys (45). In practice however, lanthanum is often substituted by lanthanum-rich mischmetal $(\mathrm{Lm})$, and a fraction of the nickel is often replaced by other metals (Co, Ce, $\mathrm{Mn}, \mathrm{Al}$, etc.) (8, 46). Different alloying techniques have been reported, including mechanical alloying (47), electric arc fusion (48), and radio-frequency induction fusion (49), all under argon atmosphere. To yield small crystal grain sizes, the fusion step is followed by rapid cooling in plate-like casting, gas atomization or melt-spinning $(45,49)$. The resulting alloy is then pulverized, either mechanically or by hydrogen absorption-desorption cycles (48), and mixed with the binder and additives. Commonly used binders include hydroxylpropylmethyl cellulose (HPMC), carboxymethyl cellulose (CMC) and polytetrafluoroethylene (PTFE) (50). Carbon black is commonly added to increase conductivity (8). 
Here, we model an electrode paste containing 3\% CMC, 3\% PTFE, and 2\% carbon black, in accordance with the recommendations of Yang et al. (50) and Ying et al. (8). The rest was made up of mischmetal and nickel, in stoichiometric 1:5 molar ratios. Electric arc fusion was assumed, with the average electricity mix of the UCTE. The electricity requirement was based on the thermodynamic melting of nickel and lanthanum (51). Hydrogen requirements for the absorption-desorption pulverisation were based estimate by Hischier et al. (31). Due to lack of data, no material loss or emissions other than hydrogen and heat were compiled. Energy requirements for grinding and mixing are not expected to be important and were ignored. Requirements of argon atmosphere were omitted due to lack of data. The detailed inventory may be found in Table S12.

Table S12: Inventory for the production of $1 \mathrm{~kg}$ negative electrode paste for $\mathrm{AB}_{5} \mathrm{NiMH}$ battery

\begin{tabular}{lc}
\hline Process & Amount \\
\hline Functional Unit Output & 1 \\
$\quad$ Negative electrode paste for $\mathrm{AB}_{5} \mathrm{NiMH}(\mathrm{kg})$ & \\
Material Requirements & 0.30 \\
Mischmetal (kg) & 0.62 \\
Nickel (kg) & 0.03 \\
Carboxymethyl cellulose (CMC) (kg) & 0.03 \\
Polytetrafluoroethylene (PTFE) (kg) & 0.02 \\
Carbon black (kg) & 0.92 \\
Liquid Hydrogen (kg) & 0.75 \\
Energy and Processing Requirements & \\
Electricity, high voltage, UCTE production mix (MJ) & 0.6 \\
Transport Requirements & 0.1 \\
Freight rail transport, European conditions (tkm) & \\
Lorry >16t, European conditions (tkm) & $4 \times 10^{-10}$ \\
Infrastructure Requirements & \\
Chemical plant (unit) & 0.92 \\
Emissions & 0.75 \\
Hydrogen gas (kg) & \\
Waste heat (MJ) &
\end{tabular}

\subsection{Production of Positive Electrode Paste for NiMH}

The positive electrode material for $\mathrm{NiMH}$ is composed predominantly (ca. 85\%) of nickel II hydroxide $\left(\mathrm{Ni}(\mathrm{OH})_{2}\right)$. It is worth noting that nickel is maintained in its oxidized form, and never goes through the energy-intensive process of being reduced to its metallic form. Nickel powder, cobalt hydroxide $\left(\mathrm{Co}(\mathrm{OH})_{2}\right)$, zinc, graphite or carbon black are often added for performance enhancement. Either carboxymethyl cellulose (CMC) or polytetrafluoroethylene (PTFE) are used as binders $(8,52-54)$. The paste is achieved by simple mixing, with minor energy or processing requirements.

For the purpose of this inventory, a slurry composition of $85 \% \mathrm{Ni}(\mathrm{OH})_{2}, 10 \%$ carbon black, $2.5 \%$ PTFE and 2.5\% CMC was assumed, based on a compromise between the protocols of Liu \& Yu (52) and Ying et al. (8). Direct energy requirements for electrode paste production are negligible. No 
infrastructure use was allocated to this process, as it would be performed on-site at the battery assembly plant. This process being a simple mixing step, no material loss or emissions are expected. The detailed inventory may be found in Table S13.

Table S13: Inventory for the production of $1 \mathrm{~kg}$ of positive electrode material for NiMH battery.

\begin{tabular}{lcc}
\hline Process & Amount & Sub-Inventory \\
\hline Functional Unit Output & \\
Positive Electrode Material for NiMH, at plant $(\mathrm{kg})$ & 1 \\
Material Requirements & \\
Nickel hydroxide $\left(\mathrm{Ni}(\mathrm{OH})_{2}\right)(\mathrm{kg})$ & 0.85 & Section 7.1 \\
Carbon black, GLO $(\mathrm{kg})$ & 0.10 \\
Carboxymethyl cellulose $(\mathrm{CMC})(\mathrm{kg})$ & 0.025 \\
Polytetrafluoroethylene $(\mathrm{PTFE})(\mathrm{kg})$ & 0.025 \\
Transport Requirements & \multicolumn{2}{|}{} \\
Freight rail transport (tkm) & 0.6 \\
Lorry >16t (tkm) & 0.1 \\
\hline
\end{tabular}

$\mathrm{GLO}=$ Global average

\subsection{Production of electrolyte for NiMH battery}

$\mathrm{NiMH}$ batteries rely on a basic aqueous solutions for electrolytes. Based on Ying et al. (8), concentrations of $6 \mathrm{~mol} \cdot \mathrm{L}^{-1}$ of potassium hydroxide $(\mathrm{KOH})$ and $1 \mathrm{~mol} \cdot \mathrm{L}^{-1}$ of lithium hydroxide $(\mathrm{LiOH})$ were assumed. The different masses were calculated using a solution density of $1.3 \mathrm{~kg} \cdot \mathrm{L}^{-1}$ (55). The deionization of water and the salt dissolution were assumed to be performed on-site at the battery assembly plant, and thus no infrastructure requirements were assigned to this process. No material losses or direct emissions are expected. The detailed inventory may be found in Table S14.

Table S14: Inventory for the production of $1 \mathrm{~kg}$ of electrolyte for NiMH battery.

\begin{tabular}{lc}
\hline Process & Amount \\
\hline Functional Unit Output & 1 \\
$\quad$ Electrolyte for NiMH Battery $(\mathrm{kg})$ & \\
Material Requirements & 0.26 \\
$\quad$ Potassium hydroxide $(\mathrm{KOH})(\mathrm{kg})$ & 0.02 \\
Lithium hydroxide $(\mathrm{LiOH})(\mathrm{kg})$ & 0.72 \\
Deionized water $(\mathrm{kg})$ & \\
Transport Requirements & 0.17 \\
Freight rail transport $(\mathrm{tkm})$ & 0.03 \\
$\quad$ Lorry $>16 \mathrm{t}(\mathrm{tkm})$ & \\
\hline
\end{tabular}




\subsection{Production of NiMH electrode substrate}

Typical substrate materials for NiMH negative electrodes include nickel-plated perforated steel sheets, nickel mesh, nickel foam or nickel fiber mats (56). Copper screens were also reported (57). For the positive electrode, the standard option seems to be nickel foam $(8,52-54,58)$. For simplicity, a nickel foam substrate was assumed for both electrodes of the NiMH.

Nickel foam is generally produced by electrodeposition of nickel ions (e.g. $\mathrm{NiSO}_{4}$ ) on polyurethane (PUR) foam. To ensure conductivity, the foam is first covered by a layer of a carbon-based colloid or chemically plated nickel. After the electroplating is complete, the polymer backbone is burned off in air $\left(600^{\circ} \mathrm{C}, 4\right.$ minutes) and the nickel foam is sintered $\left(980^{\circ} \mathrm{C}\right.$ for $\left.40 \mathrm{~min}\right)$ in reductive atmosphere (59).

The relative amounts of nickel and polyurethane were estimated based on the nickel foam density $\left(310 \mathrm{~kg} \cdot \mathrm{m}^{-3}\right)$ reported by Okuno et al. (53) and by assuming a polyurethane density of $6 \mathrm{~kg} \cdot \mathrm{m}^{-3}$. As little information could be found on the emissions and the energy requirements of nickel ion electroplating, metallic nickel was used as a proxy. The energy requirement to heat the nickel mesh to $600^{\circ} \mathrm{C}$ was calculated assuming thermodynamic heating of nickel (51), neglecting both heat losses and any energy released by polyurethane combustion. The energy requirements of the nickel foam sintering step were estimated based on the iron sintering process reported in Ecoinvent (60), as the latter has comparable temperature requirements $\left(\mathrm{ca} .1150^{\circ} \mathrm{C}\right)(61)$. No other aspect of the sintering was modeled. For the emissions resulting from the burning off of polyurethane, polyurethane combustion in a municipal incinerator was used as a proxy. Heat wastes were based on heat requirements. Any other emission was ignored. It is assumed that nickel foam production is outsourced to specialized metallurgy companies by the battery manufacturer (62). The detailed inventory may be found in Table S15.

Table S15: Inventory for the production of $1 \mathrm{~kg}$ of nickel foam electrode substrate for NiMH battery.

\begin{tabular}{lc}
\hline Process & Amount \\
\hline Functional Unit Output & 1 \\
$\quad$ NiMH nickel foam electrode substrate, at plant (kg) & \\
Material Requirements & 1 \\
$\quad$ Nickel, 99.5\%, GLO [proxy for electroplated NiSO4] (kg) & 0.019 \\
$\quad$ Polyurethane, flexible foam (kg) & 0.078 \\
Energy and Processing Requirements & 1.5 \\
$\quad$ Heat, unspecified, in chemical plant [burn-off polyurethane] (MJ) & \\
Heat, unspecified, in chemical plant [sinter] (MJ) & 0.61 \\
Transport Requirements & 0.20 \\
$\quad$ Freight rail transport (tkm) & \\
Lorry >16t (tkm) & $4.0 x 10^{-10}$ \\
Infrastructure Requirements & \\
Chemical plant, organics (unit) & 0.019 \\
Emissions & 1.58 \\
$\quad$ Disposal of Polyurethane to municipal incinerator, [proxy for combustion], CH (kg) \\
Waste heat (MJ)
\end{tabular}

$\mathrm{GLO}=$ Global average 


\section{Inventory of common components production}

\subsection{Production of cell containers}

The cell containers for lithium-ion batteries will generally be made of aluminum, though stainless steel is sometimes used (4). For NiMH, stainless steel is the preferred option (7), possibly due to its higher resistance to corrosion attack from the basic electrolyte (51). Having no specific data on the container production, this process was inventoried with metal sheet rolling as a proxy. The detailed inventory may be found in Table S16.

Table S16: Inventories for the production of $1 \mathrm{~kg}$ of cell containers for $\mathrm{Li}$-ion or NiMH.

\begin{tabular}{lc}
\hline Process & Amount \\
\hline Functional Unit Output & \\
$\quad$ Cell container (Li-ion or NiMH), at plant $(\mathrm{kg})$ & 1 \\
Material Requirements & \\
$\quad$ Cell container, li-ion: Aluminium, production mix $(\mathrm{kg})$ & 1 \\
Cell container, NiMH: Chromium steel $18 / 8(\mathrm{~kg})$ & \\
Energy and Processing Requirements & \\
Cell container, li-ion: Sheet rolling, aluminum $(\mathrm{kg})$ & 1 \\
Cell container, NiMH: Sheet rolling, steel $(\mathrm{kg})$ & \\
Transport Requirements & 0.2 \\
Freight rail transport (tkm) & 0.1 \\
Lorry $>16 t$ (tkm) & \\
Infrastructure Requirements & $4.6 \times 10^{-10}$ \\
Metal working factory (unit) & \\
\hline
\end{tabular}

\subsection{Production of separator}

The fundamental role of the separator is to prevent the two electrodes from touching, while letting electrons in the electrolyte flow with as little resistance as possible. Li-ion and NiMH separators are both typically made of porous polymer. For $\mathrm{NiMH}$, materials such as non-woven polyamide (56), sulphonated polypropylene fabric (53), non-woven PVC cloth (58), polypropylene (PP) and polyethylene (PE) (63) have been reported. Similarly, Li-ion cells generally rely on polypropylene and polyethylene $(4,30,64)$. Other materials being researched include polyacrylonitrile (PAN) and ceramic composite based non-woven polyolefins, along with hydrophilic $\mathrm{SiO}_{2}$ powder (13).

In this study, we modeled in the same manner the separator for both Li-ion and NiMH batteries. It was assumed to be composed of PP and PE, in equal amounts. Injection molding was used as a proxy to model the processing of the materials. No material losses were accounted for. 
Table S17: Production of $1 \mathrm{~kg}$ of separator for $\mathrm{Li}$-ion or $\mathrm{NiMH}$ batteries

\begin{tabular}{lc}
\hline Process & Amount \\
\hline Functional Unit Output & 1 \\
$\quad$ Separator material for Li-ion or NiMH $(\mathrm{kg})$ & \\
Material Requirements & 0.5 \\
$\quad$ Polyethylene, LDPE granulate, at plant $(\mathrm{kg})$ & 0.5 \\
$\quad$ Polypropylene, granulate, at plant $(\mathrm{kg})$ & \\
Energy and Processing Requirements & \\
$\quad$ Injection moulding (kg) & \\
Transport Requirements & 0.2 \\
$\quad$ Freight rail transport (tkm) & 0.1 \\
$\quad$ Lorry $>16 t$ (tkm) & \\
Infrastructure Requirements & $7.4 \times 10^{-10}$ \\
$\quad$ Plastic processing factory & \\
\hline
\end{tabular}

\subsection{Production of module and battery packing}

Multiple cells are combined together as modules, which are in turn combined in battery packs. Plastics are usually the dominant material in module and battery packs, since they are resistant to corrosion, inexpensive, and light (4). For this inventory, we combined as one entity the packing for the modules and the battery pack, and used polyethylene terephthalate (PET) for both. The inventory for this process was compiled in Table S18.

Table S18: Production of $1 \mathrm{~kg}$ of module and battery packing

\begin{tabular}{lc}
\hline Process & Amount \\
\hline Functional Unit Output & \\
$\quad$ Module and battery packing & 1 \\
Material Requirements & \\
$\quad$ Polyethylene terephthalate & 1 \\
Energy and Processing Requirements & 1 \\
$\quad$ Injection moulding (kg) & \\
Transport Requirements & 0.2 \\
$\quad$ Freight rail transport (tkm) & 0.1 \\
$\quad$ Lorry $>16 t$ (tkm) & \\
Infrastructure Requirements & $7.4 \times 10^{-10}$ \\
$\quad$ Plastic processing factory & \\
\hline
\end{tabular}

\section{Inventory intermediate materials production}

\subsection{Production of transition metal hydroxides}

Nickel hydroxide $\left(\mathrm{Ni}(\mathrm{OH})_{2}\right)$ and $\mathrm{Ni}_{0.4} \mathrm{Co}_{0.2} \mathrm{Mn}_{0.4}(\mathrm{OH})_{2}$ are starting materials of the positive electrode pastes of NiMH and NCM Li-ion batteries, respectively. Their production process consists in the precipitation of the metal hydroxides from an aqueous solution of the metal salts by reaction with a 
strong base $(12,15,65)$. The products are recuperated by filtration and dried at low temperature (ca. $120^{\circ} \mathrm{C}$ ) in air. For this inventory, the sulphate salt of each metal was used in combination with sodium hydroxide (eq. 6 and 7). This simple mixture and precipitation step is not expected to have significant energy requirements. As these metal hydroxides are virtually insoluble in alkaline solutions (55), no product loss was accounted for.

$$
\begin{gathered}
\mathrm{NiSO}_{4(\mathrm{aq})}+2 \mathrm{NaOH}_{(\mathrm{aq})} \rightarrow \mathrm{Ni}(\mathrm{OH})_{2(\mathrm{~s})}+\mathrm{Na}_{2} \mathrm{SO}_{4(\mathrm{aq})} \\
0.4 \mathrm{NiSO}_{4}+0.2 \mathrm{CoSO}_{4}+0.4 \mathrm{MnSO}_{4}+2 \mathrm{NaOH} \rightarrow \mathrm{Ni}_{0.4} \mathrm{Co}_{0.2} \mathrm{Mn}_{0.4}(\mathrm{OH})_{2}+\mathrm{Na}_{2} \mathrm{SO}_{4}
\end{gathered}
$$

Table S19: Inventories for the production of $1 \mathrm{~kg}$ of $\mathrm{Ni}(\mathrm{OH})_{2}$.

\begin{tabular}{lcc}
\hline Process & Amount & Sub-Inventory \\
\hline Functional Unit Output & & \\
$\quad$ Nickel hydroxide $\left(\mathrm{Ni}(\mathrm{OH})_{2}\right)(\mathrm{kg})$ & 1 \\
Material Requirements & 1.67 & Section 7.2 \\
$\quad$ Nickel sulphate $\left(\mathrm{NiSO}_{4}\right)(\mathrm{kg})$ & 0.86 \\
$\quad$ Sodium hydroxide $(\mathrm{NaOH})(\mathrm{kg})$ & \\
Transport Requirements & 1.5 \\
$\quad$ Freight rail transport $(\mathrm{tkm})$ & 0.25 \\
$\quad$ Lorry $>16 \mathrm{t}(\mathrm{tkm})$ & \\
Infrastructure Requirements & $4.6 \times 10^{-10}$ \\
$\quad$ Chemical plant, organics (unit) & \\
Emissions & \multicolumn{2}{c}{1.5} \\
$\quad$ Sodium sulphate $\left(\mathrm{Na}_{2} \mathrm{SO}_{4}\right)(\mathrm{kg})$ & \\
\hline
\end{tabular}

Table S20: Inventories for the production of $1 \mathrm{~kg}$ of $\mathrm{Ni}_{0.4} \mathrm{Co}_{0.2} \mathrm{Mn}_{0.4}(\mathrm{OH})_{2}$.

\section{Process}

Amount Sub-Inventory

Functional Unit Output

Nickel cobalt manganese hydroxide $\left(\mathrm{Ni}_{0.4} \mathrm{Co}_{0.2} \mathrm{Mn}_{0.4}(\mathrm{OH})_{2}\right)(\mathrm{kg})$

1

Material Requirements

Nickel sulphate $\left(\mathrm{NiSO}_{4}\right)(\mathrm{kg})$

$0.68 \quad$ Section 7.2

Cobalt sulphate $\left(\mathrm{CoSO}_{4}\right)(\mathrm{kg})$

$0.34 \quad$ Section 7.2

Manganese sulphate $\left(\mathrm{MnSO}_{4}\right)(\mathrm{kg})$

$0.66 \quad$ Section 7.3

Sodium hydroxide $(\mathrm{NaOH})(\mathrm{kg})$

0.88

Transport Requirements

Freight rail transport (tkm)

Lorry $>16 \mathrm{t}(\mathrm{tkm})$

Infrastructure Requirements

Chemical plant, organics (unit)

$4.6 \times 10^{-10}$

Emissions

Sodium sulphate $\left(\mathrm{Na}_{2} \mathrm{SO}_{4}\right)(\mathrm{kg})$

1.5 


\subsection{Production of $\mathrm{NiSO}_{4}$ and $\mathrm{CoSO}_{4}$}

Most of the nickel sulphate on the market is a by-product of electrolytic copper refining (65). Similarly, cobalt sulphate is frequently acquired as a by-product of nickel and copper leaching (e.g. Gécamines process) (66). These three metals are mined jointly in sulfidic ores (67). Both $\mathrm{NiSO}_{4}$ and $\mathrm{CoSO}_{4}$ are typically intermediates in the process of refining metallic nickel and cobalt by electrowinning. They are produced by sulphuric acid leaching of ore concentrates or sulfidic matte. As they have not yet undergone the energy intensive reduction step to the neutral metal, nickel and cobalt sulphates have a lower energy requirement than their neutral metallic counterparts.

No inventory could be found detailing the production of $\mathrm{NiSO}_{4}$ or $\mathrm{CoSO}_{4}$. Their production requirements were rather approximated by modifying the inventories for primary nickel and cobalt metals in Ecoinvent. By removing any reduction, carbonyl reaction or electrorefining step, these modified processes thus conceptually yield metal ions rather than neutral metal. This approximation is certainly crude, but constitutes an improvement relative to using metals as a direct proxy for metal sulphate salts.

The Ecoinvent inventory of nickel production is a relatively detailed combination of five commonly used industrial paths (60). These paths were separated, and the steps refining nickel beyond the $\mathrm{NiSO}_{4}$ intermediate were eliminated. All requirements pertaining to ore mining, beneficiation, drying, roasting, and primary smelting were conserved, as were matte conversion and separation of co-products (both wet and dry). All requirements linked to primary refining, nickel refining, reduction, and carbonyl reaction were removed. This new process thus constitutes an "intermediate process", with unrefined metal ions as output. No information allowed for a disaggregation of the emissions and the waste disposals between the pre-reduction and the reduction phase. Consequently, emission and waste disposal requirements were not modified.

Evidently, nickel ions must undergo processing in going from crude ionic solution to pure $\mathrm{NiSO}_{4}$ crystals. These would include matte leaching in the case of dry co-product separation, crystallization, and possibly recrystallization. Relative to the whole metallurgy process, these processes are not expected to have high energy requirements. They were not accounted for in this inventory due to lack of data. The sulphuric acid requirements for $\mathrm{NiSO}_{4}$ production were ignored. The production of $\mathrm{H}_{2} \mathrm{SO}_{4}$ as a by-product of sulfidic ore metallurgy far outweighs the leaching requirements, and Ecoinvent does not account quantitatively for this output.

As recognized by Hischier (68), the process description for cobalt production in Ecoinvent is not as detailed and exhaustive as that of nickel. Nevertheless, it is clearly stated which requirements are made necessary by the reduction step. These were removed from the inventory of $\mathrm{CoSO}_{4} \cdot$ Emissions, waste disposal and sulphuric acid requirements were dealt with in the same way as for $\mathrm{NiSO}_{4}$. 
Table S21: Inventories for the production of $1 \mathrm{~kg}$ of $\mathrm{NiSO}_{4}$, produced by modifying the Ecoinvent inventory for class I nickel.

\begin{tabular}{|c|c|c|}
\hline Process & $\begin{array}{l}\text { Modification from } \\
\text { metallic nickel in } \\
\text { Ecoinvent }\end{array}$ & $\begin{array}{l}\text { Inventory for production } \\
\text { of } \mathrm{NiSO}_{4}\end{array}$ \\
\hline \multicolumn{3}{|l|}{ Functional Unit Output } \\
\hline & $\begin{array}{l}\text { Modifications for } 379.3 \mathrm{~g} \\
\text { of } \mathrm{Ni}^{0} \text { metal to } \mathrm{Ni}^{++}\end{array}$ & $1 \mathrm{~kg} \mathrm{NiSO}_{4}\left(379.3 \mathrm{~g} \mathrm{Ni}^{2+}\right)$ \\
\hline \multicolumn{3}{|l|}{ Material Requirements } \\
\hline Ammonia, liquid, at regional storehouse (kg) & - & 0.032 \\
\hline Chemicals inorganic $(\mathrm{kg})$ & - & 0.023 \\
\hline Chemicals organic (kg) & - & 0.0068 \\
\hline Hydrogen cyanide (kg) & - & 0.0011 \\
\hline Hydrogen liquid (kg) & -0.0017 & - \\
\hline Limestone, milled, packed (kg) & - & 0.73 \\
\hline Portland calcareous cement $(\mathrm{CH})(\mathrm{kg})$ & - & 1.0 \\
\hline Sand, at mine $(\mathrm{CH})(\mathrm{kg})$ & - & 13 \\
\hline Silica sand $(\mathrm{kg})$ & - & 0.72 \\
\hline \multicolumn{3}{|l|}{ Energy and Processing Requirements } \\
\hline Blasting (kg) & - & 0.046 \\
\hline Diesel, burned in building machine (GLO) (MJ) & - & 3.1 \\
\hline Electricity, high voltage, UCTE (MJ) & -1.0 & 4.1 \\
\hline Electricity, hydropower, at run-of-river (MJ) & -1.5 & 10.5 \\
\hline Electricity, medium voltage, UCTE (MJ) & - & 1.7 \\
\hline Heat, hard coal, industrial furnace 1-10 MW (MJ) & - & 0.71 \\
\hline Heavy fuel oil, burned in industrial furnace $1 \mathrm{MW}(\mathrm{MJ})$ & -0.46 & 8.1 \\
\hline Natural gas, burned in industrial furnace > $100 \mathrm{~kW}(\mathrm{MJ})$ & -2.0 & 3.5 \\
\hline \multicolumn{3}{|l|}{ Transport Requirements } \\
\hline Lorry $>16 \mathrm{t}(\mathrm{tkm})$ & - & 0.68 \\
\hline \multicolumn{3}{|l|}{ Infrastructure Requirements } \\
\hline Non-ferrous metal mine, underground (GLO) (unit) & - & $1.5 \times 10^{-9}$ \\
\hline Non-ferrous metal smelter (GLO) (unit) & - & $1.3 \times 10^{-11}$ \\
\hline Aluminium hydroxide plant (unit) & - & $2.5 \times 10^{-10}$ \\
\hline Conveyor belt $\left(\mathrm{m}^{3}\right)$ & - & $1.2 \times 10^{-6}$ \\
\hline \multicolumn{3}{|l|}{ Waste Disposal } \\
\hline $\begin{array}{l}\text { Disposal, nickel smelter slag, } 0 \% \text { water, residual material } \\
\text { landfill }(\mathrm{CH})(\mathrm{kg})\end{array}$ & - & 3.6 \\
\hline Disposal, sulfidic tailings, off-site (GLO) $(\mathrm{kg})$ & - & 27 \\
\hline
\end{tabular}

$\mathrm{CH}=$ Switzerland, $\mathrm{GLO}=$ Global average 
Table S22: Inventories for the production of $1 \mathrm{~kg}$ of $\mathrm{CoSO}_{4}$, produced by modifying the Ecoinvent inventory for primary cobalt

\begin{tabular}{|c|c|c|}
\hline Process & $\begin{array}{l}\text { Modification from } \\
\text { metallic cobalt in } \\
\text { Ecoinvent }\end{array}$ & $\begin{array}{c}\text { Inventory for } \\
\text { production of } \mathrm{CoSO}_{4}\end{array}$ \\
\hline \multicolumn{3}{|l|}{ Functional Unit Output } \\
\hline & $\begin{array}{l}\text { Modifications for } 380.2 \mathrm{~g} \\
\text { of } \mathrm{Co}^{0} \text { metal to } \mathrm{Co}^{2+}\end{array}$ & $\begin{array}{c}1 \mathrm{~kg} \mathrm{CoSO}_{4} \\
\left(380.2 \mathrm{gCo}^{2+}\right)\end{array}$ \\
\hline \multicolumn{3}{|l|}{ Material Requirements } \\
\hline Carbon monoxide (kg) & -0.11 & - \\
\hline Chemicals inorganic, at plant (GLO) (kg) & - & 0.032 \\
\hline Chemicals organic, at plant (GLO) (kg) & - & 0.010 \\
\hline Hydrogen cyanide, at plant $(\mathrm{kg})$ & - & 0.0015 \\
\hline Hydrogen, liquid, at plant (kg) & -0.0079 & - \\
\hline Limestone, milled, packed, at plant $(\mathrm{CH})(\mathrm{kg})$ & - & 0.019 \\
\hline Portland calcareous cement, at plant $(\mathrm{CH})(\mathrm{kg})$ & - & 1.4 \\
\hline Sand, at mine $(\mathrm{CH})(\mathrm{kg})$ & - & 17 \\
\hline \multicolumn{3}{|l|}{ Energy and Processing Requirements } \\
\hline Blasting (kg) & -0.11 & 0.063 \\
\hline Diesel, burned in building machine (GLO) (MJ) & - & 4.6 \\
\hline Electricity, medium voltage, production UCTE (MJ) & - & 6.4 \\
\hline Heat, natural gas, at industrial furnace $>100 \mathrm{~kW}(\mathrm{MJ})$ & -0.76 & - \\
\hline Transport Requirements & - & \\
\hline Lorry $>16 \mathrm{t}(\mathrm{tkm})$ & - & 0.94 \\
\hline \multicolumn{3}{|l|}{ Infrastructure Requirements } \\
\hline Aluminium hydroxide, plant (unit) & - & $3.4 \times 10^{-10}$ \\
\hline Conveyor belt, at plant $\left(\mathrm{m}^{3}\right)$ & - & $1.6 \times 10^{-6}$ \\
\hline Non-ferrous metal mine, underground (GLO) (unit) & - & $2.1 \times 10^{-9}$ \\
\hline \multicolumn{3}{|l|}{ Waste Disposal } \\
\hline $\begin{array}{l}\text { Disposal, nickel smelter slag, } 0 \% \text { water, residual material } \\
\text { landfill }(\mathrm{CH})(\mathrm{kg})\end{array}$ & & 13 \\
\hline Disposal, sulfidic tailings, off-site (GLO) $(\mathrm{kg})$ & & 25 \\
\hline
\end{tabular}

$\mathrm{CH}=$ Switzerland, GLO $=$ Global average 
Table S23: Direct emissions for the production of $1 \mathrm{~kg}$ of NiSO4 and $1 \mathrm{~kg}$ of CoSO4, based on Ecoinvent emission inventories of metallic nickel and cobalt production

\begin{tabular}{|c|c|c|c|}
\hline Emissions & Compartment & $\mathrm{NiSO}_{4}$ & $\mathrm{CoSO}_{4}$ \\
\hline $\begin{array}{l}\text { Nickel, } 1.13 \% \text { in sulphide, } \mathrm{Ni} 0.76 \% \text { and } \mathrm{Cu} 0.76 \% \text { in crude ore, in ground } \\
(\mathrm{kg})\end{array}$ & Raw & $4.8 \times 10^{-1}$ & - \\
\hline Cobalt, in ground $(\mathrm{kg})$ & Raw & - & $5.0 \times 10^{-1}$ \\
\hline Water, river $\left(\mathrm{m}^{3}\right)$ & Raw & $1.1 \times 10^{-2}$ & $1.4 \times 10^{-2}$ \\
\hline Water, well, in ground $\left(\mathrm{m}^{3}\right)$ & Raw & $6.1 \times 10^{-2}$ & $8.4 \times 10^{-2}$ \\
\hline Aluminum $(\mathrm{kg})$ & Air & $5.6 \times 10^{-4}$ & - \\
\hline Arsenic $(\mathrm{kg})$ & Air & $2.0 \times 10^{-6}$ & - \\
\hline Calcium $(\mathrm{kg})$ & Air & $3.9 \times 10^{-4}$ & - \\
\hline Carbon dioxide, fossil $(\mathrm{kg})$ & Air & $3.2 \times 10^{-1}$ & - \\
\hline Carbon disulphide $(\mathrm{kg})$ & Air & $3.0 \times 10^{-3}$ & $4.2 \times 10^{-3}$ \\
\hline Cobalt $(\mathrm{kg})$ & Air & $4.2 \times 10^{-4}$ & - \\
\hline Copper $(\mathrm{kg})$ & Air & $1.3 \times 10^{-4}$ & - \\
\hline Dioxins, measured as 2,3,7,8-tetrachlorodibenzo-p-dioxin $(\mathrm{kg})$ & Air & $3.5 \times 10^{-12}$ & - \\
\hline Heat, waste (MJ) & Air & $2.0 \times 10^{1}$ & $6.4 \times 10^{0}$ \\
\hline Lead $(\mathrm{kg})$ & Air & $1.2 \times 10^{-5}$ & - \\
\hline Magnesium (kg) & Air & $3.3 \times 10^{-4}$ & - \\
\hline Nickel $(\mathrm{kg})$ & Air & $1.5 \times 10^{-4}$ & - \\
\hline NMVOC, non-methane volatile organic compounds, unspecified origin $(\mathrm{kg})$ & Air & $6.9 \times 10^{-5}$ & - \\
\hline Particulates, $<2.5$ um $(\mathrm{kg})$ & Air & $5.7 \times 10^{-3}$ & $7.5 \times 10^{-4}$ \\
\hline Particulates, > $10 \mathrm{um}(\mathrm{kg})$ & Air & $5.8 \times 10^{-4}$ & $7.7 \times 10^{-3}$ \\
\hline Particulates, $>2.5 \mathrm{um}$, and $<10 \mathrm{um}(\mathrm{kg})$ & Air & $5.0 \times 10^{-3}$ & $6.7 \times 10^{-3}$ \\
\hline Silver $(\mathrm{kg})$ & Air & $4.8 \times 10^{-8}$ & - \\
\hline Sulphur dioxide (kg) & Air & $5.1 \times 10^{-1}$ & - \\
\hline $\operatorname{Tin}(\mathrm{kg})$ & Air & $2.3 \times 10^{-6}$ & - \\
\hline Zinc $(\mathrm{kg})$ & Air & $3.5 \times 10^{-5}$ & - \\
\hline Aluminium (kg) & Water & $5.2 \times 10^{-6}$ & $7.2 \times 10^{-6}$ \\
\hline Arsenic, ion $(\mathrm{kg})$ & Water & $2.6 \times 10^{-7}$ & $2.5 \times 10^{-7}$ \\
\hline BOD5, Biological Oxygen Demand (kg) & Water & $6.3 \times 10^{-4}$ & - \\
\hline Cadmium, ion $(\mathrm{kg})$ & Water & $3.1 \times 10^{-8}$ & $2.6 \times 10^{-8}$ \\
\hline Calcium, ion $(\mathrm{kg})$ & Water & $1.3 \times 10^{-2}$ & $5.7 \times 10^{-2}$ \\
\hline Calcium, ion $(\mathrm{kg})$ & Water & $2.9 \times 10^{-2}$ & - \\
\hline Chromium, ion $(\mathrm{kg})$ & Water & $1.6 \times 10^{-7}$ & $4.6 \times 10^{-8}$ \\
\hline Cobalt $(\mathrm{kg})$ & Water & $4.7 \times 10^{-8}$ & $6.5 \times 10^{-8}$ \\
\hline COD, Chemical Oxygen Demand (kg) & Water & $6.3 \times 10^{-4}$ & $8.7 \times 10^{-4}$ \\
\hline Copper, ion $(\mathrm{kg})$ & Water & $7.1 \times 10^{-7}$ & $6.7 \times 10^{-7}$ \\
\hline Cyanide $(\mathrm{kg})$ & Water & $1.1 \times 10^{-4}$ & $1.6 \times 10^{-4}$ \\
\hline DOC, Dissolved Organic Carbon (kg) & Water & $2.5 \times 10^{-4}$ & - \\
\hline Iron, ion $(\mathrm{kg})$ & Water & $1.8 \times 10^{-5}$ & $2.4 \times 10^{-5}$ \\
\hline Lead $(\mathrm{kg})$ & Water & $2.4 \times 10^{-7}$ & $2.3 \times 10^{-7}$ \\
\hline Manganese (kg) & Water & $1.5 \times 10^{-6}$ & $2.1 \times 10^{-6}$ \\
\hline Mercury $(\mathrm{kg})$ & Water & $3.5 \times 10^{-9}$ & $3.2 \times 10^{-9}$ \\
\hline Nickel, ion (kg) & Water & $1.6 \times 10^{-6}$ & $2.0 \times 10^{-6}$ \\
\hline Nitrogen, organic bound $(\mathrm{kg})$ & Water & $1.4 \times 10^{-3}$ & - \\
\hline Nitrogen $(\mathrm{kg})$ & Water & - & $1.9 \times 10^{-3}$ \\
\hline Solved solids (kg) & Water & $3.1 \times 10^{-4}$ & $4.3 \times 10^{-4}$ \\
\hline Sulphate $(\mathrm{kg})$ & Water & $1.4 \times 10^{-1}$ & $2.0 \times 10^{-1}$ \\
\hline Tin, ion $(\mathrm{kg})$ & Water & $1.2 \times 10^{-7}$ & - \\
\hline TOC, Total Organic Carbon (kg) & Water & $2.5 \times 10^{-4}$ & - \\
\hline Zinc, ion $(\mathrm{kg})$ & Water & $5.0 \times 10^{-6}$ & $6.4 \times 10^{-6}$ \\
\hline
\end{tabular}




\subsection{Production of $\mathrm{MnSO}_{4}$}

Similarly to $\mathrm{NiSO}_{4}$ and $\mathrm{CoSO}_{4}$, manganese II sulphate $\left(\mathrm{MnSO}_{4}\right)$ is an intermediate in the electrolytic (hydrometallurgy) route to metallic manganese production (69). Manganese ore is typically insoluble and predominantly in +4 oxidation state (e.g. $\mathrm{MnO}_{2}$ ). Manganese carbonates constitute an exception, and can be leached directly. In other cases, the ore is calcinated at ca. $850-1000^{\circ} \mathrm{C}$ under reducing atmosphere to yield the manganese II oxide (MnO) intermediate. Anthracite, coal, charcoal, hydrocarbon oils, natural gas, coal gas and liquefied petroleum gas are used in different proportions as sources of carbon, which is the reducing reagent of choice. Following reduction, $\mathrm{MnO}$ is then finely ground and leached with a 2-5\% $\mathrm{H}_{2} \mathrm{SO}_{4}$ solution. Other metals are removed from solution by air oxidation (iron), $\mathrm{pH}$ manipulations, and soluble sulphide dissolution. Manganese sulphate concentrations in solution typically reaches $10 \%$ (69). In the metallurgy route, the manganese would then be reduced to its metallic form by cathodic deposition. To obtain the salt intermediate, the manganese sulphate must be crystallized out of solution, and possibly recrystallized.

No inventory could be found for the production of $\mathrm{MnSO}_{4}$. The inventory for manganese metal production in Ecoinvent could not be used as a starting point. As recognized by Classen et al. (60), the precision and completeness of this process description is very low. In fact, the electricity requirement for the hydrolytic reduction of manganese ions is the only significant distinction between this process and the manganese ore concentrate; all material requirements and emissions being omitted.

Here we provide a crude model of $\mathrm{MnSO}_{4}$ production. Though limited and based on estimations, it represents nonetheless an improvement relative to using manganese concentrate or manganese metal as proxies. Manganese concentrate was assumed to contain $42 \%$ manganese, consistent with world average concentration (60). A leaching efficiency of $90 \%$ is consistent with current practices (70). We further assume a $90 \%$ crystallization efficiency. The fuel requirements for the reductive calcination of manganese IV dioxide were estimated to equal that of iron sintering, which operates at similar temperatures. The grinding energy requirements were of $20 \mathrm{kWh}$ per metric ton of processed ore (60). Sulphuric acid use was determined stoichiometrically. Energy requirements for crystallization, which should be relatively unimportant, were not modeled due to lack of data. Direct emissions, which may be substantial, were omitted for the same reasons. 
Table S24: Inventory for the production of $1 \mathrm{~kg}$ of $\mathrm{MnSO}_{4}$

\section{Process}

\section{Amount}

Functional Unit Output

Manganese sulphate, at plant $\left(\mathrm{MnSO}_{4}\right)(\mathrm{kg})$

1

Material Requirements

Manganese concentrate, at beneficiation (GLO) (kg) 1.1

$\begin{array}{lr}\text { Sulphuric acid, liquid, at plant }(\mathrm{kg}) & 0.65\end{array}$

Energy and Processing Requirements

$\begin{array}{lr}\text { Natural gas, high pressure, at consumer (MJ) } & 0.036\end{array}$

Hard coal coke, at plant (MJ) $\quad 1.43$

Electricity, medium voltage, production UCTE, at grid (MJ) $\quad 0.077$

Transport Requirements

$\begin{array}{ll}\text { Freight rail transport, European conditions (tkm) } & 0.39\end{array}$

$\begin{array}{lr}\text { Lorry }>16 \mathrm{t}(\mathrm{tkm}) & 0.06\end{array}$

Infrastructure Requirements

Non-ferrous metal mine, underground (GLO) (unit) $1.6 \times 10^{-14}$

Aluminium hydroxide plant (unit) $\quad 2.4 \times 10^{-10}$

Waste and Emissions

Disposal, non-sulfidic tailings, off-site (GLO) (kg) $\quad 0.71$

Waste heat, to air (MJ)

1.5

GLO = Global average

\section{Energy requirements of production phase}

\subsection{Energy scoping}

While material requirement estimates could generally be guided by dismantling reports or mass balance considerations, quantifying energy requirements in a process-wise manner proved challenging. No public report could be found in which a battery producer directly disclosed its energy requirements in a sufficiently detailed manner. This lead us to employ a top-down approach, using reported industry overall energy requirements, as reviewed in Table S25.

Amongst the different estimates, we considered the values reported by Rydh and Sanden (26) to be most credible, partly because Carl Johan Rydh has worked for SAFT (battery company), partly because their publication focuses precisely on energy use, and partly because their estimates have been used in other energy and LCA publications, e.g. Samaras and Meisterling (71). They claim that their reported "Manufacture" energy requirement covers all requirements from virgin material to final product. 
Table S25: Review of overall energy requirements reported for battery production,all expressed as MJ per kg of battery

\begin{tabular}{|c|c|c|c|c|c|c|c|}
\hline \multirow{2}{*}{ Type } & \multirow{2}{*}{\multicolumn{2}{|c|}{$\begin{array}{c}\text { Production } \\
\text { Year }\end{array}$}} & \multicolumn{2}{|c|}{ Energy Requirements $\left(\mathbf{M J} \cdot \mathrm{kg}^{-1}\right)$} & \multicolumn{2}{|c|}{ Covers } & \multirow{2}{*}{ Notes } \\
\hline & & & Primary & Absolute & Materials & Manufacture & \\
\hline \multirow[t]{6}{*}{ Li-ion } & $\mathrm{a}$ & $<1999$ & & $\mathrm{El}: 54.6$ & - & $\mathrm{X}$ & Only covers electricity \\
\hline & $\mathrm{b}$ & $2002-2003$ & & 288 (El: 148, Gas: 123, Oil:16) & - & $\mathrm{X}$ & For laptop use \\
\hline & $\mathrm{c}$ & $<2003$ & $96-144^{*}$ & & - & $\mathrm{X}$ & For static application \\
\hline & $\mathrm{c}$ & $<2003$ & $149-224^{*}$ & & $\mathrm{X}$ & $\mathrm{X}$ & For static application \\
\hline & $\mathrm{d}$ & $<2009$ & & 1.40 & & $\mathrm{X}$ & \\
\hline & d & $<2009$ & 104 & & $X$ & $\mathrm{X}$ & Whole life cycle \\
\hline \multirow[t]{4}{*}{ NiMH } & $\mathrm{e}$ & 1996 & & 10.3 (El: 1.96, Gas: 8.35) & - & $\mathrm{X}$ & \\
\hline & $\mathrm{c}$ & $<2003$ & $74-139^{* *}$ & & - & $\mathrm{X}$ & For static application \\
\hline & $\mathrm{c}$ & $<2003$ & $128-241^{* *}$ & & $\mathrm{X}$ & $\mathrm{X}$ & For static application \\
\hline & $\mathrm{b}$ & $2002-2003$ & & 144 (El: 77, Gas:59, Oil: 8) & - & $\mathrm{X}$ & Battery for laptop use \\
\hline
\end{tabular}

* $75 \%$ of primary energy for electricity production, with assumed conversion efficiency to electricity of $35 \%$

** $68 \%$ of primary energy for electricity production with assumed conversion efficiency to electricity of $35 \%$

a Almemark et al. (72); based on Japanese CRIEPI data

b Hischier et al. (31); Ecoinvent 2.1, based on Maxell 2003 environmental report

c Rydh and Sandén (26); d Notter et al. (73); e Rantik (74);

\subsection{Energy Mix}

Rydh and Sandén (26) report that $75 \%$ of the primary energy requirements of battery manufacture are attributable to electricity consumption, with a $35 \%$ conversion efficiency from primary fuel to electricity. We assume that the remainder $25 \%$ of the primary energy requirements are fulfilled directly by fossil fuel combustion for heat production or in machinery, with nearly $100 \%$ "conversion" efficiency. Thus, in terms of "direct" energy requirements, electricity and fossil fuel would each fulfill roughly $50 \%$ of the energy bill. This energy mix is in agreement with overall reported figures reported by Saft (75) and Maxell (76) industries. For this inventory, we use the following energy mix for direct inputs to the battery manufacturing process: $51.7 \%$ electricity, $42.7 \%$ heat from natural gas combustion and 5.5\% heat from light fuel oil. This ratio was inspired by the Maxell (76) environmental report. The electricity mix was taken to be the average mix of the Union for the Coordination of Transmission of Electricity (UCTE).

\subsection{Energy inventory}

As mentioned above, we took a top-down approach to cover all energy requirements related to manufacture of the battery. From this overall total, we then tried to bring a more detailed perspective by "separating out" the known energy requirements for specific battery manufacturing processes.

For production from cradle to gate, using virgin materials, Rydh and Sandén (26) estimated total primary fuel requirements of $1.87 \mathrm{MJ} \cdot \mathrm{kWh}^{-1}$ of Li-ion capacity, and 3.7 $\mathrm{MJ}^{\mathrm{kWW}} \mathrm{kW}^{-1}$ of NiMH capacity. Of this total, 1.2 $\mathrm{MJ} \cdot \mathrm{kWh}^{-1}$ and 2.1 $\mathrm{MJ}_{\mathrm{kWh}} \mathrm{kWe}^{-1}$ wedicated to "manufacturing" of Li-ion and $\mathrm{NiMH}$, respectively; the rest being required for virgin material production. The problem remains the concept of "manufacture" is not a very clearly defined system boundary. In particular, it is not explicitly stated at 
which level of refinement a process ceases to belong to "material production" and falls over to "manufacturing". For this paper, we define the modification of any material beyond its elemental or uncomplicated state to belong to "manufacturing"; Rydh and Sandén's "material production" is interpreted as being limited to pure metals, simple plastics, or raw chemicals. We are comforted in this interpretation by a certain number of elements in the Rydh and Sandén study. First, it is an implicit requirement of their model that the production of any non-manufactured material must be possible either by recycling or by production of virgin material, which is certainly not the case for complicated chemicals or components. Secondly, the PhD thesis of Rydh (77) helps put the present energy analysis in context by relating it to other papers. In this thesis, we learn that the energy requirements for material production were based on the grouped LCI data that lead to the publication by Rydh and Sun (78), which only covers pure or simple materials. In the PhD thesis, it is also emphasized that the energy study in question is partly based on the environmental assessment of vanadium redox and lead-acid batteries by Rydh (79), for which all material requirements (explicitly listed) are either pure metals or simple chemicals. A similar treatment of "raw materials" is observed in the study of $\mathrm{NiCd}$ portable batteries by Rydh and Karlstrom (80).

Table S26 summarizes what processes we include in this overall "battery manufacturing" energy use. Thus, for processes included in the overall battery manufacturing (Table S26, first column), any additional energy requirement identified would be separated out of the overall top-down energy requirement. Additional process-specific details were estimated based on published estimates, industrial process modeling, thermodynamic calculations, or the use of proxies (Table S26, last 4 columns). 
Table S26: Overview of strategies pursued and assumptions used to quantify the energy requirements for the production of the different battery sub-components and materials.

\begin{tabular}{|c|c|c|c|c|c|}
\hline \multirow[b]{2}{*}{ Process } & \multirow{2}{*}{$\begin{array}{c}\text { Part of the } \\
\text { top-down overall } \\
\text { "battery } \\
\text { manufacturing" }\end{array}$} & \multicolumn{4}{|c|}{$\begin{array}{l}\text { Additional process-wise information } \\
\text { for direct energy requirements? }\end{array}$} \\
\hline & & $\begin{array}{c}\text { Estimate } \\
\text { in } \\
\text { literature }\end{array}$ & $\begin{array}{l}\text { Use model or } \\
\text { thermodynami } \\
\text { c calculations }\end{array}$ & $\begin{array}{c}\text { Use } \\
\text { of } \\
\text { Prox } \\
y\end{array}$ & $\mathrm{No}^{*}$ \\
\hline $\begin{array}{l}\text { Production of positive electrode pastes for lithium ion } \\
\text { battery (NCM or LFP) }\end{array}$ & yes & & & & $\mathrm{X}$ \\
\hline $\begin{array}{l}\text { Production of negative electrode paste of lithium ion } \\
\text { battery (NCM or LFP) }\end{array}$ & yes & & $\mathrm{X}$ & & \\
\hline Production of electrolyte for Li-ion battery & yes & & & & $\mathrm{X}$ \\
\hline Production of $\mathrm{LiFePO} 4$ & yes & & $\mathrm{X}$ & & \\
\hline Production of LiNi0.4Co0.2Mn0.4O2 & yes & & $\mathrm{X}$ & & \\
\hline $\begin{array}{l}\text { Production of electrode substrates for lithium ion } \\
\text { battery }\end{array}$ & yes & & & $\mathrm{X}$ & \\
\hline Production of transition metal hydroxides & yes & & & & $\mathrm{X}$ \\
\hline Production of battery management system & yes & & & $\mathrm{X}$ & \\
\hline Production of Negative Electrode Paste for NiMH & yes & & $\mathrm{X}$ & & \\
\hline Production of Positive Electrode Paste for NiMH & yes & & & & $\mathrm{X}$ \\
\hline Production of electrolyte for NiMH battery & yes & & & & $\mathrm{X}$ \\
\hline Production of NiMH electrode substrate & yes & & & $\mathrm{X}$ & \\
\hline Production of cell containers & yes & & & $\mathrm{X}$ & \\
\hline Production of separator & yes & & & $\mathrm{X}$ & \\
\hline Production of module and battery packing & yes & & & $\mathrm{X}$ & \\
\hline Production of NiSO4 and $\mathrm{CoSO} 4$ & NO (virgin) & & $X$ & $X$ & \\
\hline Production of MnSO4 & NO (virgin) & & & & \\
\hline
\end{tabular}

"Full allocation of process energy requirement to the overall "battery manufacturing"; no further disaggregation.

\section{Complete Numerical Results}

Total life cycle impacts are presented quantitatively in the main paper. The impacts are also broken down between use-phase and production (Main Paper, Figure 1), and then further split in a componentwise manner (Main Paper, Figure 2), but only graphically. We here present the data underlying these figures (Tables S27, S28, S29). The following impacts are for $50 \mathrm{MJ}$ of energy delivered to the powertrain. 
Table S27: NiMH life cycle impact for storing and delivering $50 \mathrm{MJ}$ of electrical energy to a power-train, broken down amongst key components

\begin{tabular}{|c|c|c|c|c|c|c|c|c|c|c|c|}
\hline & & Battery Use & $\begin{array}{c}\text { Battery \& } \\
\text { e Components } \\
\text { Manufacture }\end{array}$ & $\begin{array}{c}\text { Positive } \\
\text { Electrode } \\
\text { Paste }\end{array}$ & $\begin{array}{c}\text { Negative } \\
\text { Electrode } \\
\text { Paste }\end{array}$ & Electrolyte & Separator & $\begin{array}{c}\text { Cell } \\
\text { Container }\end{array}$ & $\begin{array}{c}\text { Module \& } \\
\text { Battery } \\
\text { Casing }\end{array}$ & $\begin{array}{l}\text { Electrode } \\
\text { substrates }\end{array}$ & $\begin{array}{l}\text { Electricity } \\
\text { Consumed } \\
\text { by Battery }\end{array}$ \\
\hline $\mathrm{GWP}_{100}$ & $k g C O 2-e q$ & $2.5 \mathrm{E}-5$ & 7.4E-1 & $2.6 \mathrm{E}-1$ & $4.8 \mathrm{E}-1$ & $5.2 \mathrm{E}-3$ & $1.4 \mathrm{E}-2$ & $4.3 \mathrm{E}-2$ & 7.4E-2 & 4.4E-1 & $1.5 \mathrm{E}+0$ \\
\hline FDP & kg oil-eq & $8.5 \mathrm{E}-6$ & $2.4 \mathrm{E}-1$ & $3.4 \mathrm{E}-2$ & $1.1 \mathrm{E}-1$ & $1.7 \mathrm{E}-3$ & $8.8 \mathrm{E}-3$ & $1.3 \mathrm{E}-2$ & $3.9 \mathrm{E}-2$ & $1.2 \mathrm{E}-1$ & $4.3 \mathrm{E}-1$ \\
\hline FETP $_{\text {inf }}$ & $k g$ 1,4-DCB-eq & 7.4E-8 & $7.1 \mathrm{E}-3$ & $1.5 \mathrm{E}-2$ & $2.1 \mathrm{E}-2$ & $5.0 \mathrm{E}-5$ & 7.7E-5 & $3.5 \mathrm{E}-3$ & $5.4 \mathrm{E}-4$ & $5.8 \mathrm{E}-2$ & $2.1 \mathrm{E}-2$ \\
\hline FEP & $k g P-e q$ & 4.3E-9 & $4.9 \mathrm{E}-4$ & $3.9 \mathrm{E}-4$ & $6.0 \mathrm{E}-4$ & $3.2 \mathrm{E}-6$ & 4.1E-6 & $2.0 \mathrm{E}-5$ & $3.2 \mathrm{E}-5$ & $1.5 \mathrm{E}-3$ & $1.5 \mathrm{E}-3$ \\
\hline $\mathrm{HTP}_{\text {inf }}$ & $k g$ 1,4-DCB-eq & $3.4 \mathrm{E}-6$ & 3.3E-1 & 7.3E-1 & $9.4 \mathrm{E}-1$ & $2.5 \mathrm{E}-3$ & $3.6 \mathrm{E}-3$ & $3.8 \mathrm{E}-2$ & $3.0 \mathrm{E}-2$ & $2.6 \mathrm{E}+0$ & $9.6 \mathrm{E}-1$ \\
\hline METP $_{\text {inf }}$ & $k g$ 1,4-DCB-eq & $1.4 \mathrm{E}-7$ & 7.1E-3 & $1.5 \mathrm{E}-2$ & $2.3 \mathrm{E}-2$ & $5.1 \mathrm{E}-5$ & $6.9 \mathrm{E}-5$ & $3.7 \mathrm{E}-3$ & $5.8 \mathrm{E}-4$ & $6.3 \mathrm{E}-2$ & $2.0 \mathrm{E}-2$ \\
\hline MEP & $k g N-e q$ & $4.7 \mathrm{E}-8$ & $5.9 \mathrm{E}-4$ & $2.5 \mathrm{E}-4$ & $4.6 \mathrm{E}-4$ & $6.1 \mathrm{E}-6$ & $6.8 \mathrm{E}-6$ & $3.3 \mathrm{E}-5$ & $4.3 \mathrm{E}-5$ & $9.5 \mathrm{E}-4$ & $1.7 \mathrm{E}-3$ \\
\hline MDP & $\mathrm{kg} \mathrm{Fe}-e q$ & $3.6 \mathrm{E}-7$ & $8.2 \mathrm{E}-3$ & $1.6 \mathrm{E}-1$ & $2.2 \mathrm{E}-1$ & $2.9 \mathrm{E}-4$ & 4.9E-4 & 7.2E-2 & $4.5 \mathrm{E}-3$ & $6.3 \mathrm{E}-1$ & $1.6 \mathrm{E}-2$ \\
\hline $\mathrm{ODP}_{\text {inf }}$ & $k g C F C-11-e q$ & $2.8 \mathrm{E}-12$ & $5.8 \mathrm{E}-8$ & 4.3E-6 & $5.9 \mathrm{E}-6$ & $4.4 \mathrm{E}-10$ & $3.5 \mathrm{E}-9$ & $2.6 \mathrm{E}-9$ & $1.8 \mathrm{E}-8$ & $3.4 \mathrm{E}-8$ & 7.2E-8 \\
\hline PMFP & kg PM10-eq & $1.6 \mathrm{E}-7$ & 7.4E-4 & $3.2 \mathrm{E}-3$ & $4.6 \mathrm{E}-3$ & $6.4 \mathrm{E}-6$ & $1.6 \mathrm{E}-5$ & $2.1 \mathrm{E}-4$ & $8.6 \mathrm{E}-5$ & $1.3 \mathrm{E}-2$ & $1.9 \mathrm{E}-3$ \\
\hline POFP & kg NMVOC & 3.9E-7 & $1.3 \mathrm{E}-3$ & $1.9 \mathrm{E}-3$ & $2.9 \mathrm{E}-3$ & $1.3 \mathrm{E}-5$ & 4.9E-5 & $1.5 \mathrm{E}-4$ & $2.0 \mathrm{E}-4$ & $7.4 \mathrm{E}-3$ & $3.1 \mathrm{E}-3$ \\
\hline TAP $_{100}$ & kg SO2-eq & $5.1 \mathrm{E}-7$ & $2.3 \mathrm{E}-3$ & $1.4 \mathrm{E}-2$ & $1.9 \mathrm{E}-2$ & $1.9 \mathrm{E}-5$ & 4.7E-5 & $2.2 \mathrm{E}-4$ & $2.5 \mathrm{E}-4$ & $5.6 \mathrm{E}-2$ & $6.1 \mathrm{E}-3$ \\
\hline TETP $_{\text {inf }}$ & $k g$ 1,4-DCB-eq & 2.3E-9 & $5.4 \mathrm{E}-5$ & $2.6 \mathrm{E}-4$ & $2.2 \mathrm{E}-4$ & 4.8E-7 & $6.7 \mathrm{E}-7$ & $1.0 \mathrm{E}-5$ & $6.0 \mathrm{E}-6$ & $5.1 \mathrm{E}-4$ & $1.1 \mathrm{E}-4$ \\
\hline
\end{tabular}

Impact Categories: global warming (GWP), fossil depletion (FDP), freshwater ecotoxicity (FETP), freshwater eutrophication (FEP), human toxicity (HTP), marine ecotoxicity (METP), marine eutrophication (MEP), metal depletion (MDP), ozone depletion (ODP), particulate matter formation (PMFP), terrestrial acidification

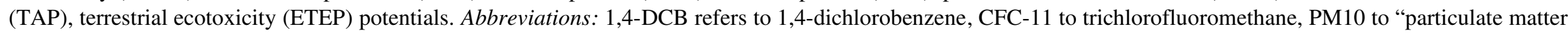
less than $10 \mu \mathrm{m}$ in diameter", NMVOC to "non methane volatile organic carbon". The suffixes "inf" and "100" refer to infinity and 100 years, respectively. 
Table S28: NCM Li-ion life cycle impact for storing and delivering $50 \mathrm{MJ}$ of electrical energy to a power-train, broken down amongst key components

\begin{tabular}{|c|c|c|c|c|c|c|c|c|c|c|c|c|c|}
\hline & & $\begin{array}{c}\text { Battery } \\
\text { Use }\end{array}$ & $\begin{array}{c}\text { Battery \& } \\
\text { Components } \\
\text { Manufacture }\end{array}$ & $\begin{array}{c}\text { Positive } \\
\text { Electrode } \\
\text { Paste } \\
\end{array}$ & $\begin{array}{c}\text { Negative } \\
\text { Electrode } \\
\text { Paste }\end{array}$ & Electrolyte & Separator & $\begin{array}{c}\text { Cell } \\
\text { Container }\end{array}$ & $\begin{array}{c}\text { Module \& } \\
\text { Battery } \\
\text { Casing } \\
\end{array}$ & BMS & $\begin{array}{c}\text { Substrate of } \\
\text { Negative } \\
\text { Electrode } \\
\end{array}$ & $\begin{array}{l}\text { Substrate } \\
\text { of Positive } \\
\text { Electrode }\end{array}$ & $\begin{array}{l}\text { Electricity } \\
\text { Consumed } \\
\text { by Battery }\end{array}$ \\
\hline $\mathrm{GWP}_{100}$ & $\mathrm{~kg} \mathrm{CO} 2-e q$ & $1.2 \mathrm{E}-5$ & $3.1 \mathrm{E}-1$ & $3.9 \mathrm{E}-1$ & 8.7E-2 & $1.2 \mathrm{E}-2$ & $6.0 \mathrm{E}-3$ & $9.6 \mathrm{E}-2$ & $3.6 \mathrm{E}-2$ & $1.6 \mathrm{E}-1$ & $1.5 \mathrm{E}-2$ & $1.7 \mathrm{E}-2$ & $7.4 \mathrm{E}-1$ \\
\hline FDP & kg oil-eq & $4.2 \mathrm{E}-6$ & $1.0 \mathrm{E}-1$ & $2.9 \mathrm{E}-2$ & $4.4 \mathrm{E}-3$ & $8.4 \mathrm{E}-3$ & $3.8 \mathrm{E}-3$ & $2.5 \mathrm{E}-2$ & $1.9 \mathrm{E}-2$ & $4.2 \mathrm{E}-2$ & $4.6 \mathrm{E}-3$ & $4.4 \mathrm{E}-3$ & $2.1 \mathrm{E}-1$ \\
\hline FETP $_{\text {inf }}$ & $k g$ 1,4-DCB-eq & $3.7 \mathrm{E}-8$ & $2.9 \mathrm{E}-3$ & $4.5 \mathrm{E}-3$ & $6.4 \mathrm{E}-5$ & $6.3 \mathrm{E}-5$ & $3.3 \mathrm{E}-5$ & $1.0 \mathrm{E}-3$ & $2.7 \mathrm{E}-4$ & $1.6 \mathrm{E}-2$ & $1.6 \mathrm{E}-2$ & $1.9 \mathrm{E}-4$ & $1.0 \mathrm{E}-2$ \\
\hline FEP & $k g P-e q$ & $2.1 \mathrm{E}-9$ & $2.1 \mathrm{E}-4$ & $1.4 \mathrm{E}-4$ & $3.8 \mathrm{E}-6$ & $3.2 \mathrm{E}-6$ & $1.8 \mathrm{E}-6$ & $4.4 \mathrm{E}-5$ & $1.6 \mathrm{E}-5$ & $8.1 \mathrm{E}-4$ & $7.7 \mathrm{E}-4$ & $8.0 \mathrm{E}-6$ & 7.3E-4 \\
\hline $\mathrm{HTP}_{\text {inf }}$ & kg 1,4-DCB-eq & $1.7 \mathrm{E}-6$ & $1.4 \mathrm{E}-1$ & $2.4 \mathrm{E}-1$ & $8.6 \mathrm{E}-3$ & $3.1 \mathrm{E}-3$ & $1.6 \mathrm{E}-3$ & 4.3E-2 & $1.5 \mathrm{E}-2$ & $1.4 \mathrm{E}+0$ & $1.8 \mathrm{E}+0$ & $7.8 \mathrm{E}-3$ & $4.8 \mathrm{E}-1$ \\
\hline METP $_{\text {inf }}$ & kg 1,4-DCB-eq & $6.9 \mathrm{E}-8$ & $3.0 \mathrm{E}-3$ & $4.6 \mathrm{E}-3$ & $7.0 \mathrm{E}-5$ & $6.1 \mathrm{E}-5$ & $2.9 \mathrm{E}-5$ & $1.1 \mathrm{E}-3$ & $2.8 \mathrm{E}-4$ & $1.6 \mathrm{E}-2$ & $2.0 \mathrm{E}-2$ & $2.0 \mathrm{E}-4$ & $1.0 \mathrm{E}-2$ \\
\hline MEP & $k g N-e q$ & $2.3 \mathrm{E}-8$ & $2.5 \mathrm{E}-4$ & $6.2 \mathrm{E}-4$ & $1.9 \mathrm{E}-4$ & $5.4 \mathrm{E}-6$ & $2.9 \mathrm{E}-6$ & $5.6 \mathrm{E}-5$ & $2.1 \mathrm{E}-5$ & $3.2 \mathrm{E}-4$ & $2.1 \mathrm{E}-4$ & $1.0 \mathrm{E}-5$ & $8.4 \mathrm{E}-4$ \\
\hline MDP & kg Fe-eq & $1.8 \mathrm{E}-7$ & $3.0 \mathrm{E}-3$ & $3.8 \mathrm{E}-1$ & 4.7E-4 & $6.4 \mathrm{E}-4$ & $2.1 \mathrm{E}-4$ & $4.8 \mathrm{E}-3$ & $2.2 \mathrm{E}-3$ & $2.0 \mathrm{E}-1$ & $2.5 \mathrm{E}-1$ & $8.7 \mathrm{E}-4$ & $8.0 \mathrm{E}-3$ \\
\hline $\mathrm{ODP}_{\mathrm{inf}}$ & kg CFC-11-eq & $1.4 \mathrm{E}-12$ & $2.4 \mathrm{E}-8$ & $9.0 \mathrm{E}-6$ & $2.3 \mathrm{E}-6$ & $1.1 \mathrm{E}-9$ & $1.5 \mathrm{E}-9$ & $6.5 \mathrm{E}-9$ & $8.7 \mathrm{E}-9$ & $1.7 \mathrm{E}-8$ & $1.2 \mathrm{E}-9$ & $1.2 \mathrm{E}-9$ & $3.6 \mathrm{E}-8$ \\
\hline PMFP & kg PM10-eq & $7.8 \mathrm{E}-8$ & $3.1 \mathrm{E}-4$ & $1.0 \mathrm{E}-3$ & $1.4 \mathrm{E}-5$ & $1.5 \mathrm{E}-5$ & $6.8 \mathrm{E}-6$ & $1.9 \mathrm{E}-4$ & $4.3 \mathrm{E}-5$ & $3.8 \mathrm{E}-4$ & $6.6 \mathrm{E}-4$ & $3.4 \mathrm{E}-5$ & $9.7 \mathrm{E}-4$ \\
\hline POFP & kg NMVOC & $1.9 \mathrm{E}-7$ & $5.5 \mathrm{E}-4$ & $8.0 \mathrm{E}-4$ & $2.6 \mathrm{E}-5$ & $3.9 \mathrm{E}-5$ & $2.1 \mathrm{E}-5$ & $2.4 \mathrm{E}-4$ & $9.9 \mathrm{E}-5$ & $6.8 \mathrm{E}-4$ & $4.2 \mathrm{E}-4$ & $4.4 \mathrm{E}-5$ & $1.5 \mathrm{E}-3$ \\
\hline $\mathrm{TAP}_{100}$ & $k g S O 2-e q$ & $2.5 \mathrm{E}-7$ & $9.7 \mathrm{E}-4$ & $4.3 \mathrm{E}-3$ & 4.9E-5 & $4.4 \mathrm{E}-5$ & $2.0 \mathrm{E}-5$ & $3.9 \mathrm{E}-4$ & $1.2 \mathrm{E}-4$ & $1.1 \mathrm{E}-3$ & $2.1 \mathrm{E}-3$ & 7.1E-5 & $3.1 \mathrm{E}-3$ \\
\hline TETP $_{\text {inf }}$ & kg 1,4-DCB-eq & $1.1 \mathrm{E}-9$ & $2.3 \mathrm{E}-5$ & $7.6 \mathrm{E}-5$ & $1.1 \mathrm{E}-6$ & $1.0 \mathrm{E}-6$ & $2.9 \mathrm{E}-7$ & $9.2 \mathrm{E}-6$ & $3.0 \mathrm{E}-6$ & $3.7 \mathrm{E}-5$ & $9.9 \mathrm{E}-5$ & $1.7 \mathrm{E}-6$ & $5.6 \mathrm{E}-5$ \\
\hline
\end{tabular}

Impact Categories: global warming (GWP), fossil depletion (FDP), freshwater ecotoxicity (FETP), freshwater eutrophication (FEP), human toxicity (HTP), marine ecotoxicity (METP), marine eutrophication (MEP), metal depletion (MDP), ozone depletion (ODP), particulate matter formation (PMFP), terrestrial acidification

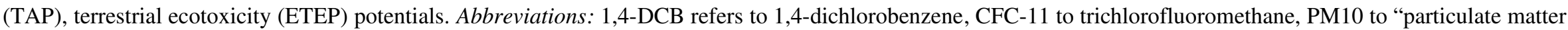
less than $10 \mu \mathrm{m}$ in diameter", NMVOC to "non methane volatile organic carbon". The suffixes "inf" and " 100 " refer to infinity and 100 years, respectively. 
Table S29: LFP Li-ion life cycle impact for storing and delivering $50 \mathrm{MJ}$ of electrical energy to a power-train, broken down amongst key components

\begin{tabular}{|c|c|c|c|c|c|c|c|c|c|c|c|c|c|}
\hline & & $\begin{array}{c}\text { Battery } \\
\text { Use }\end{array}$ & $\begin{array}{c}\text { Battery \& } \\
\text { Components } \\
\text { Manufacture }\end{array}$ & $\begin{array}{c}\text { Positive } \\
\text { Electrode } \\
\text { Paste } \\
\end{array}$ & $\begin{array}{c}\text { Negative } \\
\text { Electrode } \\
\text { Paste } \\
\end{array}$ & Electrolyte & Separator & $\begin{array}{c}\text { Cell } \\
\text { Container }\end{array}$ & $\begin{array}{c}\text { Module \& } \\
\text { Battery } \\
\text { Casing } \\
\end{array}$ & BMS & $\begin{array}{c}\text { Substrate of } \\
\text { Negative } \\
\text { Electrode }\end{array}$ & $\begin{array}{c}\text { Substrate } \\
\text { of Positive } \\
\text { Electrode }\end{array}$ & $\begin{array}{l}\text { Electricity } \\
\text { Consumed } \\
\text { by Battery }\end{array}$ \\
\hline $\mathrm{GWP}_{100}$ & $k g C O 2-e q$ & $7.8 \mathrm{E}-6$ & $2.0 \mathrm{E}-1$ & $2.5 \mathrm{E}-1$ & $4.7 \mathrm{E}-2$ & $7.8 \mathrm{E}-3$ & $3.8 \mathrm{E}-3$ & $6.1 \mathrm{E}-2$ & $2.3 \mathrm{E}-2$ & $1.0 \mathrm{E}-1$ & $9.7 \mathrm{E}-3$ & $1.1 \mathrm{E}-2$ & $7.4 \mathrm{E}-1$ \\
\hline FDP & kg oil-eq & $2.7 \mathrm{E}-6$ & $6.4 \mathrm{E}-2$ & $1.7 \mathrm{E}-2$ & $2.4 \mathrm{E}-3$ & $5.3 \mathrm{E}-3$ & $2.4 \mathrm{E}-3$ & $1.6 \mathrm{E}-2$ & $1.2 \mathrm{E}-2$ & 2.7E-2 & $2.9 \mathrm{E}-3$ & $2.8 \mathrm{E}-3$ & $2.1 \mathrm{E}-1$ \\
\hline FETP $_{\text {inf }}$ & kg 1,4-DCB-eq & $2.3 \mathrm{E}-8$ & $1.9 \mathrm{E}-3$ & $4.8 \mathrm{E}-4$ & $3.5 \mathrm{E}-5$ & $4.0 \mathrm{E}-5$ & $2.1 \mathrm{E}-5$ & $6.6 \mathrm{E}-4$ & $1.7 \mathrm{E}-4$ & $1.0 \mathrm{E}-2$ & $9.9 \mathrm{E}-3$ & $1.2 \mathrm{E}-4$ & $1.0 \mathrm{E}-2$ \\
\hline FEP & $k g P-e q$ & $1.4 \mathrm{E}-9$ & $1.3 \mathrm{E}-4$ & $1.2 \mathrm{E}-4$ & $2.0 \mathrm{E}-6$ & $2.0 \mathrm{E}-6$ & $1.1 \mathrm{E}-6$ & $2.8 \mathrm{E}-5$ & $1.0 \mathrm{E}-5$ & $5.1 \mathrm{E}-4$ & 4.9E-4 & $5.0 \mathrm{E}-6$ & 7.3E-4 \\
\hline $\mathrm{HTP}_{\mathrm{inf}}$ & $k g$ 1,4-DCB-eq & $1.1 \mathrm{E}-6$ & $8.7 \mathrm{E}-2$ & $3.3 \mathrm{E}-2$ & 4.7E-3 & $2.0 \mathrm{E}-3$ & $9.9 \mathrm{E}-4$ & $2.7 \mathrm{E}-2$ & $9.3 \mathrm{E}-3$ & 8.7E-1 & $1.1 \mathrm{E}+0$ & $4.9 \mathrm{E}-3$ & $4.8 \mathrm{E}-1$ \\
\hline METP $_{\text {inf }}$ & $k g$ 1,4-DCB-eq & $4.4 \mathrm{E}-8$ & $1.9 \mathrm{E}-3$ & $5.0 \mathrm{E}-4$ & $3.8 \mathrm{E}-5$ & $3.9 \mathrm{E}-5$ & $1.9 \mathrm{E}-5$ & $6.9 \mathrm{E}-4$ & $1.8 \mathrm{E}-4$ & $1.0 \mathrm{E}-2$ & $1.3 \mathrm{E}-2$ & $1.2 \mathrm{E}-4$ & $1.0 \mathrm{E}-2$ \\
\hline MEP & $k g N-e q$ & $1.5 \mathrm{E}-8$ & $1.6 \mathrm{E}-4$ & $3.7 \mathrm{E}-4$ & $1.0 \mathrm{E}-4$ & $3.5 \mathrm{E}-6$ & $1.9 \mathrm{E}-6$ & $3.6 \mathrm{E}-5$ & $1.3 \mathrm{E}-5$ & $2.0 \mathrm{E}-4$ & $1.3 \mathrm{E}-4$ & $6.5 \mathrm{E}-6$ & $8.4 \mathrm{E}-4$ \\
\hline MDP & $k g \mathrm{Fe}-e q$ & $1.1 \mathrm{E}-7$ & $1.9 \mathrm{E}-3$ & $3.1 \mathrm{E}-3$ & $2.5 \mathrm{E}-4$ & 4.1E-4 & $1.3 \mathrm{E}-4$ & $3.0 \mathrm{E}-3$ & $1.4 \mathrm{E}-3$ & $1.2 \mathrm{E}-1$ & $1.6 \mathrm{E}-1$ & $5.5 \mathrm{E}-4$ & $8.0 \mathrm{E}-3$ \\
\hline $\mathrm{ODP}_{\mathrm{inf}}$ & $k g C F C-11-e q$ & $8.9 \mathrm{E}-13$ & $1.6 \mathrm{E}-8$ & $6.1 \mathrm{E}-6$ & $1.2 \mathrm{E}-6$ & $6.7 \mathrm{E}-10$ & $9.4 \mathrm{E}-10$ & $4.1 \mathrm{E}-9$ & $5.6 \mathrm{E}-9$ & $1.1 \mathrm{E}-8$ & $7.8 \mathrm{E}-10$ & $7.4 \mathrm{E}-10$ & $3.6 \mathrm{E}-8$ \\
\hline PMFP & kg PM10-eq & $4.9 \mathrm{E}-8$ & $2.0 \mathrm{E}-4$ & $9.9 \mathrm{E}-5$ & $7.6 \mathrm{E}-6$ & $9.3 \mathrm{E}-6$ & $4.3 \mathrm{E}-6$ & $1.2 \mathrm{E}-4$ & $2.7 \mathrm{E}-5$ & $2.4 \mathrm{E}-4$ & $4.2 \mathrm{E}-4$ & $2.1 \mathrm{E}-5$ & $9.7 \mathrm{E}-4$ \\
\hline POFP & kg NMVOC & $1.2 \mathrm{E}-7$ & $3.5 \mathrm{E}-4$ & $1.4 \mathrm{E}-4$ & $1.4 \mathrm{E}-5$ & $2.5 \mathrm{E}-5$ & $1.3 \mathrm{E}-5$ & $1.5 \mathrm{E}-4$ & $6.3 \mathrm{E}-5$ & $4.4 \mathrm{E}-4$ & $2.7 \mathrm{E}-4$ & $2.8 \mathrm{E}-5$ & $1.5 \mathrm{E}-3$ \\
\hline $\mathrm{TAP}_{100}$ & kg SO2-eq & $1.6 \mathrm{E}-7$ & $6.2 \mathrm{E}-4$ & $3.4 \mathrm{E}-4$ & $2.6 \mathrm{E}-5$ & $2.8 \mathrm{E}-5$ & $1.3 \mathrm{E}-5$ & $2.5 \mathrm{E}-4$ & $7.8 \mathrm{E}-5$ & $7.0 \mathrm{E}-4$ & $1.3 \mathrm{E}-3$ & $4.5 \mathrm{E}-5$ & $3.1 \mathrm{E}-3$ \\
\hline TETP $_{\text {inf }}$ & kg 1,4-DCB-eq & $7.2 \mathrm{E}-10$ & $1.4 \mathrm{E}-5$ & 7.7E-6 & $6.2 \mathrm{E}-7$ & $6.6 \mathrm{E}-7$ & $1.8 \mathrm{E}-7$ & $5.8 \mathrm{E}-6$ & $1.9 \mathrm{E}-6$ & $2.4 \mathrm{E}-5$ & $6.3 \mathrm{E}-5$ & $1.1 \mathrm{E}-6$ & $5.6 \mathrm{E}-5$ \\
\hline
\end{tabular}

Impact Categories: global warming (GWP), fossil depletion (FDP), freshwater ecotoxicity (FETP), freshwater eutrophication (FEP), human toxicity (HTP), marine ecotoxicity (METP), marine eutrophication (MEP), metal depletion (MDP), ozone depletion (ODP), particulate matter formation (PMFP), terrestrial acidification

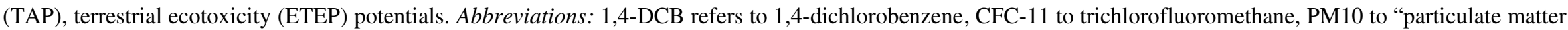
less than $10 \mu \mathrm{m}$ in diameter", NMVOC to "non methane volatile organic carbon". The suffixes "inf" and " 100 " refer to infinity and 100 years, respectively. 


\section{Structural Path Analysis}

The main paper cites particularly interesting results from structural path analysis (SPA). We here present a broader selection of these, covering the most important paths for a few impact categories. Thus, some of the most important paths causing GWP for NiMH, NCM and LFP batteries are presented in SPA S1, 4, and 7, respectively. Important path for human toxicity in the life cycle of $\mathrm{NiMH}$ and NCM were respectively reported in SPA S3 and 5. The freshwater ecotoxicity of NiMH (SPA S2), the marine ecotoxicity of NCM (SPA S6) and the ozone depletion related to LFP life cycle (SPA S8) were also reported. The impact of each path are presented in absolute terms, and relative to the total life cycle impact. As these are "raw" results, we present them to the highest level of resolution possible, without regards to uncertainty or significant figures. 
SPA S1: Most important paths for global warming potential impacts of NIMH life cycle

\section{ABSOLUTE (kg CO2-eq); RELATIVE (\%) : SEQUENCE>}

0.1927189315; 5.465956725: Battery Use_NiMH $>$ Electricity Consumed by Battery> electricity, medium voltage, production UCTE, at grid $>$ electricity, high voltage, production UCTE, at grid $>$ electricity, production mix UCTE $>$ electricity, production mix DE $>$ electricity, lignite, at power plant $>$ lignite, burned in power plant

0.1692806747, 4.801193299: Battery Use_NiMH $>$ Battery Assembly_NiMH $>$ heat, natural gas, at industrial furnace low-NOx $>100 \mathrm{~kW}>$ natural gas, burned in industrial furnace low-NOx $>100 \mathrm{~kW}$

0.1361297714; 3.860956647: Battery Use_NiMH> Electricity Consumed by Battery> electricity, medium voltage, production UCTE, at grid > electricity, high voltage, production UCTE, at grid> electricity, production mix UCTE $>$ electricity, production mix DE $>$ electricity, hard coal, at power plant $>$ hard coal, burned in power plant

0.1152944725; 3.270019153: Battery Use_NiMH> Battery Assembly_NiMH> Negative Electrode_AB5_MH_NiMH>tetrafluoroethylene, at plant

0.08783795666; 2.491288563: Battery Use_NiMH $>$ Electricity Consumed by Battery $>$ electricity, medium voltage, production UCTE, at grid $>$ electricity, high voltage, production UCTE, at grid $>$ electricity, production mix UCTE $>$ electricity, production mix PL > electricity, hard coal, at power plant $>$ hard coal, burned in power plant

0.08417692071; 2.387453077: Battery Use_NiMH> Battery Assembly_NiMH $>$ Positive Electrode Material_ Ni_ NiMH> tetrafluoroethylene, at plant

0.07608270577; 2.157882332: Battery Use_NiMH> Electricity Consumed by Battery > electricity, medium voltage, production UCTE, at grid > electricity, high voltage, production UCTE, at grid> electricity, production mix UCTE $>$ electricity, production mix IT > electricity, natural gas, at power plant $>$ natural gas, burned in power plant

0.07583573873; 2.150877773: Battery Use_NiMH $>$ Battery Assembly_NiMH $>$ Negative Electrode_AB5_MH_NiMH $>$ tetrafluoroethylene, at plant $>$ chlorodifluoromethane, at plant

0.07044034951;.997851997: Battery Use_NiMH> Electricity Consumed by Battery> electricity, medium voltage, production UCTE, at grid > electricity, high voltage, production UCTE, at grid> electricity, production mix UCTE $>$ electricity, production mix ES> electricity, hard coal, at power plant $>$ hard coal, burned in power plant

0.0688529278; 1.952829029: Battery Use_NiMH $>$ Battery Assembly_NiMH $>$ Substrate_ Nickel Foam_ NiMH $>$ nickel, 99.5\%, at plant $>$ heavy fuel oil, burned in industrial furnace 1MW, non-modulating

0.06715870651; 1.904776976: Battery Use_NiMH> Battery Assembly_NiMH>S Substrate_ Nickel Foam_NiMH> nickel, 99.5\%, at plant $>$ portland calcareous cement, at plant> clinker, at plant

0.06335045909; 1.79676623: Battery Use_ NiMH $>$ Battery Assembly_NiMH $>$ electricity, medium voltage, production UCTE, at grid $>$ electricity, high voltage, production UCTE, at grid $>$ electricity, production mix UCTE $>$ electricity, production mix DE $>$ electricity, lignite, at power plant $>$ lignite, burned in power plant

0.06194660234; 1.75694959: Battery Use_NiMH > Electricity Consumed by Battery> electricity, medium voltage, production UCTE, at grid $>$ electricity, high voltage, production UCTE, at grid $>$ electricity, production mix UCTE > electricity, production mix PL $>$ electricity, lignite, at power plant> lignite, burned in power plant 
SPA S2: Most important paths for freshwater ecotoxicity potential impacts of NIMH life cycle

\section{ABSOLUTE (kg-DCB-eq); RELATIVE(\%): SEQUENCE:}

0.02775295402; 22.17769266 : Battery Use_NiMH $>$ Battery Assembly_NiMH $>$ Substrate_ Nickel Foam_NiMH $>$ nickel, 99.5\%, at plant $>$ disposal, sulfidic tailings, off-site

0.02743987885; 21.92751083: Battery Use_NiMH> Battery Assembly_ NiMH $>$ Substrate_ Nickel Foam_ NiMH> nickel, 99.5\%, at plant $>$ disposal, nickel smelter slag, 0\% water, to residual material landfill

0.009212175665; 7.361551515: Battery Use_NiMH> Battery Assembly_NiMH $>$ Negative Electrode_AB5_MH_NiMH> nickel, 99.5\%, at plant> disposal, sulfidic tailings, off-site

0.009108255072; 7.278507419: Battery Use_NiMH> Battery Assembly_NiMH $>$ Negative Electrode_AB5_MH_NiMH> nickel, 99.5\%, at plant> disposal, nickel smelter slag, 0\% water, to residual material landfill

0.006974318485; 5.573255079: Battery Use_NiMH $>$ Battery Assembly_NiMH $>$ Positive Electrode Material_ Ni_NiMH $>$ Ni(OH) $2>$ NiSO4> disposal, sulfidic tailings, off-site

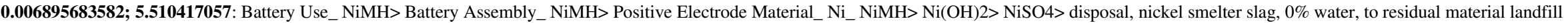

0.006039023145; 4.825850223: Battery Use_NiMH> Electricity Consumed by Battery > electricity, medium voltage, production UCTE, at grid $>$ electricity, high voltage, production UCTE, at grid $>$ electricity, production mix UCTE $>$ electricity, production mix DE $>$ electricity, lignite, at power plant $>$ lignite, burned in power plant $>$ lignite, at mine $>$ disposal, spoil from lignite mining, in surface landfill

0.002996682198; 2.394681905: Battery Use_NiMH> Battery Assembly_NiMH>Cell Container_Stainless_ NiMH> steel, electric, chromium steel 18/8, at plant $>$ ferronickel, 25\% Ni, at plant> disposal, nickel smelter slag, $0 \%$ water, to residual material landfill

0.002131734694; 1.703492784: Battery Use_NiMH> Electricity Consumed by Battery> electricity, medium voltage, production UCTE, at grid $>$ electricity, high voltage, production UCTE, at grid> electricity, production mix UCTE > electricity, production mix GR> electricity, lignite, at power plant $>$ lignite, burned in power plant> lignite, at mine> disposal, spoil from lignite mining, in surface landfil

0.002095323202; 1.674395957: Battery Use_NiMH> Electricity Consumed by Battery > electricity, medium voltage, production UCTE, at grid $>$ electricity, high voltage, production UCTE, at grid $>$ electricity, production mix UCTE > electricity, production mix PL $>$ electricity, lignite, at power plant $>$ lignite, burned in power plant> lignite, at mine> disposal, spoil from lignite mining, in surface landfill

0.001985144302; 1.586350779: Battery Use_NiMH> Battery Assembly_NiMH> electricity, medium voltage, production UCTE, at grid> electricity, high voltage, production UCTE, at grid> electricity, production mix UCTE > electricity, production mix DE > electricity, lignite, at power plant> lignite, burned in power plant $>$ lignite, at mine > disposal, spoil from lignite mining, in surface landfill

0.001277178099; 1.020607152: Battery Use_NiMH> Electricity Consumed by Battery > electricity, medium voltage, production UCTE, at grid $>$ electricity, high voltage, production UCTE, at grid $>$ electricity, production mix UCTE $>$ electricity, production mix CZ> electricity, lignite, at power plant> lignite, burned in power plant $>$ lignite, at mine $>$ disposal, spoil from lignite mining, in surface landfill 


\section{SPA S3: Most important paths for human toxicity potential impacts of NIMH life cycle}

\section{ABSOLUTE (kg-DCB-eq); RELATIVE (\%): SEQUENCE: >}

2.351571375; 42.08278383: Battery Use_NiMH $>$ Battery Assembly_NiMH $>$ Substrate_Nickel Foam_NiMH $>$ nickel, 99.5\%, at plant $>$ disposal, sulfidic tailings, off-site

0.7805687491; 13.96874714: Battery Use_NiMH $>$ Battery Assembly_NiMH $>$ Negative Electrode_AB5_MH_NiMH> nickel, 99.5\%, at plant> disposal, sulfidic tailings, off-site

0.5909499833; 10.57540531: Battery Use_NiMH $>$ Battery Assembly_NiMH $>$ Positive Electrode Material_ Ni_NiMH $>\mathrm{Ni}(\mathrm{OH}) 2>\mathrm{NiSO} 4>$ disposal, sulfidic tailings, off-site

0.2653040915; 4.747776254: Battery Use_NiMH $>$ Electricity Consumed by Battery $>$ electricity, medium voltage, production UCTE, at grid $>$ electricity, high voltage, production UCTE, at grid $>$ electricity, production mix UCTE $>$ electricity, production mix DE $>$ electricity, lignite, at power plant $>$ lignite, burned in power plant $>$ lignite, at mine $>$ disposal, spoil from lignite mining, in surface landfill

0.09365056613; 1.675933196: Battery Use_NiMH $>$ Electricity Consumed by Battery> electricity, medium voltage, production UCTE, at grid $>$ electricity, high voltage, production UCTE, at grid $>$ electricity, production mix UCTE > electricity, production mix GR $>$ electricity, lignite, at power plant $>$ lignite, burned in power plant $>$ lignite, at mine $>$ disposal, spoil from lignite mining, in surface landfill

0.09205095016; 1.647307106: Battery Use_NiMH $>$ Electricity Consumed by Battery > electricity, medium voltage, production UCTE, at grid $>$ electricity, high voltage, production UCTE, at grid $>$ electricity, production mix UCTE> electricity, production mix PL > electricity, lignite, at power plant> lignite, burned in power plant> lignite, at mine> disposal, spoil from lignite mining, in surface landfill

0.0875864839; 1.567412798: Battery Use_NiMH> Battery Assembly_NiMH $>$ Positive Electrode Material_ Ni_NiMH $>\mathrm{Ni}(\mathrm{OH}) 2>\mathrm{NiSO} 4$

0.08721061221; 1.560686348: Battery Use_NiMH $>$ Battery Assembly_NiMH $>$ electricity, medium voltage, production UCTE, at grid $>$ electricity, high voltage, production UCTE, at grid > electricity, production mix UCTE > electricity, production mix DE > electricity, lignite, at power plant> lignite, burned in power plant> lignite, at mine> disposal, spoil from lignite mining, in surface landfill

0.05610850745; 1.004095481: Battery Use_NiMH $>$ Electricity Consumed by Battery > electricity, medium voltage, production UCTE, at grid $>$ electricity, high voltage, production UCTE, at grid $>$ electricity, production mix UCTE $>$ electricity, production mix CZ> electricity, lignite, at power plant> lignite, burned in power plant> lignite, at mine $>$ disposal, spoil from lignite mining, in surface landfill

0.05020284007; 0.8984100117: Battery Use_NiMH $>$ Battery Assembly_NiMH $>$ Substrate_ Nickel Foam_NiMH $>$ nickel, 99.5\%, at plant

0.01666407768; 0.2982136908: Battery Use NiMH $>$ Battery Assembly_NiMH $>$ Negative Electrode_AB5_MH_NiMH $>$ nickel, 99.5\%, at plant 
SPA S4: Most important paths for global warming potential impacts of NCM life cycle

ABSOLUTE (kg CO2-eq); RELATIVE (\%): SEQUENCE: >

0.178606742; 9.549869574: Battery Use_NCM Li-Ion> Battery Assembly_ NCM Li-Ion> Positive Electrode Material_ NCM Li-Ion> tetrafluoroethylene, at plant

0.1174798231; 6.281492933: Battery Use_NCM Li-Ion> Battery Assembly_NCM Li-Ion> Positive Electrode Material_ NCM Li-Ion> tetrafluoroethylene, at plant> chlorodifluoromethane, at plant

0.09635946573; 5.152214969: Battery Use_NCM Li-Ion> Electricity Consumed by Battery > electricity, medium voltage, production UCTE, at grid $>$ electricity, high voltage, production UCTE, at grid> electricity, production mix UCTE $>$ electricity, production mix DE $>$ electricity, lignite, at power plant> lignite, burned in power plant

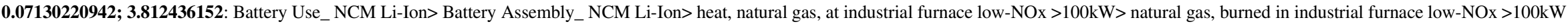

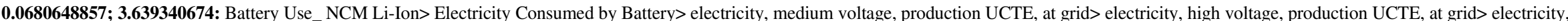
production mix UCTE $>$ electricity, production mix DE $>$ electricity, hard coal, at power plant $>$ hard coal, burned in power plant

0.04510096718; 2.411489898: Battery Use_NCM Li-Ion> Battery Assembly_NCM Li-Ion> Negative Electrode Material_Carbon_Li-Ion> tetrafluoroethylene, at plant

0.04391897833; 2.348290496: Battery Use NCM Li-Ion> Electricity Consumed by Battery> electricity, medium voltage, production UCTE, at grid $>$ electricity, high voltage, production UCTE, at grid> electricity, production mix UCTE $>$ electricity, production mix PL $>$ electricity, hard coal, at power plant $>$ hard coal, burned in power plant

0.03804135288; 2.034021529: Battery Use_NCM Li-Ion> Electricity Consumed by Battery > electricity, medium voltage, production UCTE, at grid> electricity, high voltage, production UCTE, at grid> electricity, production mix UCTE> electricity, production mix IT> electricity, natural gas, at power plant> natural gas, burned in power plant

0.03522017475; 1.883176813: Battery Use_NCM Li-Ion> Electricity Consumed by Battery> electricity, medium voltage, production UCTE, at grid $>$ electricity, high voltage, production UCTE, at grid> electricity, production mix UCTE $>$ electricity, production mix ES> electricity, hard coal, at power plant $>$ hard coal, burned in power plant

0.03097330117; 1.656102021: Battery Use_NCM Li-Ion> Electricity Consumed by Battery> electricity, medium voltage, production UCTE, at grid > electricity, high voltage, production UCTE, at grid> electricity, production mix UCTE $>$ electricity, production mix PL $>$ electricity, lignite, at power plant> lignite, burned in power plant

0.0296654739; 1.586174202: Battery Use_NCM Li-Ion> Battery Assembly_ NCM Li-Ion> Negative Electrode Material_Carbon_ Li-Ion> tetrafluoroethylene, at plant>chlorodifluoromethane, at plant

0.02668365842> 1.426740417: Battery Use_NCM Li-Ion> Battery Assembly_NCM Li-Ion> electricity, medium voltage, production UCTE, at grid> electricity, high voltage, production UCTE, at grid> electricity, production mix UCTE $>$ electricity, production mix DE $>$ electricity, lignite, at power plant $>$ lignite, burned in power plant

0.02612728078; 1.39699163: Battery Use_NCM Li-Ion> Battery Assembly_NCM Li-Ion>Cell Container_Al_Li-Ion> aluminum, production mix, at plant $>$ aluminum, primary, at plant> aluminum, primary, liquid, at plant

0.02536983969; 1.356492243: Battery Use_NCM Li-Ion> Electricity Consumed by Battery> electricity, medium voltage, production UCTE, at grid > electricity, high voltage, production UCTE, at grid> electricity, production mix UCTE $>$ electricity, production mix CZ> electricity, lignite, at power plant $>$ lignite, burned in power plant

0.02282757596; 1.220560717: Battery Use_NCM Li-Ion> Electricity Consumed by Battery> electricity, medium voltage, production UCTE, at grid> electricity, high voltage, production UCTE, at grid> electricity, production mix UCTE > electricity, production mix GR> electricity, lignite, at power plant $>$ lignite, burned in power plant

0.02123285324; 1.135292973: Battery Use_NCM Li-Ion> Electricity Consumed by Battery> electricity, medium voltage, production UCTE, at grid> electricity, high voltage, production UCTE, at grid> electricity, production mix UCTE $>$ electricity, production mix IT > electricity, hard coal, at power plant $>$ hard coal, burned in power plant 
SPA S5: Most important paths for human toxicity potential impacts of NCM life cycle

\section{ABSOLUTE (kg-DCB-eq); RELATIVE (\%): SEQUENCE}

1.072748568; 26.13494926: Battery Use_NCM Li-Ion> Battery Assembly_NCM Li-Ion> Substrate_Negative Electrode_Li-Ion> copper, primary, at refinery>copper concentrate, at beneficiation> disposal, sulfidic tailings, off-site

0.5076544453; 12.36778456: Battery Use_NCM Li-Ion> Battery Assembly_NCM Li-Ion> Substrate_ Negative Electrode_ Li-Ion> copper, primary, at refinery

0.329930081; 8.03795613: Battery Use_NCM Li-Ion> Battery Assembly_NCM Li-Ion> Battery Management System> integrated circuit, IC, logic type, at plant> gold, primary, at refinery> gold, at refinery> disposal, sulfidic tailings, off-site>

0.3233980639; 7.878819181: Battery Use_ NCM Li-Ion> Battery Assembly_NCM Li-Ion> Battery Management System> integrated circuit, IC, logic type, at plant> gold, primary, at refinery> gold, at refinery> disposal, sulfidic tailings, off-site>

0.1936968565; 4.718959939: Battery Use_NCM Li-Ion> Battery Assembly_NCM Li-Ion> Battery Management System> copper, primary, at refinery> copper concentrate, at beneficiation> disposal, sulfidic tailings, off-site

0.187533565; 4.568806104: Battery Use_NCM Li-Ion> Battery Assembly_NCM Li-Ion> Substrate_Negative Electrode_Li-Ion> copper, primary, at refinery> copper, SX-EW, at refinery> disposal, sulfidic tailings, off-site

0.1546332005; 3.767267533: Battery Use_NCM Li-Ion> Battery Assembly_NCM Li-Ion $>$ Positive Electrode Material_ NCM Li-Ion $>$ Li[ $[\mathrm{Ni0} .4 \mathrm{Co} 0.2 \mathrm{Mn} 0.4] \mathrm{O} 2>\mathrm{Ni0} .4 \mathrm{Co} 0.2 \mathrm{Mn} 0.4(\mathrm{OH}) 2>\mathrm{NiSO} 4>$ disposal, sulfidic tailings, off-site>

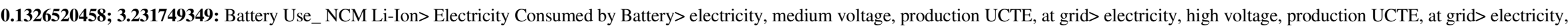
production mix UCTE > electricity, production mix DE $>$ electricity, lignite, at power plant> lignite, burned in power plant $>$ lignite, at mine $>$ disposal, spoil from lignite mining, in surface landfill

0.1034575354; 2.520495034: Battery Use_NCM Li-Ion> Battery Assembly_NCM Li-Ion> Battery Management System> integrated circuit, IC, logic type, at plant> gold, primary, at refinery> gold, from combined gold-silver production, at refinery> disposal, sulfidic tailings, off-site>

0.09166273738; 2.233143033: Battery Use_ NCM Li-Ion> Battery Assembly_ NCM Li-Ion> Battery Management System> copper, primary, at refinery

0.08779066324; 2.138809222: Battery Use_NCM Li-Ion> Battery Assembly_ NCM Li-Ion> Battery Management System> integrated circuit, IC, logic type, at plant> gold, primary, at refinery> gold, from combined gold-silver production, at refinery $>$ disposal, sulfidic tailings, off-site>

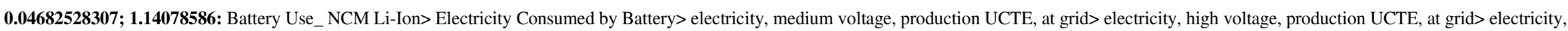
production mix UCTE > electricity, production mix GR > electricity, lignite, at power plant> lignite, burned in power plant $>$ lignite, at mine $>$ disposal, spoil from lignite mining, in surface landfill

0.04602547508; 1.121300454: Battery Use NCM Li-Ion> Electricity Consumed by Battery> electricity, medium voltage, production UCTE, at grid > electricity, high voltage, production UCTE, at grid> electricity, production mix UCTE $>$ electricity, production mix PL $>$ electricity, lignite, at power plant> lignite, burned in power plant $>$ lignite, at mine $>$ disposal, spoil from lignite mining, in surface landfill 
SPA S6: Most important paths for marine ecotoxicity potential impacts of NCM life cycle

ABSOLUTE (kg-DCB-eq); RELATIVE (\%): SEQUENCE: >

0.0115998848; 20.87767762: Battery Use_NCM Li-Ion> Battery Assembly_NCM Li-Ion> Substrate_ Negative Electrode_Li-Ion> copper, primary, at refinery>copper concentrate, at beneficiation> disposal, sulfidic tailings, off-site

0.005406292186; 9.730340203: Battery Use_ NCM Li-Ion> Battery Assembly_ NCM Li-Ion> Substrate_ Negative Electrode_Li-Ion> copper, primary, at refinery

0.003567612249; 6.421051564: Battery Use_NCM Li-Ion> Battery Assembly_NCM Li-Ion> Battery Management System> integrated circuit, IC, logic type, at plant> gold, primary, at refinery> gold, at refinery> disposal, sulfidic tailings, off-site>

0.003496979999; 6.293926392: Battery Use_NCM Li-Ion> Battery Assembly_NCM Li-Ion> Battery Management System> integrated circuit, IC, logic type, at plant> gold, primary, at refinery> gold, at refinery> disposal, sulfidic tailings, off-site>

0.002908245692; 5.234311984: Battery Use_NCM Li-Ion> Electricity Consumed by Battery> electricity, medium voltage, production UCTE, at grid > electricity, high voltage, production UCTE, at grid> electricity, production mix UCTE $>$ electricity, production mix DE $>$ electricity, lignite, at power plant $>$ lignite, burned in power plant $>$ lignite, at mine $>$ disposal, spoil from lignite mining, in surface landfill

0.002094490068; 3.769700233: Battery Use_NCM Li-Ion> Battery Assembly_NCM Li-Ion> Battery Management System> copper, primary, at refinery> copper concentrate, at beneficiation> disposal, sulfidic tailings, off-site

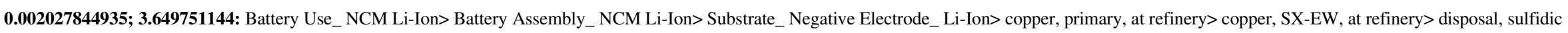
tailings, off-site

0.001762993191; 3.173066296: Battery Use_NCM Li-Ion> Battery Assembly_NCM Li-Ion> Positive Electrode Material_ NCM Li-Ion> Li[Ni0.4Co0.2Mn0.4]O2> Ni0.4Co0.2Mn0.4(OH)2> NiSO4> disposal, nickel smelter slag, $0 \%$ water, to residual material landfill>

0.001672085488; 3.009449005: Battery Use_NCM Li-Ion> Battery Assembly_NCM Li-Ion> Positive Electrode Material_ NCM Li-Ion> Li[Ni0.4Co0.2Mn0.4]O2> Ni0.4Co0.2Mn0.4(OH)2> NiSO4> disposal, sulfidic tailings, off-site>

0.001118710878; 2.013475604: Battery Use_NCM Li-Ion> Battery Assembly_NCM Li-Ion> Battery Management System> integrated circuit, IC, logic type, at plant> gold, primary, at refinery> gold, from combined gold-silver production, at refinery> disposal, sulfidic tailings, off-site>

0.001026591237; 1.847677048: Battery Use NCM Li-Ion> Electricity Consumed by Battery> electricity, medium voltage, production UCTE, at grid> electricity, high voltage, production UCTE, at grid> electricity, production mix UCTE $>$ electricity, production mix GR > electricity, lignite, at power plant $>$ lignite, burned in power plant $>$ lignite, at mine $>$ disposal, spoil from lignite mining, in surface landfill

0.001009056354; 1.816117455: Battery Use_NCM Li-Ion> Electricity Consumed by Battery> electricity, medium voltage, production UCTE, at grid> electricity, high voltage, production UCTE, at grid> electricity, production mix UCTE $>$ electricity, production mix PL $>$ electricity, lignite, at power plant> lignite, burned in power plant> lignite, at mine $>$ disposal, spoil from lignite mining, in surface landfill

0.0009761670471; 1.7569227: Battery Use_NCM Li-Ion> Battery Assembly_NCM Li-Ion> Battery Management System> copper, primary, at refinery

0.000949301272; 1.708569203: Battery Use_NCM Li-Ion> Battery Assembly_NCM Li-Ion> Battery Management System> integrated circuit, IC, logic type, at plant> gold, primary, at refinery> gold, from combined gold-silver production, at refinery> disposal, sulfidic tailings, off-site>

0.000805345215; 1.449474548: Battery Use_NCM Li-Ion> Battery Assembly_NCM Li-Ion> electricity, medium voltage, production UCTE, at grid> electricity, high voltage, production UCTE, at grid> electricity, production mix UCTE $>$ electricity, production mix DE $>$ electricity, lignite, at power plant $>$ lignite, burned in power plant $>$ lignite, at mine $>$ disposal, spoil from lignite mining, in surface landfill

0.0006150577028; 1.106991721: Battery Use_NCM Li-Ion> Electricity Consumed by Battery> electricity, medium voltage, production UCTE, at grid> electricity, high voltage, production UCTE, at grid> electricity, production mix UCTE > electricity, production mix CZ> electricity, lignite, at power plant $>$ lignite, burned in power plant> lignite, at mine $>$ disposal, spoil from lignite mining, in surface landfill 
SPA S7: Most important paths for global warming potential impacts of LFP life cycle

ABSOLUTE (kg CO2-eq); RELATIVE (\%): SEQUENCE

0.1214788503; 8.37916902: Battery Use_LFP Li-Ion > Battery Assembly_LFP Li-Ion> Positive Electrode Material_LFP Li-Ion> tetrafluoroethylene, at plant

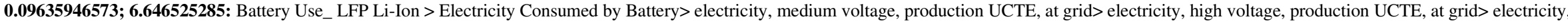
production mix UCTE $>$ electricity, production mix DE $>$ electricity, lignite, at power plant $>$ lignite, burned in power plant

0.07990355613; 5.511456526: Battery Use_LFP Li-Ion > Battery Assembly_LFP Li-Ion> Positive Electrode Material_LFP Li-Ion> tetrafluoroethylene, at plant> chlorodifluoromethane, at plant>

0.0680648857; 4.694868121: Battery Use_LFP Li-Ion > Electricity Consumed by Battery > electricity, medium voltage, production UCTE, at grid $>$ electricity, high voltage, production UCTE, at grid > electricity, production mix UCTE $>$ electricity, production mix DE $>$ electricity, hard coal, at power plant $>$ hard coal, burned in power plant

0.04542624037; 3.13333675: Battery Use_LFP Li-Ion > Battery Assembly_LFP Li-Ion $>$ heat, natural gas, at industrial furnace low-NOx $>100 \mathrm{~kW}>$ natural gas, burned in industrial furnace low-NOx $>100 \mathrm{~kW}$

0.04391897833; 3.0293713: Battery Use_LFP Li-Ion > Electricity Consumed by Battery > electricity, medium voltage, production UCTE, at grid> electricity, high voltage, production UCTE, at grid> electricity, production mix UCTE $>$ electricity, production mix PL $>$ electricity, hard coal, at power plant $>$ hard coal, burned in power plant

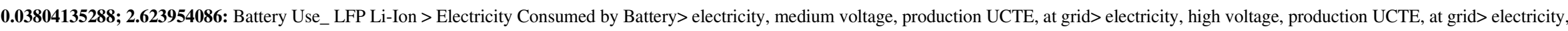
production mix UCTE $>$ electricity, production mix IT > electricity, natural gas, at power plant $>$ natural gas, burned in power plant

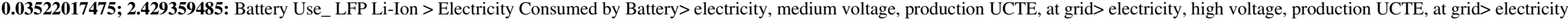
production mix UCTE > electricity, production mix ES> electricity, hard coal, at power plant> hard coal, burned in power plant

0.03097330117; 2.1364256: Battery Use_LFP Li-Ion > Electricity Consumed by Battery > electricity, medium voltage, production UCTE, at grid > electricity, high voltage, production UCTE, at grid> electricity, production mix UCTE > electricity, production mix PL > electricity, lignite, at power plant> lignite, burned in power plant

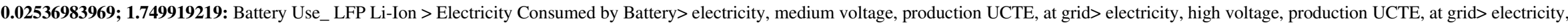
production mix UCTE > electricity, production mix CZ> electricity, lignite, at power plant> lignite, burned in power plant

0.02454023214; 1.692695909: Battery Use_LFP Li-Ion > Battery Assembly_LFP Li-Ion> Negative Electrode Material_Carbon_Li-Ion> tetrafluoroethylene, at plant

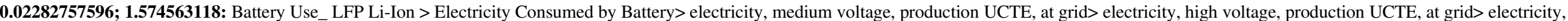
production mix UCTE > electricity, production mix GR> electricity, lignite, at power plant> lignite, burned in power plant

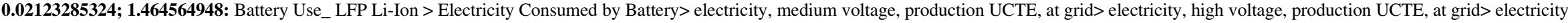
production mix UCTE > electricity, production mix IT> electricity, hard coal, at power plant> hard coal, burned in power plant

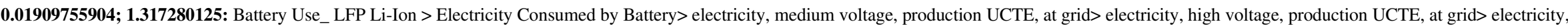
production mix UCTE $>$ electricity, production mix IT > electricity, oil, at power plant> heavy fuel oil, burned in power plant

0.01817547635; 1.253678216: Battery Use_LFP Li-Ion > Electricity Consumed by Battery> electricity, medium voltage, production UCTE, at grid> electricity, high voltage, production UCTE, at grid > electricity, production mix UCTE $>$ electricity, production mix NL $>$ electricity, natural gas, at power plant $>$ natural gas, burned in power plant

0.0175330133; 1.209363453: Battery Use__LFP Li-Ion > Electricity Consumed by Battery> electricity, medium voltage, production UCTE, at grid > electricity, high voltage, production UCTE, at grid > electricity, production mix UCTE> electricity, production mix CS> electricity, lignite, at power plant> lignite, burned in power plant 
SPA S8: Most important paths for ozone depletion potential impacts of LFP life cycle

ABSOLUTE (kg CFC-11-eq); RELATIVE (\%): SEQUENCE

3.555761239e-06; 47.62642565: Battery Use_LFP Li-Ion > Battery Assembly_LFP Li-Ion> Positive Electrode Material_LFP Li-Ion> tetrafluoroethylene, at plant

1.379044274e-06; 18.47113605: Battery Use_LFP Li-Ion > Battery Assembly_LFP Li-Ion> Positive Electrode Material_LFP Li-Ion> tetrafluoroethylene, at plant> chlorodifluoromethane, at plant> trichloromethane, at plant

1.206073396e-06; 16.15433688: Battery Use__LFP Li-Ion > Battery Assembly_LFP Li-Ion> Positive Electrode Material_LFP Li-Ion> tetrafluoroethylene, at plant> chlorodifluoromethane, at plant

7.183078044e-07; 9.621127783: Battery Use_LFP Li-Ion > Battery Assembly_LFP Li-Ion> Negative Electrode Material_Carbon_Li-Ion> tetrafluoroethylene, at plant

2.785840213e-07; 3.731398227: Battery Use_LFP Li-Ion > Battery Assembly_LFP Li-Ion> Negative Electrode Material_Carbon_Li-Ion> tetrafluoroethylene, at plant> chlorodifluoromethane, at plant> trichloromethane, at plant

2.436417618e-07; 3.263376103: Battery Use__LFP Li-Ion > Battery Assembly_LFP Li-Ion> Negative Electrode Material_Carbon_Li-Ion> tetrafluoroethylene, at plant> chlorodifluoromethane, at plant 


\section{Sensitivity Analysis}

In order to have a better grasp on the confidence intervals associated with our main results, a sensitivity analysis was performed. Selected battery characteristics and production parameters were altered, and the impacts of these alterations on the final mid-point indicator results was assessed (Table S30). For this analysis, we selected parameters we deemed would have the strongest impact, and the relative alterations strive to be representative of the inhomogeneity of the system. 
Table S30: Sensitivity Analysis

\begin{tabular}{|c|c|c|c|c|c|c|c|}
\hline \multirow[t]{2}{*}{ FU: Charge-discharge $50 \mathrm{MJ}$} & & \multicolumn{3}{|c|}{ Control } & \multicolumn{3}{|c|}{ Chinese Electricity Mix } \\
\hline & & NCM & LFP & NIMH & NCM & LFP & NIMH \\
\hline climate change & $\mathrm{kg} \mathrm{CO}_{2}-\mathrm{eq}$ & $1.9 \mathrm{E}+0$ & $1.4 \mathrm{E}+0$ & $3.5 \mathrm{E}+0$ & $2.1 \mathrm{E}+0$ & $1.6 \mathrm{E}+0$ & $4.1 \mathrm{E}+0$ \\
\hline fossil depletion & kg oil-eq & $4.5 \mathrm{E}-1$ & $3.7 \mathrm{E}-1$ & $9.9 \mathrm{E}-1$ & $4.9 \mathrm{E}-1$ & $3.9 \mathrm{E}-1$ & $1.1 \mathrm{E}+0$ \\
\hline freshwater ecotoxicity & kg 1,4-DCB-eq & $5.1 \mathrm{E}-2$ & $3.4 \mathrm{E}-2$ & $1.3 \mathrm{E}-1$ & $5.0 \mathrm{E}-2$ & $3.3 \mathrm{E}-2$ & $1.2 \mathrm{E}-1$ \\
\hline freshwater eutrophication & kg P-eq & $2.7 \mathrm{E}-3$ & $2.0 \mathrm{E}-3$ & $4.5 \mathrm{E}-3$ & $2.6 \mathrm{E}-3$ & $1.9 \mathrm{E}-3$ & $4.2 \mathrm{E}-3$ \\
\hline human toxicity & kg 1,4-DCB-eq & $4.1 \mathrm{E}+0$ & $2.7 \mathrm{E}+0$ & $5.6 \mathrm{E}+0$ & $4.0 \mathrm{E}+0$ & $2.6 \mathrm{E}+0$ & $5.4 \mathrm{E}+0$ \\
\hline marine ecotoxicity & kg 1,4-DCB-eq & $5.6 \mathrm{E}-2$ & 3.7E-2 & $1.3 \mathrm{E}-1$ & $5.4 \mathrm{E}-2$ & $3.6 \mathrm{E}-2$ & $1.3 \mathrm{E}-1$ \\
\hline marine eutrophication & kg N-eq & $2.5 \mathrm{E}-3$ & $1.9 \mathrm{E}-3$ & $4.0 \mathrm{E}-3$ & $2.5 \mathrm{E}-3$ & $1.9 \mathrm{E}-3$ & $4.0 \mathrm{E}-3$ \\
\hline metal depletion & $\mathrm{kg} \mathrm{Fe}$-eq & $8.5 \mathrm{E}-1$ & $3.0 \mathrm{E}-1$ & $1.1 \mathrm{E}+0$ & $8.5 \mathrm{E}-1$ & $3.0 \mathrm{E}-1$ & $1.1 \mathrm{E}+0$ \\
\hline ozone depletion & kg CFC-11-eq & $1.1 \mathrm{E}-5$ & $7.5 \mathrm{E}-6$ & $1.0 \mathrm{E}-5$ & $1.1 \mathrm{E}-5$ & $7.5 \mathrm{E}-6$ & $1.0 \mathrm{E}-5$ \\
\hline particulate matter formation & kg PM10-eq & $3.6 \mathrm{E}-3$ & $2.1 \mathrm{E}-3$ & $2.3 \mathrm{E}-2$ & 4.6E-3 & $2.7 \mathrm{E}-3$ & $2.6 \mathrm{E}-2$ \\
\hline photochemical oxidant formation & kg NMVOC & $4.5 \mathrm{E}-3$ & $3.0 \mathrm{E}-3$ & $1.7 \mathrm{E}-2$ & $5.8 \mathrm{E}-3$ & $3.8 \mathrm{E}-3$ & $2.0 \mathrm{E}-2$ \\
\hline terrestrial acidification & $\mathrm{kg} \mathrm{SO}_{2}$-eq & $1.2 \mathrm{E}-2$ & $6.5 \mathrm{E}-3$ & $9.8 \mathrm{E}-2$ & $1.5 \mathrm{E}-2$ & $8.4 \mathrm{E}-3$ & $1.1 \mathrm{E}-1$ \\
\hline \multirow[t]{3}{*}{ terrestrial ecotoxicity } & kg 1,4-DCB-eq & $3.1 \mathrm{E}-4$ & $1.7 \mathrm{E}-4$ & $1.2 \mathrm{E}-3$ & $3.0 \mathrm{E}-4$ & $1.7 \mathrm{E}-4$ & $1.2 \mathrm{E}-3$ \\
\hline & & \multicolumn{3}{|c|}{$-5 \%$ Efficiency } & \multicolumn{3}{|c|}{$+5 \%$ Efficiency } \\
\hline & & NCM & LFP & NIMH & NCM & LFP & NIMH \\
\hline climate change & $\mathrm{kg} \mathrm{CO}_{2}-\mathrm{eq}$ & $2.2 \mathrm{E}+0$ & $1.8 \mathrm{E}+0$ & $3.8 \mathrm{E}+0$ & $1.5 \mathrm{E}+0$ & $1.1 \mathrm{E}+0$ & $3.2 \mathrm{E}+0$ \\
\hline fossil depletion & kg oil-eq & $5.5 \mathrm{E}-1$ & $4.6 \mathrm{E}-1$ & $1.1 \mathrm{E}+0$ & 3.6E-1 & $2.7 \mathrm{E}-1$ & $9.0 \mathrm{E}-1$ \\
\hline ecotoxicity & kg 1,4-DCB-eq & $5.6 \mathrm{E}-2$ & $3.8 \mathrm{E}-2$ & $1.3 \mathrm{E}-1$ & 4.7E-2 & $2.9 \mathrm{E}-2$ & $1.2 \mathrm{E}-1$ \\
\hline freshwater eutrophication & kg P-eq & $3.0 \mathrm{E}-3$ & $2.4 \mathrm{E}-3$ & $4.8 \mathrm{E}-3$ & $2.4 \mathrm{E}-3$ & $1.7 \mathrm{E}-3$ & $4.3 \mathrm{E}-3$ \\
\hline human toxicity & kg 1,4-DCB-eq & $4.3 \mathrm{E}+0$ & $2.9 \mathrm{E}+0$ & $5.8 \mathrm{E}+0$ & $3.9 \mathrm{E}+0$ & $2.4 \mathrm{E}+0$ & $5.4 \mathrm{E}+0$ \\
\hline marine ecotoxicity & kg 1,4-DCB-eq & $6.0 \mathrm{E}-2$ & 4.1E-2 & $1.4 \mathrm{E}-1$ & $5.1 \mathrm{E}-2$ & $3.2 \mathrm{E}-2$ & $1.3 \mathrm{E}-1$ \\
\hline marine eutrophication & kg N-eq & $2.9 \mathrm{E}-3$ & $2.2 \mathrm{E}-3$ & $4.4 \mathrm{E}-3$ & $2.1 \mathrm{E}-3$ & $1.5 \mathrm{E}-3$ & $3.7 \mathrm{E}-3$ \\
\hline metal depletion & kg Fe-eq & $8.5 \mathrm{E}-1$ & $3.1 \mathrm{E}-1$ & $1.1 \mathrm{E}+0$ & $8.4 \mathrm{E}-1$ & $3.0 \mathrm{E}-1$ & $1.1 \mathrm{E}+0$ \\
\hline ozone depletion & kg CFC-11-eq & $1.1 \mathrm{E}-5$ & $7.5 \mathrm{E}-6$ & $1.0 \mathrm{E}-5$ & $1.1 \mathrm{E}-5$ & 7.4E-6 & $1.0 \mathrm{E}-5$ \\
\hline particulate matter formation & kg PM10-eq & $4.1 \mathrm{E}-3$ & $2.5 \mathrm{E}-3$ & $2.4 \mathrm{E}-2$ & $3.2 \mathrm{E}-3$ & $1.7 \mathrm{E}-3$ & 2.3E-2 \\
\hline photochemical oxidant formation & $\mathrm{kg}$ NMVOC & $5.2 \mathrm{E}-3$ & $3.7 \mathrm{E}-3$ & $1.8 \mathrm{E}-2$ & $3.8 \mathrm{E}-3$ & $2.3 \mathrm{E}-3$ & $1.6 \mathrm{E}-2$ \\
\hline terrestrial acidification & $\mathrm{kg} \mathrm{SO}_{2}$-eq & $1.4 \mathrm{E}-2$ & $7.9 \mathrm{E}-3$ & $9.9 \mathrm{E}-2$ & $1.1 \mathrm{E}-2$ & $5.1 \mathrm{E}-3$ & $9.7 \mathrm{E}-2$ \\
\hline \multirow[t]{3}{*}{ terrestrial ecotoxicity } & kg 1,4-DCB-eq & $3.3 \mathrm{E}-4$ & $2.0 \mathrm{E}-4$ & $1.2 \mathrm{E}-3$ & $2.8 \mathrm{E}-4$ & $1.5 \mathrm{E}-4$ & $1.2 \mathrm{E}-3$ \\
\hline & & \multicolumn{3}{|c|}{$-25 \%$ Density } & \multicolumn{3}{|c|}{$+25 \%$ Density } \\
\hline & & NCM & LFP & NIMH & NCM & LFP & NIMH \\
\hline climate change & $\mathrm{kg} \mathrm{CO}_{2}-\mathrm{eq}$ & $2.0 \mathrm{E}+0$ & $1.5 \mathrm{E}+0$ & $3.9 \mathrm{E}+0$ & $1.8 \mathrm{E}+0$ & $1.4 \mathrm{E}+0$ & $3.3 \mathrm{E}+0$ \\
\hline fossil de & kg oil-eq & $4.9 \mathrm{E}-1$ & $3.9 \mathrm{E}-1$ & $1.1 \mathrm{E}+0$ & $4.3 \mathrm{E}-1$ & $3.5 \mathrm{E}-1$ & $9.3 \mathrm{E}-1$ \\
\hline freshwater ecotoxicity & $\mathrm{kg} \mathrm{1,4-DCB-eq}$ & $6.7 \mathrm{E}-2$ & $4.4 \mathrm{E}-2$ & $1.7 \mathrm{E}-1$ & $4.2 \mathrm{E}-2$ & $2.8 \mathrm{E}-2$ & $1.0 \mathrm{E}-1$ \\
\hline freshwater eutrophication & kg P-eq & $3.5 \mathrm{E}-3$ & $2.5 \mathrm{E}-3$ & $5.6 \mathrm{E}-3$ & $2.3 \mathrm{E}-3$ & $1.7 \mathrm{E}-3$ & $3.9 \mathrm{E}-3$ \\
\hline human toxicity & kg 1,4-DCB-eq & $5.7 \mathrm{E}+0$ & $3.7 \mathrm{E}+0$ & $7.3 \mathrm{E}+0$ & $3.1 \mathrm{E}+0$ & $2.0 \mathrm{E}+0$ & $4.5 \mathrm{E}+0$ \\
\hline marine ecotoxicity & kg 1,4-DCB-eq & $7.4 \mathrm{E}-2$ & $4.8 \mathrm{E}-2$ & $1.8 \mathrm{E}-1$ & $4.4 \mathrm{E}-2$ & $2.9 \mathrm{E}-2$ & $1.1 \mathrm{E}-1$ \\
\hline marine eutrophication & $\mathrm{kg} \mathrm{N}$-eq & $2.8 \mathrm{E}-3$ & $2.0 \mathrm{E}-3$ & $4.7 \mathrm{E}-3$ & $2.4 \mathrm{E}-3$ & $1.8 \mathrm{E}-3$ & $3.6 \mathrm{E}-3$ \\
\hline metal depletion & kg Fe-eq & $1.1 \mathrm{E}+0$ & $4.5 \mathrm{E}-1$ & $1.6 \mathrm{E}+0$ & 7.1E-1 & $2.2 \mathrm{E}-1$ & 8.3E-1 \\
\hline ozone depletion & kg CFC-11-eq & $1.1 \mathrm{E}-5$ & $7.5 \mathrm{E}-6$ & $1.0 \mathrm{E}-5$ & $1.1 \mathrm{E}-5$ & $7.5 \mathrm{E}-6$ & $1.0 \mathrm{E}-5$ \\
\hline particulate matter formation & kg PM10-eq & $4.3 \mathrm{E}-3$ & $2.5 \mathrm{E}-3$ & $3.2 \mathrm{E}-2$ & $3.2 \mathrm{E}-3$ & $1.8 \mathrm{E}-3$ & $1.8 \mathrm{E}-2$ \\
\hline photochemical oxidant formation & $\mathrm{kg}$ NMVOC & $5.2 \mathrm{E}-3$ & $3.5 \mathrm{E}-3$ & $2.2 \mathrm{E}-2$ & 4.1E-3 & $2.8 \mathrm{E}-3$ & $1.4 \mathrm{E}-2$ \\
\hline terrestrial acidification & $\mathrm{kg} \mathrm{SO}_{2}$-eq & $1.4 \mathrm{E}-2$ & 7.7E-3 & $1.4 \mathrm{E}-1$ & $1.1 \mathrm{E}-2$ & $5.7 \mathrm{E}-3$ & $7.6 \mathrm{E}-2$ \\
\hline terrestrial ecotoxicity & kg 1,4-DCB-eq & 3.9E-4 & $2.3 \mathrm{E}-4$ & $1.5 \mathrm{E}-3$ & $2.6 \mathrm{E}-4$ & $1.4 \mathrm{E}-4$ & 9.7E-4 \\
\hline
\end{tabular}


Table S30: Sensitivity Analysis (cont'd)

\begin{tabular}{|c|c|c|c|c|c|c|c|}
\hline & & \multicolumn{3}{|c|}{$-33 \%$ lifetime } & \multicolumn{3}{|c|}{$+33 \%$ lifetime } \\
\hline & & NCM & LFP & NIMH & NCM & LFP & NIMH \\
\hline climate change & $\mathrm{kg} \mathrm{CO}_{2}$-eq & $2.4 \mathrm{E}+0$ & $1.8 \mathrm{E}+0$ & $4.6 \mathrm{E}+0$ & $1.6 \mathrm{E}+0$ & $1.3 \mathrm{E}+0$ & $3.0 \mathrm{E}+0$ \\
\hline fossil depletion & kg oil-eq & $5.8 \mathrm{E}-1$ & $4.4 \mathrm{E}-1$ & $1.3 \mathrm{E}+0$ & $3.9 \mathrm{E}-1$ & $3.3 \mathrm{E}-1$ & $8.5 \mathrm{E}-1$ \\
\hline freshwater ecotoxicity & kg 1,4-DCB-eq & $7.2 \mathrm{E}-2$ & 4.6E-2 & $1.8 \mathrm{E}-1$ & 4.1E-2 & $2.8 \mathrm{E}-2$ & 9.9E-2 \\
\hline freshwater eutrophication & kg P-eq & $3.7 \mathrm{E}-3$ & $2.7 \mathrm{E}-3$ & $6.1 \mathrm{E}-3$ & $2.2 \mathrm{E}-3$ & $1.7 \mathrm{E}-3$ & $3.8 \mathrm{E}-3$ \\
\hline human toxicity & kg 1,4-DCB-eq & $5.9 \mathrm{E}+0$ & $3.8 \mathrm{E}+0$ & $7.9 \mathrm{E}+0$ & $3.2 \mathrm{E}+0$ & $2.1 \mathrm{E}+0$ & $4.4 \mathrm{E}+0$ \\
\hline marine ecotoxicity & kg 1,4-DCB-eq & $7.8 \mathrm{E}-2$ & $5.0 \mathrm{E}-2$ & $1.9 \mathrm{E}-1$ & $4.4 \mathrm{E}-2$ & $3.0 \mathrm{E}-2$ & $1.1 \mathrm{E}-1$ \\
\hline marine eutrophication & kg N-eq & $3.4 \mathrm{E}-3$ & $2.4 \mathrm{E}-3$ & $5.2 \mathrm{E}-3$ & $2.1 \mathrm{E}-3$ & $1.6 \mathrm{E}-3$ & $3.4 \mathrm{E}-3$ \\
\hline metal depletion & kg Fe-eq & $1.3 \mathrm{E}+0$ & $4.5 \mathrm{E}-1$ & $1.7 \mathrm{E}+0$ & $6.4 \mathrm{E}-1$ & 2.3E-1 & $8.4 \mathrm{E}-1$ \\
\hline ozone depletion & kg CFC-11-eq & $1.7 \mathrm{E}-5$ & $1.1 \mathrm{E}-5$ & $1.5 \mathrm{E}-5$ & $8.6 \mathrm{E}-6$ & $5.6 \mathrm{E}-6$ & $7.8 \mathrm{E}-6$ \\
\hline particulate matter formation & kg PM10-eq & $5.0 \mathrm{E}-3$ & 2.7E-3 & $3.4 \mathrm{E}-2$ & $3.0 \mathrm{E}-3$ & $1.8 \mathrm{E}-3$ & $1.8 \mathrm{E}-2$ \\
\hline photochemical oxidant formation & kg NMVOC & $5.9 \mathrm{E}-3$ & $3.8 \mathrm{E}-3$ & $2.4 \mathrm{E}-2$ & $3.7 \mathrm{E}-3$ & $2.7 \mathrm{E}-3$ & $1.4 \mathrm{E}-2$ \\
\hline terrestrial acidification & $\mathrm{kg} \mathrm{SO}_{2}$-eq & $1.7 \mathrm{E}-2$ & $8.2 \mathrm{E}-3$ & $1.4 \mathrm{E}-1$ & $9.9 \mathrm{E}-3$ & $5.6 \mathrm{E}-3$ & 7.5E-2 \\
\hline \multirow[t]{3}{*}{ terrestrial ecotoxicity } & kg 1,4-DCB-eq & 4.3E-4 & $2.3 \mathrm{E}-4$ & $1.7 \mathrm{E}-3$ & $2.4 \mathrm{E}-4$ & $1.5 \mathrm{E}-4$ & $9.1 \mathrm{E}-4$ \\
\hline & & \multicolumn{3}{|c|}{-33\% Manufacture Energy } & \multicolumn{3}{|c|}{ +33\% Manufacture Energy } \\
\hline & & NCM & LFP & NIMH & NCM & LFP & NIMH \\
\hline climate change & $\mathrm{kg} \mathrm{CO}$-eq & $1.8 \mathrm{E}+0$ & $1.4 \mathrm{E}+0$ & $3.3 \mathrm{E}+0$ & $2.0 \mathrm{E}+0$ & $1.5 \mathrm{E}+0$ & $3.8 \mathrm{E}+0$ \\
\hline fossil depletion & kg oil-eq & $4.2 \mathrm{E}-1$ & $3.4 \mathrm{E}-1$ & $9.1 \mathrm{E}-1$ & $4.9 \mathrm{E}-1$ & 3.9E-1 & $1.1 \mathrm{E}+0$ \\
\hline freshwater ecotoxicity & kg 1,4-DCB-eq & $5.0 \mathrm{E}-2$ & $3.3 \mathrm{E}-2$ & $1.2 \mathrm{E}-1$ & $5.2 \mathrm{E}-2$ & $3.4 \mathrm{E}-2$ & $1.3 \mathrm{E}-1$ \\
\hline freshwater eutrophication & kg P-eq & $2.7 \mathrm{E}-3$ & $2.0 \mathrm{E}-3$ & $4.4 \mathrm{E}-3$ & $2.8 \mathrm{E}-3$ & $2.1 \mathrm{E}-3$ & 4.7E-3 \\
\hline human toxicity & kg 1,4-DCB-eq & $4.1 \mathrm{E}+0$ & $2.6 \mathrm{E}+0$ & $5.5 \mathrm{E}+0$ & $4.2 \mathrm{E}+0$ & $2.7 \mathrm{E}+0$ & $5.7 \mathrm{E}+0$ \\
\hline marine ecotoxicity & kg 1,4-DCB-eq & $5.5 \mathrm{E}-2$ & $3.6 \mathrm{E}-2$ & $1.3 \mathrm{E}-1$ & $5.7 \mathrm{E}-2$ & $3.7 \mathrm{E}-2$ & $1.4 \mathrm{E}-1$ \\
\hline marine eutrophication & kg N-eq & $2.4 \mathrm{E}-3$ & $1.8 \mathrm{E}-3$ & $3.8 \mathrm{E}-3$ & $2.6 \mathrm{E}-3$ & $1.9 \mathrm{E}-3$ & $4.2 \mathrm{E}-3$ \\
\hline metal depletion & kg Fe-eq & $8.5 \mathrm{E}-1$ & $3.0 \mathrm{E}-1$ & $1.1 \mathrm{E}+0$ & $8.5 \mathrm{E}-1$ & $3.1 \mathrm{E}-1$ & $1.1 \mathrm{E}+0$ \\
\hline ozone depletion & kg CFC-11-eq & $1.1 \mathrm{E}-5$ & $7.5 \mathrm{E}-6$ & $1.0 \mathrm{E}-5$ & $1.1 \mathrm{E}-5$ & $7.5 \mathrm{E}-6$ & $1.0 \mathrm{E}-5$ \\
\hline particulate matter formation & kg PM10-eq & $3.5 \mathrm{E}-3$ & $2.0 \mathrm{E}-3$ & 2.3E-2 & 3.7E-3 & $2.2 \mathrm{E}-3$ & $2.4 \mathrm{E}-2$ \\
\hline photochemical oxidant formation & kg NMVOC & 4.3E-3 & $2.9 \mathrm{E}-3$ & $1.7 \mathrm{E}-2$ & 4.7E-3 & $3.2 \mathrm{E}-3$ & $1.7 \mathrm{E}-2$ \\
\hline terrestrial acidification & $\mathrm{kg} \mathrm{SO}_{2}$-eq & $1.2 \mathrm{E}-2$ & $6.3 \mathrm{E}-3$ & $9.7 \mathrm{E}-2$ & $1.2 \mathrm{E}-2$ & $6.7 \mathrm{E}-3$ & $9.9 \mathrm{E}-2$ \\
\hline terrestrial ecotoxicity & kg 1,4-DCB-eq & $3.0 \mathrm{E}-4$ & $1.7 \mathrm{E}-4$ & $1.2 \mathrm{E}-3$ & $3.1 \mathrm{E}-4$ & $1.8 \mathrm{E}-4$ & $1.2 \mathrm{E}-3$ \\
\hline
\end{tabular}




\section{Reference}

(1) Frischknecht, R.; Doka, G.; Dones, R.; Heck, T.; Hellweg, S.; Hischier, R.; Nemecek, T.; Rebitzer, G.; Spielmann, M.; Wernet, G. Overview and Methodology. Ecoinvent v2.0 Reports; Dübendorf, 2007; Vol. 01.

(2) Kalhammer, F. R.; Kopf, B. M.; Swan, D. H.; Roan, V. P.; Walsh, M. P. Status and Prospects for Zero Emissions Vehicle Technology; State of California Air Resources Board: Sacramento, California, 2007.

(3) Ragone, D. V. Review of battery systems for electrically powered vehicles; In SAE Transactions; Detroit, 1968; Vol. 77.

(4) Gaines, L.; Cuenca, R. Costs of lithium-ion batteries for vehicles; Argonne National Laboratory, Center for Transportation Research: Argonne, Illinois, 2000.

(5) Axsen, J.; Burke, A.; Kurani, K. Batteries for plug-in hybrid electric vehicles (PHEVs): goals and the state of technology circa 2008; Davis, California, 2008.

(6) Gaines, L.; Nelson, P. Lithium-Ion Batteries : Possible Materials Issues; Argonne National Laboratory: Argonne, IL, 2009.

(7) Schexnayder, S. M.; Das, S.; Dhingra, R.; Overly, J. G.; Tonn, B. E.; Peretz, J. H.; Waidley, G.; Davis, G. A. Environmental Evaluation of New Generation Vehicles and Vehicle Components; Oak Ridge National Laboratory, US Department of Energy: Washington, D.C., 2001; p. 133.

(8) Ying, T.; Gao, X.; Hu, W.; Wu, F.; Noreus, D. Studies on rechargeable NiMH batteries. Int. J. Hydrogen Energy 2006, 31, 525-530.

(9) Singh, M.; Cuenca, R.; Formento, J.; Gaines, L.; Man, B.; Santini, D.; Wang, M.; Adelman, S.; Kline, D.; Mark, J.; Ohi, J.; Rau, N.; Freeman, S.; Humphreys, K.; Placet, M. Total energy cycle assessment of electric and conventional vehicles: An energy and environmental analysis; Argonne National Laboratory, Argonne, Ill: Argonne, Illinois, 1998; Vol. ANL/ES/RP-, p. 233.

(10) Hamann, C. H.; Hamnett, A.; Vielstich, W. Electrochemistry; 2nd ed.; Wiley-VCH: Weinheim, 2007.

(11) Linden, D.; Magnusen, D. Portable sealed nickel-metal hydride batteries; In Handbook of Batteries; Linden, D.; Reddy, T. B., Eds.; McGraw-Hill: New York, 2002; pp. 1-35.

(12) Ngala, J. K.; Chernova, N. A.; Ma, M.; Mamak, M.; Zavalij, P. Y.; Whittingham, M. S. The synthesis, characterization and electrochemical behavior of the layered $\mathrm{LiNi} 0.4 \mathrm{Mn} 0.4 \mathrm{Co} 0.2 \mathrm{O} 2$ compound. J. Mater. Chem. 2004, 14, 214.

(13) Shukla, A. K.; Kumar, T. P. Materials for next-generation lithium batteries. Curr. Sci. 2008, 93, 314-331.

(14) Chen, J.; Whittingham, M. S. Hydrothermal synthesis of lithium iron phosphate. Electrochem. commun. 2006, 8, 855-858. 
(15) Liu, Z. Synthesis and characterization of LiNi1-x-yCoxMnyO2 as the cathode materials of secondary lithium batteries. J. Power Sources 1999, 81-82, 416-419.

(16) Arnold, G. Fine-particle lithium iron phosphate LiFePO4 synthesized by a new low-cost aqueous precipitation technique. J. Power Sources 2003, 119-121, 247-251.

(17) Le Cras, F.; Franger, S.; Bourbon, C.; Rouault, H. Comparison between different LiFePO4 synthesis routes and their influence on its physico-chemical properties. J. Power Sources 2003, 119-121, 252-257.

(18) Yoshio, M.; Wang, H.; Fukuda, K.; Umeno, T.; Abe, T.; Ogumi, Z. Improvement of natural graphite as a lithium-ion battery anode material, from raw flake to carbon-coated sphere. $J$. Mater. Chem. 2004, 14, 1754.

(19) Ikeya, T. Multi-step constant-current charging method for an electric vehicle nickel/metal hydride battery with high-energy efficiency and long cycle life. J. Power Sources 2002, 105, 6-12.

(20) Karden, E.; Ploumen, S.; Fricke, B.; Miller, T.; Snyder, K. Energy storage devices for future hybrid electric vehicles. J. Power Sources 2007, 168, 2-11.

(21) Shiau, C.-S. N.; Samaras, C.; Hauffe, R.; Michalek, J. J. Impact of battery weight and charging patterns on the economic and environmental benefits of plug-in hybrid vehicles. Energy Policy 2009, 37, 2653-2663.

(22) Van Den Bossche, P.; Vergels, F.; Van Mierlo, J.; Matheys, J.; Van Autenboer, W. SUBAT: An assessment of sustainable battery technology. J. Power Sources 2006, 162, 913-919.

(23) Tanaka, T.; Ohta, K.; Arai, N. Year 2000 RI\&D status of large-scale lithium ion secondary batteries in the national project of Japan. J. Power Sources 2001, 97, 2-6.

(24) Kokam Superior Lithium Polymer Battery (SLPB) Cell Specification Data; Kokam Co. Ltd: Korea, 2006.

(25) Takahashi, M.; Ohtsuka, H.; Akuto, K.; Sakurai, Y. Confirmation of Long-Term Cyclability and High Thermal Stability of LiFePO[sub 4] in Prismatic Lithium-Ion Cells. J. Electrochem. Soc. 2005, 152, A899.

(26) Rydh, C. J.; Sandén, B. A. Energy analysis of batteries in photovoltaic systems. Part I: Performance and energy requirements. Energy Convers. Manage. 2005, 46, 1957-1979.

(27) Deveney, B.; Nechev, K.; Guseynov, T.; Jow, R.; Xu, K. Large Size Lithium Ion Cells Based on LiFePO 4 Cathode Material; In Tenth Electrochemical Power Source Research and Development Symposium; 2008.

(28) Cheret, D. Battery Collection and Recycling; In Industrial Applications of Batteries. From Cars to Aerospace and Energy Storage; Broussely, M.; Pistoia, G., Eds.; Elsevier: Amsterdam, 2007; pp. 691-702.

(29) Distances Between ports, eleventh edition, Pub. 151; National Imagery and Mapping Agency, United States Government: Bethesda, Maryland, 2001; Vol. 397, pp. 1-126. 
(30) Wakihara, M. Recent developments in lithium ion batteries. Materials Science and Engineering R33: R Reports 2001, 33, 109-134.

(31) Hischier, R.; Classen, M.; Lehmann, M.; Scharnhorst, W. Life cycle inventories of Electric and Electronic Equipment: Production, Use and Disposal. Ecoinvent v2.0; Swiss Centre for Life Cycle Inventories: Dübendorf, 2007; Vol. 18.

(32) Burnham, A.; Wang, M.; Wu, Y. Development and Applications of GREET 2.7 - The Transportation Vehicle-Cycle Model; Argonne National Laboratory: Chicago, 2006; Vol. ANL/ESD/06.

(33) Zhang, S.; Jow, T. R. Study of poly(acrylonitrile-methyl methacrylate) as binder for graphite anode and LiMn2O4 cathode of Li-ion batteries. J. Power Sources 2002, 109, 422-426.

(34) Yang, S. Hydrothermal synthesis of lithium iron phosphate cathodes. Electrochem. commun. 2001, 3, 505-508.

(35) Whittingham, M. S. Lithium Batteries and Cathode Materials. Chem. Rev. 2004, 104, 4271-4302.

(36) Dominko, R.; Gaberscek, M.; Drofenik, J.; Bele, M.; Pejovnik, S.; Jamnik, J. The role of carbon black distribution in cathodes for Li ion batteries. J. Power Sources 2003, 119, 770-773.

(37) Stura, E.; Nicolini, C. New nanomaterials for light weight lithium batteries. Anal. Chim. Acta. 2006, 568, 57-64.

(38) Park, M.-H.; Kim, M. G.; Joo, J.; Kim, K.; Kim, J.; Ahn, S.; Cui, Y.; Cho, J. Silicon Nanotube Battery Anodes. Nano Lett. 2009, .

(39) Kim, H.; Cho, J. Superior lithium electroactive mesoporous Si@ carbon core-shell nanowires for lithium battery anode material. Nano Lett. 2008, 8, 3688-91.

(40) Chan, C. K.; Zhang, X. F.; Cui, Y. High capacity Li ion battery anodes using Ge nanowires. Nano Lett. 2008, 8, 307-309.

(41) Aurbach, D.; Markovsky, B.; Salitra, G.; Markevich, E.; Talyossef, Y.; Koltypin, M.; Nazar, L.; Ellis, B.; Kovacheva, D. Review on electrode-electrolyte solution interactions, related to cathode materials for Li-ion batteries. J. Power Sources 2007, 165, 491-499.

(42) Aurbach, D.; Talyosef, Y.; Markovsky, B.; Markevich, E.; Zinigrad, E.; Asraf, L.; Gnanaraj, J.; Kim, H. Design of electrolyte solutions for Li and Li-ion batteries: a review. Electrochim. Acta 2004, 50, 247-254.

(43) Kanamura, K.; Koizumi, S.; Dokko, K. Hydrothermal synthesis of LiFePO4 as a cathode material for lithium batteries. J. Mater. Sci. 2007, 43, 2138-2142.

(44) Nabertherm. Thermal Process Technology; Lilienthal, Germany, 2010.

(45) Zhang, L. Batteries, Rechargeable; In Encyclopedia of Materials - Science and Technology -volumes 1-11; Buschow, K. H. J.; Cahn, R. W.; Flemings, M. C.; Ilschner, B.; Kramer, E. J.; Mahajan, S., Eds.; Elsevier: Amsterdam, 2001. 
(46) Müller, T.; Friedrich, B. Development of a recycling process for nickel-metal hydride batteries. $J$. Power Sources 2006, 158, 1498-1509.

(47) Szajek, a The electronic and electrochemical properties of the LaNi5, LaNi4Al and LaNi3AlCo systems. J. Alloys Compd. 2000, 307, 290-296.

(48) Sakai, T.; Yoshinaga, H.; Miyamura, H.; Kuriyama, N.; Ishikawa, H. Rechargeable hydrogen batteries using rare-earth-based hydrogen storage alloys. J. Alloys Compd. 1992, 180, 37-54.

(49) Srivastava, S.; Raman, S.; Singh, B.; Srivastava, O. On the synthesis and characterization of some new AB5 type MmNi4. 3A10. 3Mn0. 4, LaNi5-xSix ( $\mathrm{x}=0.1,0.3,0.5)$ and $\mathrm{Mg}-\mathrm{x}$ wt\% CFMmNi5-y wt\% Si hydrogen storage materials. Int. J. Hydrogen Energy 2000, 25, 431-440.

(50) Yang, D.-C.; Jang, I.-S.; Jang, M.-H.; Park, C.-N.; Park, C.-J.; Choi, J. Optimization of additive compositions for anode in Ni-MH secondary battery using the response surface method. Met. Mater. Int. 2009, 15, 421-425.

(51) Perry, R. H.; Green, D. W., Eds. Perry's Chemical Engineers' Handbook; 7th ed.; McGraw-Hill, 1997.

(52) Liu, X.; Yu, L. Influence of nanosized $\mathrm{Ni}(\mathrm{OH}) 2$ addition on the electrochemical performance of nickel hydroxide electrode. J. Power Sources 2004, 128, 326-330.

(53) Okuno, K.; Kato, M.; Harada, K.; Park, J.-J.; Emura, K.; Yao, M.; Iwaki, T.; Tanase, S.; Sakai, T. Discharge Property of High Power Ni-MH Battery Using New Celmet. Sei Technical Review 2007, 64, 43 .

(54) Gille, G.; Albrecht, S.; Meese-Marktscheffel, J.; Olbrich, A.; Schrumpf, F. Cathode materials for rechargeable batteries-preparation, structure-property relationships and performance. Solid State Ionics 2002, 148, 269-282.

(55) Lide, D. R., Ed. CRC Handbook of Chemistry and Physics; 90th ed.; CRC Press/Taylor and Francis: Boca Raton, FL., 2009.

(56) Soria, M. L.; Chacón, J.; Hernandez, J. C. Metal hydride electrodes and Ni/MH batteries for automotive high power applications. J. Power Sources 2001, 102, 97-104.

(57) Xu, S. M.; Wu, F.; Li, L. Y.; Chen, S. Z.; Xu, J. M.; Xu, G. Recovery of valuable metals from anode material of hydrogen-nickel battery. Trans. Nonferrous Met. Soc. China 2009, 19, 468473.

(58) Zhou, H.; Zhou, Z. Preparation, structure and electrochemical performances of nanosized cathode active material $\mathrm{Ni}(\mathrm{OH})$. Solid State Ionics 2005, 176, 1909-1914.

(59) Liu, P. S.; Liang, K. M. Preparation and corresponding structure of nickel foam. Mater. Sci. Technol. 2000, 16, 575-578.

(60) Classen, M.; Althaus, H.-J.; Blaser, S.; Scharnhorst, W.; Tuchschmid, M.; Jungbluth, N.; Emmenegger, M. F. Life Cycle Inventories of Metals. Ecoinvent v2.0 Reports; Dübendorf, 2007; Vol. 10. 
(61) Cohrt, H.; Enders, M. Sintered Steel and Iron; In Ullmann's Encyclopedia of Industrial Chemistry; Wiley-VCH Verlag GmbH \& Co. KGaA: Weinheim, Germany, 2000.

(62) New Nickel Foam Plant in China a Boost to its Battery Industry. Green Car Congress Website. http://www.greencarcongress.com/2005/07/new_nickel_foam.html [Accessed May 30, 2010].

(63) Bauerlein, P.; Antonius, C.; Loffler, J.; Kumpers, J. Progress in high-power nickel-metal hydride batteries. J. Power Sources 2008, 176, 547-554.

(64) Microporous membranes; Celgard Polypore International Inc. Charlotte, 2008; Vol. 1996.

(65) Lascelles, K.; Morgan, L. G.; Nicholls, D.; Beyersmann, D. Nickel Compounds; In Ullmann's Encyclopedia of Industrial Chemistry; Wiley-VCH Verlag GmbH \& Co. KGaA: Weinheim, Germany, 2005; p. 16.

(66) Donaldson, J. D.; Beyersmann, D. Cobalt and Cobalt Compounds; In Ullmann's Encyclopedia of Industrial Chemistry; Wiley-VCH Verlag GmbH \& Co. KGaA: Weinheim, Germany, 2005; p. 35 .

(67) Kerfoot, D. G. E. Nickel; In Ullmann's Encyclopedia of Industrial Chemistry; Wiley-VCH Verlag GmbH \& Co. KGaA: Weinheim, Germany, 2000.

(68) Hischier, R. Life Cycle Inventories of Packagings and Graphical Papers. Packaging glass. Ecoinvent Reports; Dübendorf, 2007; Vol. 11.

(69) Wellbeloved, D. B.; Craven, P. M.; Waudby, J. W. Manganese and Manganese Alloys; In Ullmann's Encyclopedia of Industrial Chemistry; Wiley-VCH Verlag GmbH \& Co. KGaA: Weinheim, Germany, 2000.

(70) Zhang, W.; Cheng, C. Manganese metallurgy review. Part I: Leaching of ores/secondary materials and recovery of electrolytic/chemical manganese dioxide. Hydrometallurgy 2007, 89, 137-159.

(71) Samaras, C.; Meisterling, K. Life Cycle Assessment of Greenhouse Gas Emissions from Plug-in Hybrid Vehicles: Implications for Policy. Environ. Sci. Technol. 2008, 42, 3170-3176.

(72) Almemark, M.; Granath, J.; Setterwall, C. El för fordon -- Komparativ livscykelanalys för el- och förbränningsmotordrivna fordon under svenska förhållanden [Swedish] (Electricity for vehicles -- comparative life cycle assessment for electric and internal combustion vehicles for Swedish conditions; Elforsk: Stockholm, 1999; Vol. 99:30.

(73) Notter, D. A.; Gauch, M.; Widmer, R.; Wäger, P.; Stamp, A.; Zah, R.; Althaus, H.-J. Contribution of Li-ion batteries to the environmental impact of electric vehicles. Environ. Sci. Technol. 2010, $44,6550-6$.

(74) Rantik, M. Life Cycle Assessment of Five Batteries for Electric Vehicles under Different Charging Regimes; Chalmers University of Technology: Stockholm, 1999; Vol. 28.

(75) Annual Report 2009; Saft SA: Bagnolet, France, 2009.

(76) Environmental report; Hitachi Maxell Ltd: Osaka, 2004. 
(77) Rydh, C. J. Environmental Assessment of Battery Systems: Critical Issues for Established and Emerging Technologies, PhD Thesis, Chalmers University of Technology: Göteborg, 2003.

(78) Rydh, C. J.; Sun, M. Life cycle inventory data for materials grouped according to environmental and material properties. J. Cleaner Prod. 2005, 13, 1258-1268.

(79) Rydh, C. J. Environmental assessment of vanadium redox and lead-acid batteries for stationary energy storage. J. Power Sources 1999, 80, 21-29.

(80) Rydh, C. J.; Karlström, M. Life cycle inventory of recycling portable nickel-cadmium batteries. Resour., Conserv. Recycl. 2002, 34, 289-309. 